\title{
A VADLÚD MONITORING EREDMÉNYEI A 2013/2014-ES IDÉNYBEN MAGYARORSZÁGON
}

\author{
RESULTS OF GEESE MONITORING IN HUNGARY IN THE SEASON 2013/2014
}

\begin{abstract}
Dr. Faragó Sándor
Magyar Vízivad Kutató Csoport, Nyugat-magyarországi Egyetem Vadgazdálkodási és Gerinces Állattani Intézet Hungarian Waterfowl Research Group, Institute of Wildlife Management and Vertebrate Zoology,

University of West-Hungary

H-9400 Sopron, Ady Endre u. 5., Hungary
\end{abstract}

\section{BEVEZETÉS}

Jelen dolgozat folytatása mindazoknak a közléseknek, amelyek korábban, a libák állományváltozását mutatták be Magyarországon (STERBETZ, 1976; STERBETZ, 1983; FARAGÓ et al., 1991; FARAGÓ, 1995; FARAGÓ 1996, FARAGÓ \& JÁNOSKA, 1996, FARAGÓ, 1998; FARAGÓ, 1999; FARAGÓ, 2001; FARAGÓ, 2002a; FARAGÓ, 2002b; FARAGÓ \& GOSZTONYI, 2003; FARAGÓ, 2005; FARAGÓ, 2006; FARAGÓ, 2007a; FARAGÓ, 2007b; FARAGÓ, 2008; FARAGÓ, 2010a; FARAGÓ, 2010b; FARAGÓ, 2011a; FARAGÓ, 2011b; FARAGÓ, 2012; FARAGÓ, 2014).

\section{ANYAG ÉS MÓDSZER}

\subsection{Felmérések}

A felmérések módszerei megegyeznek az 1984-től folyamatosan végzett vadlúd monitoring eddigi közlései során (FARAGÓ, 1995; 1996, FARAGÓ \& JÁNOSKA, 1996, FARAGÓ, 1998; 1999; 2001; 2002a; 2002b; FARAGÓ \& GOSZTONYI, 2003; FARAGÓ, 2005; 2006; 2007a; 2007b; FARAGÓ, 2008; FARAGÓ, 2010a; FARAGÓ, 2010b; FARAGÓ, 2011a; FARAGÓ, 2011b; FARAGÓ, 2012; FARAGÓ, 2014) bemutatottakkal. A megfigyelési helyeket, valamint a megfigyeléseket koordinálók nevét az 1. táblázat mutatja.

1.táblázat: A Magyar Vadlúd Monitoring megfigyelési helyei és megfigyelői, 2013/2014.

Table 1: Sites of Hungarian Geese Monitoring in 2013/2014

\begin{tabular}{|l|l|l|l|}
\hline NO & MONITORING TERÜLETEK & SITES OF GEESE MONITORING & MEGFIGYELÖ/OBSERV \\
\hline 1. & Fertö - tó & Lake Fertő & Dr. Faragó, S \\
\hline 2. & Kis-Balaton & Kisbalaton & Dr. Nagy, L. (koord.) \\
\hline 3. & Balaton, Keszthelyi - öböl & Lake Balaton-West & Dr. Nagy, L. (koord.) \\
\hline 4. & Kelet - Balaton & Lake Balaton - East & Jakus, L \\
\hline 5. & Tatai Öreg - tó & Old Lake at Tata & Musicz, L \\
\hline 6. & Velencei - tó és Dinnyési Fertő & Lake Velence and Dinnyési Fertő & Fenyvesi, L \\
\hline 7. & Soponyai - halastavak & Fishponds at Soponya & Staudinger, I \\
\hline 8. & Rétszilasi - halastavak & Fishponds at Rétszilas & Staudinger, I \\
\hline 9. & Dráva Barcs-Szentborbás & River Dráva between Barcs and Szentborbás & Fenyősi, L \\
\hline 10. & Pellérdi - halastavak & Fishponds at Pellérd & Wágner, L. \\
\hline 11. & Sumonyi - halstavak & Fishponds at Sumony & Ónodi, M \\
\hline 12. & Duna Gönyü - Szob & River Danube between Gönyü and Szob & Dr. Faragó, S \\
\hline 13. & Duna Gemenc & River Danube at Gemenc & Mézes, G. \\
\hline 14. & Duna Karapancsa & River Danube at Karapancsa & Badari, T. \\
\hline 15. & Kiskunsági szikes tavak & Natron Lakes in Kiskunság & Bankovics, A. \\
\hline 16. & Tömörkényi Csaj - tó & Lake Csaj at Tömörkény & Domján, A \\
\hline 17. & Szegedi Fehér - tó és Fertő & Lake Fehér and Fertő at Szeged & Tokody, B. \\
\hline 18. & Tisza - tó & Lake Tisza & Gál, L. \\
\hline 19. & Hortobágy & Hortobágy & Dr. Végvári, Zs. \\
\hline 20. & Biharugrai és Begécsi halastavak & Fishponds at Biharugra and Begécs & Tögye, J \\
\hline 21. & Kardoskúti Fehér - tó & Lake Fehér at Karsdoskút & Széll, A \\
\hline
\end{tabular}


A vizsgálatok 2013 augusztusa és 2014 áprilisa közötti 9 hónapban, havi egy észleléssel folytak, amelyek időpontja az adott hónap 15-éjéhez legközelebbi hétvége volt. A fö megfigyelőnap a szombat, a megfigyelés szempontjából kedvezőtlen időjárás esetén a tartalék nap a vasárnap volt. A szinkronnapok az alábbiak voltak: 2013. augusztus 17, szeptember 14, október 19, november 16, december 14, 2014. január 18, február 15, március 15 és április 19.

\subsection{Feldolgozás}

A megfigyelési helyenként, havonként és fajonként gyüjtött alapadatokat a 3-30. táblázatok tartalmazzák abszolút (pd) és dominancia (\%) értékekben egyaránt. Ugyanezen táblázatok mutatják a libafajok magyarországi összes mennyiségének havi alakulását is.

A feldolgozás során fajonként értékeljük a megfigyeléseket, majd pedig a dominanciaviszonyok és az összes vadlúd példányszám alapján az összesített adatokat elemezzük. A 2013/2014-es eredményeket beleillesztjük a tartamos megfigyelések (long-term monitoring) adatsorába és meghatározzuk az aktuális tendenciákat. Végül pedig az adott szezon eredményei alapján értékeljük az egyes monitoring területek jelentőségét nemzetközi kritériumok alapján. Az értékelés alapja az ún. Ramsari 6. kritérium, amelynek értelmében nemzetközi jelentőségünek kell tekintetünk minden olyan területet, ahol egy faj, alfaj, populáció vagy részpopuláció állományának 1\%-a előfordul. Az erre vonatkozó legújabb számadatok a WETLANDS INTERNATIONAL (2015) közléséből származnak (2. táblázat).

2. táblázat: Vadlúd fajok Magyarországot érintő fészkelő vagy telelő populációinak nagysága, a Ramsari 6 kritérium 1\%-os szintje és az állományváltozás trendje (WETLANDS INTERNATIONAL, 2015)

Table 2: 1\% Ramsar Convention criterion 6 of geese species (WETLANDS INTERNATIONAL, 2015)

\begin{tabular}{|l|c|c|c|c|}
\hline \multicolumn{1}{|c|}{ Faj } & Populáció & $\begin{array}{c}\text { Állomány- } \\
\text { nagyság (pd) }\end{array}$ & $\begin{array}{c}\text { Ramsari 6 } \\
\text { kritérium } \\
\mathbf{1 \%}\end{array}$ & Trend \\
\hline Anser fabalis & közép és DNy-európai (telelö) & 550000 & $5500^{*}$ & stabil \\
\hline Anser brachyrhynchus & nyugat-európai (telelö) & 63000 & $630^{*}$ & növekvö \\
\hline Anser albifrons & közép-európai (telelö) & 110000 & $1100^{*}$ & növekvö \\
\hline Anser erythropus & DK-európai, Kaszpi-t. (telelö) & $60-80$ & $1 *(!)$ & csökkenö \\
\hline Anser anser & közép-európai (költö) & 56000 & $560^{*}$ & növekvö \\
\hline Branta leucopsis & Németország, Hollandia (telelö) & 770000 & $7700^{*}$ & növekvö \\
\hline Branta bernicla & nyugat-európai (telelö) & $200000-280000$ & $2400^{*}$ & csökkenö \\
\hline Branta ruficollis & fekete tengeri (telelö) & 44000 & $440^{*}$ & csökkenő \\
\hline
\end{tabular}

*: populáció szintű kritérium - criterion on population level

\section{EREDMÉNYEK}

\subsection{Vetési lúd (Anser fabalis)}

A vetési lúd magyarországi vonuló és telelő állománya decemberben 6630 pd-nyal tetőzött (1. ábra). Ez a mennyiség 26\%-kal kevesebb volt a 2012/2013-as idényben számolt legmagasabb értéknél (8999 pd) (3. ábra).

Az egyes megfigyelési helyeken tapasztalt dinamika (22. táblázat, 2. ábra) és a faj tér-idő mintázata (1. térkép) azt mutatja, hogy nagyobb számban - a korábbi évekhez hasonlóan - kizárólag a Dunántúlon lehetett megfigyelni. 
Legnagyobb példányszámban a vizsgált szezonban a Tatai Öreg-tónál észleltük (dec.: 6000 pd). Legalább 500 példányt csak a Duna Gemenci szakaszán becsültünk (jan.: 500 pd; febr.: $500 \mathrm{pd})$.

Az alföldi maximuma - Kiskunsági szikes tavak (ápr.: 13 pd), - tavasz végére esett, de a tetőzés mértéke még a korábban tapasztalt szerény példányszámokat is alulmúlta.

Az Anser fabalis rossicus alfaj állománynagyságát a legújabb közlés 550000 pd-ban adták meg (WeTLANDS InTERNATIONAL, 2015). Az 5500 pd-os - a teljes állomány 1\%-át (Ramsari 6. Kritérium) kitevő - a nemzetközi jelentőséget meghatározó szintjét a 2013/2014es szezonban csak a Tatai Öreg-tó (dec.: 6000 pd) érte el.

\subsection{Nagy lilik (Anser albifrons rossicus)}

A nagy lilik magyarországi telelő állománya a 2013/2014-es idényben, novemberben 138862 pd-nyal tetőzött (4. ábra), ami 11\%-kal kevesebb volt a 2012/2013-as idényben számlált legmagasabb (156 219 pd) értéknél (6. ábra).

Az egyes megfigyelési helyeken tapasztalt dinamika (23. táblázat, 5. ábra) és a faj tér-idő mintázata (2. térkép) azt mutatja, hogy a 2013/2014-es idényben ismételten a dunántúli előfordulások voltak a hangsúlyosabbak, bár az Alföldön, föleg a Tiszántúlon is nagy mennyiségek fordultak meg. Legfontosabb előfordulási helyének e vizsgálati szezonban a Tatai Öreg-tavat kell tartanunk, ahol a tetőző decemberi mennyiség a legmagasabb volt az országban - 46500 példánnyal (nov.: 19800 pd; jan.: 13400 pd). Harmincezer példány feletti mennyiség tetőzött a Velencei-tónál és a Dinnyési Fertőnél (jan.: 38400 pd; nov.: 27800 pd; dec.: 18300 pd) és a Hortobágyon (febr.: 33150 pd; nov.: 22910 pd; jan.: 22660 pd). Húszezer példánynál nagyobb mennyiségben kulminált a Kiskunsági szikes tavaknál (nov.: 22900 pd) és a Biharugrai- és Begécsi-halastavaknál (dec.: 21900 pd; febr.: 21800 pd). Tízezer példány feletti nagyságrendet tudtunk kimutatni a Fertő-tónál (dec.: 15334 pd; febr.: 11 142) is.

A WetLands InTERnational (2015) szerint a faj közép-európai, ún. Pannon, telelő populációjának nagysága 110000 pd és növekvő tendenciát mutat. Az állomány 1\%-át (Ramsari 6. Kritérium) kitevő 1100 pd-os értéket a 2013/2014-es idényben a 21 monitoring területünkböl 14 haladta meg, s ezáltal nemzetközi jelentöségünek volt tekinthetö.

\subsection{Kis lilik (Anser erythropus)}

A kis lilik magyarországi vonuló állománya februárban 61 pd-nyal tetőzött (7. ábra). Ez a mennyiség 54 példánnyal (több mint nyolcszor) nagyobb volt a 2012/2013-as (7 pd) legnagyobb egyedszámnál (8. ábra).

2 pd-t vagy annál nagyobb számú megfigyelést (24. táblázat, 3. térkép) a Fertő-tónál (febr.: 60 pd; jan.: 20 pd), a Tatai Öreg-tónál (nov.: 4 pd; dec.: 2 pd), a Biharugrai és Begécsihalastavaknál (nov.: 4 pd), valamint a Soponyai-halastavaknál (dec.: 2 pd) tettünk. Mindössze 1-1 pd-t észleltünk a Duna Gemenci szakaszán (jan.: 1 pd; febr.: 1 pd), a Duna karapancsai szakaszán (dec.: 1 pd) és a Tömörkényi Csaj-tónál (márc.: 1 pd).

A globálisan veszélyeztetett faj DK-európai és Kaszpi-tengeri telelő állománya 60-80 pd (WETLANDS INTERNATIONAL, 2015), amelynek 1\%-át kitevő - nemzetközi jelentőséget meghatározó - Ramsari 6. kritériumszintet, az 1 pd-t (!) a kis lilik hazánkban, a 2013/2014es idényben a Fertő-tónál, a Tatai Öreg-tónál, a Biharugrai és Begécsi-halastavaknál, a Soponyai-halastavaknál, a Duna Gemenci szakaszán, a Duna Karapancsai szakaszán és a Tömörkényi Csaj-tónál érte el. 


\subsection{Nyári lúd (Anser anser)}

A nyári lúd magyarországi vonuló és telelő állománya októberben 35573 pd-nyal tetőzött (9. ábra), ami 29\%-kal kevesebb volt a 2012/2013-as (49 919 pd) maximális értéknél (11. ábra).

Az egyes megfigyelési helyeken tapasztalt dinamika (25. táblázat, 10. ábra) és a faj tér-idő mintázata (4. térkép) azt mutatja, hogy a nyári lúd összességében kicsivel nagyobb számban a Dunántúlon jelent meg, de az abszolút maximumot (okt.: 14380 pd) a Hortobágyon regisztráltuk. Az $\mathbf{5 0 0 0}$ pd-t meghaladó mennyiséget a Kis-Balatonnál (okt.: 6429 pd) és a Fertő-tónál (dec.: 6318 pd) tudtunk számlálni.

Közép-európai fészkelő állományának nagysága növekvő, 56000 pd. Az 560 pd-os a közép-európai fészkelő állománynagyság 1\%-át kitevő - nemzetközi jelentőséget meghatározó, szintet (WETLANDS INTERNATIONAL, 2015), a 2013/2014-es idényben a 21 monitoring területünkböl 10 érte el.

\subsection{Kanadai lúd (Branta canadensis)}

A faj egyetlen példányát a Soponyai-halastavaknál figyelték meg a monitoring keretében 2014 januárjában (26. táblázat, 5. térkép). A faj korábban nem fordult elő a monitoring keretében.

\subsection{Apácalúd (Branta leucopsis)}

Az apácalúdnak a MAGYAR VADLÚD MONITORING szinkron számlálásai keretében a 2013/2014-es szezonban nyolc megfigyelése adódott. Maximális havi létszáma 4 pd volt (12. ábra). Előző idényben, a Monitoring keretében maximum 6 pd-át mutattuk ki (13. ábra).

A területi diszperzió 6 egységet érintett (27. táblázat), ezek rendre a Fertő-tó (febr.: 2 pd), a Kis-Balaton (dec.: 1 pd), a Tatai Öreg-tó (dec.: 1 pd; jan.: 1 pd), a Velencei-tó és Dinnyési Fertő (nov.: 2 pd; dec.: 2 pd), a Tömörkényi Csaj-tó (márc.: 3 pd) és a Hortobágy (okt.: 1 pd) (6. térkép).

A faj nyugat-európai telelő populációját 770000 pd-ra teszik, növekvő állománynagyság mellett (WETLANDS INTERNATIONAL, 2015). A Ramsari 6. kritérium 1\%-OS, a nemzetközi jelentőséget meghatározó szintje 7700 pd, amit egy területünk sem ért el.

\section{7. Örvös lúd (Branta bernicla)}

Az örvös lúdnak a MAGYAR VADLÚD MONITORING szinkron számlálásai keretében a 2013/2014-es szezonban hat megfigyelése adódott, maximális létszáma 2 pd volt (14. ábra). A Monitoring keretében a megelőző 2012/2013-as szezonban 3 pd-át (max. 1 pd) észleltük (15. ábra).

A területi diszperzió öt egységet érintett (28. táblázat), a Velencei-tónál és a Dinnyési Fertőn (nov.: 2 pd), a Soponyai-halastavaknál (jan.: 1 pd), a Duna Gemenci szakaszánál (Jan.: 1 pd; febr.: 1 pd), a Duna Karapancsai szakaszánál (okt.: 1 pd), továbbá a Kiskunsági szikes tavaknál (okt.: 1 pd) voltak megfigyelhetők (7. térkép).

A faj nyugat-európai telelő populációját 200 000-280 000 pd-ra teszik, csökkenő állománynagyság mellett (WETLANDS INTERNATIONAL, 2015). A Ramsari 6. kritérium 1\%-os, a nemzetközi jelentőséget meghatározó szintje 2400 pd, amit egy területünk sem ért el. 


\subsection{Vörösnyakú lúd (Branta ruficollis)}

A vörösnyakú lúdnak a MAGYAR VADLÚD MONITORING szinkron számlálásai keretében a 2013/2014-es szezonban ismételten rendszeres, újfent nagyobb egyedszámú megfigyelése adódott. A 139 pd-os érték (16. ábra) 3,5-szerese volt a 2012/2013-as 40 pd-os mélypontnak, s megközelítette a 2011/2012-es 177 pd-os kulmináló mennyiséget (17. ábra).

A területi diszperzió 10 egységet érintett (29. táblázat), ezek rendre: a Fertő-tó (dec.: 6 pd; jan.: 1 pd), a Tatai Öreg-tó (nov.: 24 pd; dec.: 10 pd; jan.: 6 pd), a Velencei-tó és Dinnyési Fertő (nov.: 14 pd; dec.: 3 pd; jan.: 11 pd; febr.: 16 pd), a Soponyai-halastavak (nov.: 3 pd; dec.: 3 pd; jan.: 1 pd), a Rétszilasi-halastavak (nov.: 1 pd), a Kiskunsági Szikestavak (nov.: 5 pd), a Tömörkényi Csaj-tó (nov.: 8 pd; dec.: 3 pd; márc.: 9 pd), a Tisza-tó (okt.: 1 pd), a Hortobágy (okt.: 1 pd; dec.: 9 pd; jan.: 113 pd; febr.: 75 pd; márc.: 50 pd), valamint a Biharugrai- és Begécsi-halastavak (nov.: 31 pd; dec.: 8 pd; jan.: 7 pd; febr.: 12 pd) (8. térkép).

A globálisan veszélyeztetett faj világállományát a legújabb közlések 44000 pd-ra teszik, növekvő állománynagyság mellett (WETLANDS INTERNATIONAL, 2015). A Ramsari 6. kritérium 1\%-os, a nemzetközi jelentőséget meghatározó szintje 440 pd, amit 2013/2014-ben egy területünk sem ért el.

\subsection{Nílusi lúd (Alopochen aegyptiaca)}

A faj mindeddig nem fordult elő a Magyar Vízivad Monitorig észlelései során. Első megfigyelése - $\mathbf{4}$ pd-nyal - 2013 októberében a Pellérdi-halastavaknál történt (30. táblázat; 9. térkép). Terjeszkedő faj, megfigyelésének faunisztikai jelentősége van.

\subsection{Vadludak összesített egyedszáma és dominanciája}

A mennyiségi értékelés során megállapítható volt, hogy a 2013/2014-es idényben, a Magyarországon átvonuló és telelő vadlibák összes állományának 164881 pd-os tetőzése novemberre esett (18. ábra). Ez az érték 10\%-kal kisebb volt a 2012/2013-as mennyiségnél (184 101) (20. ábra).

Az egyes megfigyelési helyeken tapasztalt dinamika (31. táblázat, 19. ábra) azt mutatta, hogy legnagyobb számban vadlibákat a Tatai Öreg-tónál (nov.: 21998 pd; dec.: 53013 pd; jan.: 15547 pd) lehetett megfigyelni.

Legfontosabb vadlúd előfordulási helyeknek a vizsgált szezonban az említetten kívül az alábbiakat kell tartanunk:

30 000-40 000 pd között tetőzött a libák létszáma - legalább egy esetben - a Velencei-tónál és Dinnyési Fertőnél (nov.: 29614 pd; dec.: 19435 pd; jan.: 38948 pd) és a Hortobágyon (okt.: 16614 pd; nov.: 24589 pd; dec.: 8487 pd; jan.: 23575 pd; febr.: 35239 pd; febr.: $14822 \mathrm{pd})$.

20 000-30 000 pd közötti maximális példányszámot észleltünk a Fertő-tónál (dec.: 21761 pd), a Kiskunsági szikes tavaknál (nov.: 23234 pd), valamint a Biharugrai- és Begécsihalastavaknál (nov.: 21375 pd; dec.: 24198 pd; febr.: 24762 pd).

10 000-20 000 pd közötti mennyiséget számláltunk még - legalább egy alkalommal - a Rétszilasi-halastavaknál (nov.: 11721 pd).

Ha a mennyiségi paramétereken túl az egyes megfigyelési helyek, illetve az országos állományadatok dominancia viszonyait is elemezzük (3-31. táblázat; 21. ábra), akkor 
azoknak jellegét, illetőleg az egyes vadlúdfajok vonulásában/telelésében betöltött szerepét is kimutathatjuk.

Ha az egyes hónapokban érvényes, az országos állománynagyságra vonatkoztatott dominancia-viszonyokat elemezzük (32. táblázat és 22. ábra), akkor az egyedszámokkal összhangban, a 2013/2014-es idényben, a nagy lilik volt a legnagyobb példányszámban (138 862 pd) megjelent libafaj Magyarországon (max. 88\%), ezt követte a nyári lúd (35 573 pd, max. 95\%), majd a vetési lúd (6630 pd, max. 4\%). A globálisan veszélyeztetett kis lilik dominanciája $0-+\%$ között változott, abszolút értékének rendkívül alacsony (max. 61 pd) méretével.

\section{KÖVETKEZTETÉSEK}

A 2013/2014-es szezon adatait, ha beillesztjük a tartamos megfigyelések (long-term monitoring) sorába, következtetéseket vonhatunk le az aktuális állományváltozásról.

A vetési lúd tetőző állománya (6630 pd) alacsonyabb volt a 2012/2013-as idény során tapasztalt maximumnál (8999 pd), a csökkenés mértéke 26\%-os. Ha korábbi idények adatait nézzük, akkor a vetési lúd állománydinamikáját változatlan csökkenés és továbbra is bizonytalanság jellemzi a Pannon régióban.

A nagy lilik tetőző egyedszáma (138 862 pd) 11\%-kal kevesebb volt a 2012/2013-as idényben számlált maximumnál (156219 pd). Mindezen értékek alapján újfent megállapíthatjuk a telelő állomány regenerálódását, ami a megfigyelhető kisebb-nagyobb természetes fluktuáció mellett és ellenére, - óvatos optimizmussal - tartósan magas évenkénti tetőző létszámok jövőbeni megjelenésére enged következtetni.

A globálisan veszélyeztetett kis lilik magyarországi vonuló állománya februárban 61 pd-nyal tetőzött. Ez a mennyiség 54 pd-nyal több volt a 2012/2013-as (7 pd) egyedszámnál. Mindennek ellenére továbbra is tragikusan alacsony a faj tetőző egyedszáma.

A nyári lúd továbbra is magas (35 573 pd) - ugyan a megelőző évhez (49 919 pd) képest 29\%-kal alacsonyabb - létszámmal volt jelen a monitoring területeken.

A kanadai lúd (1 pd), az apácalúd (max. 4 pd), az örvös lúd (max. 2 pd) és a nílusi lúd (max. 4 pd) jelentéktelen példányszámai mellett, megemlítendő a vörösnyakú lúd újfent jelentősebb mennyisége (max. 139 pd).

Az egyes fajoknál észlelt dinamikák egyenlegeként, a 2013/2014-es szezonban, az egyidőben megfigyelt összes vadlúd maximális mennyisége (164 881 pd) 10\%-kal kevesebb volt a 2012/2013-as értéknél (184 101 pd).

\section{IRODALOMJEGYZÉK - REFERENCES}

FARAGÓ, S. (1995): Geese in Hungary 1986-1991. Numbers, Migration and Hunting Bags. IWRB Publication 36. 97 pp.

FARAGÓ, S. (1996): A Magyar Vadlúd Adatbázis 1984-1995: Egy tartamos monitoring (Data Base of Geese in Hungary 1984-1995: A long-term monitoring). Magyar Vízivad Közlemények - Hungarian Waterfowl Publications 2: 3-168.

FARAGÓ, S. (1998): A vadlúd monitoring eredményei az 1996/1997-es idényben Magyarországon (Results of Geese Monitoring in Hungary in the season 1996/1997). Magyar Vízivad Közlemények - Hungarian Waterfowl Publications 4: $17-60$. 
FARAGÓ, S. (1999): A vadlúd monitoring eredményei az 1997/1998-as idényben Magyarországon (Results of Geese Monitoring in Hungary in the season 1997/1998). Magyar Vízivad Közlemények - Hungarian Waterfowl Publications 5: 3-62.

FARAGó, S. (2001): A vadlúd monitoring eredményei az 1998/1999-es idényben Magyarországon (Results of Geese Monitoring in Hungary in the season 1998/1999). Magyar Vízivad Közlemények - Hungarian Waterfowl Publications 7: 3-40.

FARAGÓ, S. (2002a): A vadlúd monitoring eredményei az 1999/2000-es idényben Magyarországon (Results of Geese Monitoring in Hungary in the season 1999/2000). Magyar Vízivad Közlemények - Hungarian Waterfowl Publications 8: 3-43.

FARAGÓ, S. (2002b): A vadlúd monitoring eredményei a 2000/2001-es idényben Magyarországon (Results of Geese Monitoring in Hungary in the season 2000/2001). Magyar Vízivad Közlemények - Hungarian Waterfowl Publications 9: 3-45.

FARAGÓ, S. (2005): A vadlúd monitoring eredményei a 2002/2003-as idényben Magyarországon (Results of Geese Monitoring in Hungary in the season 2002/2003). Magyar Vízivad Közlemények - Hungarian Waterfowl Publications 12: $3-42$.

FARAGÓ, S. (2006): A vadlúd monitoring eredményei a 2003/2004-as idényben Magyarországon (Results of Geese Monitoring in Hungary in the season 2003/2004). Magyar Vízivad Közlemények - Hungarian Waterfowl Publications 13: 3-39.

FARAGÓ, S. (2007a): A vadlúd monitoring eredményei a 2004/2005-ös idényben Magyarországon (Results of Geese Monitoring in Hungary in the season 2004/2005). Magyar Vízivad Közlemények - Hungarian Waterfowl Publications 14: 3-39.

FARAGó, S. (2007b): A vadlúd monitoring eredményei a 2005/2006-os idényben Magyarországon (Results of Geese Monitoring in Hungary in the season 2005/2006). Magyar Vízivad Közlemények - Hungarian Waterfowl Publications 15: $3-45$.

FARAGÓ, S. (2008): A vadlúd monitoring eredményei a 2006/2007-es idényben Magyarországon (Results of Geese Monitoring in Hungary in the season 2006/2007). Magyar Vízivad Közlemények - Hungarian Waterfowl Publications 17: 3-42.

FARAGÓ, S. (2010a): A vadlúd monitoring eredményei a 2007/2008-as idényben Magyarországon (Results of Geese Monitoring in Hungary in the season 2007/2008). Magyar Vízivad Közlemények - Hungarian Waterfowl Publications 18-19: 3-42.

FARAGÓ, S. (2010b): A vadlúd monitoring eredményei a 2008/2009-es idényben Magyarországon (Results of Geese Monitoring in Hungary in the season 2008/2009). Magyar Vízivad Közlemények - Hungarian Waterfowl Publications 18-19: 221-258.

FARAGÓ, S. (2011a): A vadlúd monitoring eredményei a 2009/2010-es idényben Magyarországon (Results of Geese Monitoring in Hungary in the season 2009/2010). Magyar Vízivad Közlemények - Hungarian Waterfowl Publications 20-21: 3-41. 
FARAGÓ, S. (2011b): A vadlúd monitoring eredményei a 2010/2011-es idényben Magyarországon (Results of Geese Monitoring in Hungary in the season 2010/2011). Magyar Vízivad Közlemények - Hungarian Waterfowl Publications 20-21: 201-249.

FARAGÓ, S. (2012): A vadlúd monitoring eredményei a 2011/2012-es idényben Magyarországon (Results of Geese Monitoring in Hungary in the season 2011/2012). Magyar Vízivad Közlemények - Hungarian Waterfowl Publications 22: 3-50.

FARAGÓ, S. (2014): A Vadlúd Monitoring eredményei az 2012/2013-as idényben Magyarországon (Results of Geese Monitoring in Hungary in the season 2012/2013). Magyar Vízivad Közlemények 24: 3-49.

FARAGÓ, S. \& GoszTonyI, L. (2003): A Vadlúd Monitoring eredményei a 2001/2002-es idényben Magyarországon (Results of Geese Monitoring in Hungary in the season 2001/2002). Magyar Vízivad Közlemények - Hungarian Waterfowl Publications 11: 3-50.

FARAGÓ, S. \& JÁNOSKA, F. (1996): A Vadlúd Monitoring eredményei az 1995/1996-os idényben Magyarországon (Results of Geese Monitoring in Hungary in the season 1995/1996). Magyar Vízivad Közlemények - Hungarian Waterfowl Publications 2: 169-210.

FARAGÓ, S., KovÁCS, G. \& STERBETZ, I. (1991): Goose populations staging and wintering in Hungary 1984-1988. Ardea 79 (2): 161-164.

STERBETZ, I. (1976): Development of wild geese migration on the Hungarian gathering places. Aquila 82: 181-194.

STERBETZ, I. (1983): The trend of the migration of wild geese in Hungary in the period 19721982. Állattani Közlemények 70: 69-72.

WetLANDS InTERnATIONAL (2015): Waterbird Population Estimates. Wetlands International Wageningen, The Netherland, - online database 


\title{
RESULTS OF GEESE MONITORING IN HUNGARY IN THE SEASON 2013/2014
}

\author{
Dr. Faragó, S.
}

\section{SUMMARY}

The author presents the results of the Hungarian GeEse Monitoring (Table 1.) for 2013/2014 in the form of a data base. After reviewing the basic data recorded at each site of observation (Table 3-21.) he analyse the obtained data separately for each species, i.e. Bean Goose (Anser fabalis rossicus) (Table 22., Map 1., Figure 1-3.), White-fronted Goose (Anser albifrons) (Table 23., Map 2., Figure 4-6.), Lesser White-fronted Goose (Anser erythropus) (Table 24., Map 3., Figure 7-8.), Greylag Goose (Anser anser) (Table 25., Map 4., Figure 9-11.), Canada Goose (Branta canadensis) (Table 26., Map 5.), Barnacle Goose (Branta leucopsis) (Table 27., Map 6., Figure 12-13.), Brent Goose (Branta bernicla)(Table 28., Map 7., Figure 14-15.), Red-breasted Goose (Branta ruficollis) (Table 29, Map 8., Figure 16-17.), Egyptian Goose (Alopochen aegyptiaca) (Table 30., Map 9.), as well as for the total of observed geese (Table 31., Figure 18-20.).

In respect of dominance - when data recorded monthly in each of the observed sites (Table 3-21., Figure 21.) or those referring to the total of geese present in Hungary (Table 32., Figure 22.) are analysed, it is found that in conformity with the numbers of individuals, also in the season 2013/2014 White-fronted Goose was the most common goose species in Hungary (max. 138862 birds, max. 88\%), followed by Greylag Goose (max. 35573 birds, max. 95\%), Bean Goose (max. 6630 birds, max. 4\%) ranking third. Dominance of Lesser White-fronted Goose - a globally threatened species - ranged from $0 \%$ to $<1 \%$ (max. 61 birds).

If the data obtained for the season 2013/2014 are fitted into the data series of longterm monitoring, the following conclusions can be drawn from the actual changes in population numbers of the geese species in the Pannon region.

Peak number of Bean Goose (6630 birds) was lower as the maximum counted in the season 2012/2013 (8999 birds), decrements amounting to 26\%.

Peak numbers of White-fronted Goose (138 862 birds) was lower as the maximum counted in 2012/2013 (156 219birds), decrements amounting to 11\%.

For the globally threatened Lesser White-fronted Goose may be considered higher (61 birds) to the maximum counted in the season 2012/2013 (7 birds).

Greylag Goose continued to be present with high numbers in Hungary. However, in the new season its peaks (birds) were found to be lower (-29\%) those counted in the previous seasons (49 919 birds).

For the globally threatened Red breasted Goose may be considered much higher (139 birds) to the maximum counted in the season 2012/2013 (40 birds).

In the season 2013/2014 we observed max 1 Canada Goose, max 4 Barnacle Geese max 2 Brent Geese and max 4 Egyptian Geese.

The maximum numbers of total geese registered simultaneously (164 881 birds) by 10\% differed (lower) from those in the season 2012/2013 (184 101birds). 


\begin{tabular}{|c|c|c|c|c|c|c|c|}
\hline 窎 & $\stackrel{8}{-1}$ & & 0 & 10 & 0 & 0 & \\
\hline$\sum^{\pi}$ & 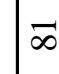 & $\sigma$ & 0 & 10 & 0 & 0 & \\
\hline 包 & $\stackrel{\Delta}{\Delta}$ & 这 & 0 & -1 & 10 & 0 & \\
\hline$\stackrel{\mathbb{7}}{\stackrel{7}{2}}$ & صِّ & $\infty$ & 0 & 10 & 10 & 0 & \\
\hline ڤ̆ & 2 & $尺$ & 0 & 0 & 0 & 0 & $£$ \\
\hline 吕 & $\approx$ & \pm & 0 & 10 & 0 & 0 & $£$ \\
\hline 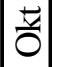 & 6 & $\approx \widetilde{n}$ & 0 & -1 & 0 & 0 & \\
\hline 苟 & $\stackrel{8}{\circ}$ & 0 & 0 & 0 & 0 & 0 & $\xi$ \\
\hline 至 & 8 & 0 & 0 & 0 & 10 & 0 & \\
\hline 氞 & \&ి & 0 & 0 & 0 & 0 & 0 & \\
\hline$\sum^{\pi}$ & $\underset{ }{\stackrel{Y}{O}}$ & 呙 & 0 & 10 & 0 & 0 & \\
\hline 总 & 容 & $\underset{\mathcal{Z}}{\mathcal{Z}}$ & 8 & $\stackrel{\infty}{\dddot{m}}$ & $\tau$ & 0 & \\
\hline$\underset{\sim}{\sim}$ & & 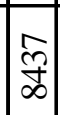 & $\curvearrowright$ & 0 & 0 & -1 & \\
\hline 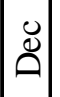 & $=\frac{\infty}{\bar{\gamma}}$ & 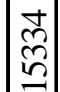 & 0 & $\stackrel{\rho}{0}$ & $a$ & 0 & \\
\hline z) & 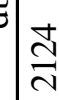 & $\underset{\mathbb{Z}}{\mathbb{Z}}$ & 0 & $\ddot{m}$ & 0 & 0 & \\
\hline ప্t) & 局 & ڤ̆ & 0 & $\stackrel{ }{\sim}$ & 0 & 0 & \\
\hline जे & 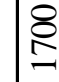 & 0 & 0 & 10 & 10 & 0 & \\
\hline 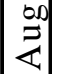 & $\underset{\sim}{\stackrel{N}{ }}$ & 0 & 0 & 0 & 0 & 0 & |c \\
\hline & 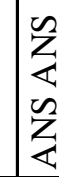 & 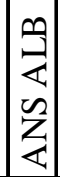 & 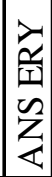 & 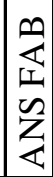 & n & $\begin{array}{l}\text { S } \\
\mathbb{2} \\
\mathbb{2}\end{array}$ & 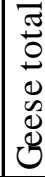 \\
\hline
\end{tabular}

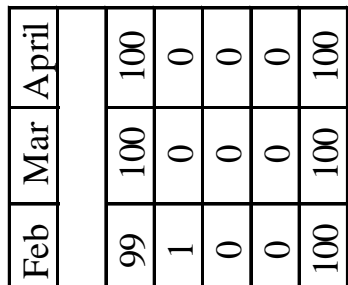

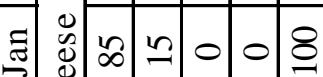

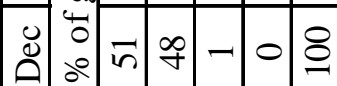

zे मी

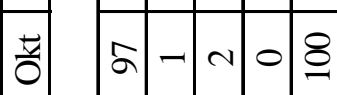

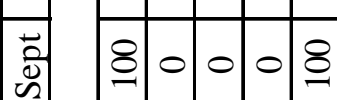

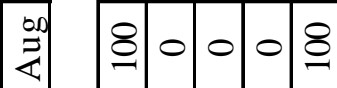

氮

\begin{tabular}{|l|l|l|l|}
\hline & & & \\
\hline
\end{tabular}

$\sum^{\pi}$ ก 00000

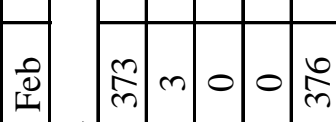

즌

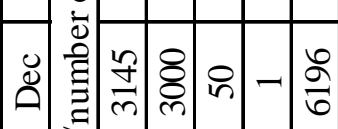

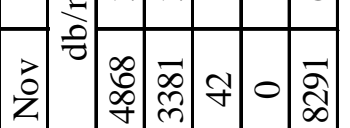

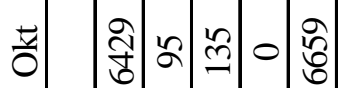

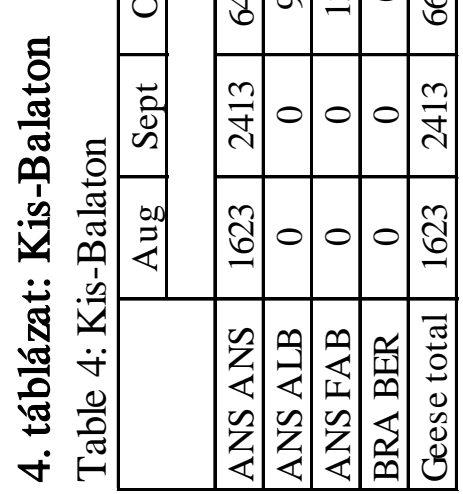

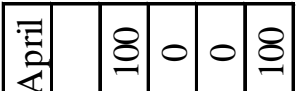

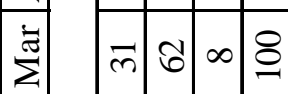

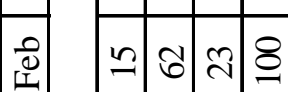

총

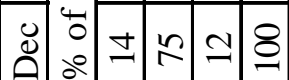

김

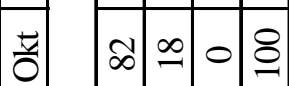

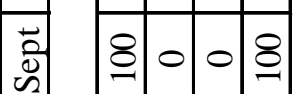

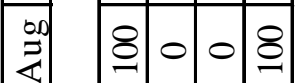

氞

\begin{tabular}{|l|l|l|l|}
\hline & & & \\
\hline & & &
\end{tabular}

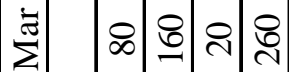

원 육웍워

츰

气ิ

$\rightarrow$ 하

$\overrightarrow{2}$

소여ํ 눙

홀

포

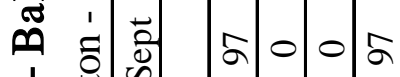

'

屯

头言至

ㄴ.

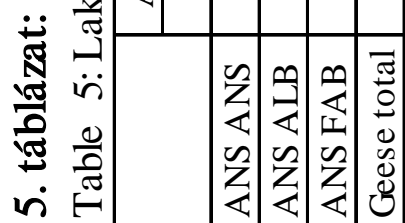




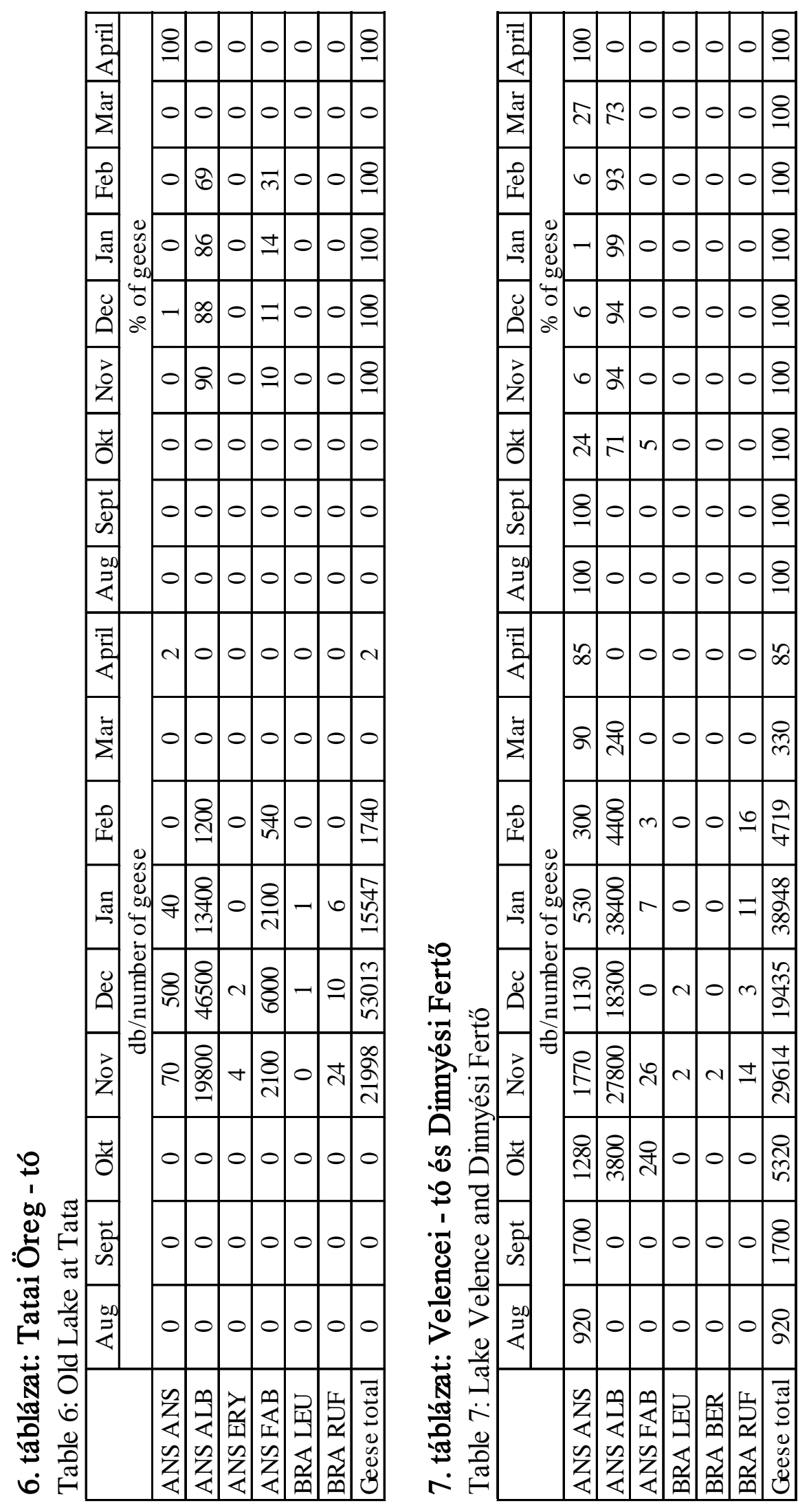




\begin{tabular}{|c|c|c|c|c|c|c|c|c|}
\hline & $\underset{-1}{\circ}$ & 0 & o & 0 & 0 & o & & 응 \\
\hline & $\infty$ & ชิ & 0 & 0 & 0 & 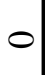 & 0 & 음 \\
\hline & $\infty$ & ๆ & 0 & 0 & 0 & o & 0 & 8 \\
\hline$: 5$ & $\hat{m}$ & 8 & 0 & 0 & 0 & o & 0 & $\underset{-}{8}$ \\
\hline & $\stackrel{\infty}{\sim}$ & $\nabla$ & 0 & 0 & 0 & 0 & 0 & \& \\
\hline & 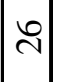 & 市 & 0 & 0 & 0 & o & 0 & 으 \\
\hline & $\infty$ & $m$ & 0 & 0 & 0 & 0 & 0 & $\underset{-}{8}$ \\
\hline & 8 & 0 & 0 & 0 & 0 & 0 & 0 & \& \\
\hline & $\underset{-1}{8}$ & 0 & 0 & 0 & 0 & 0 & 0 & 을 \\
\hline & g) & 0 & 0 & 0 & 0 & ol & 0 & 守 \\
\hline & $\vec{\nabla}$ & ग्र్సి & 0 & 0 & 0 & 0 & 0 & $\begin{array}{l}\mathscr{D} \\
\stackrel{\sim}{N}\end{array}$ \\
\hline & $\infty$ & 유 & 0 & 0 & 0 & 0 & 0 & $\stackrel{\infty}{=}$ \\
\hline & ஓे & $\begin{array}{l}\text { \&్ } \\
\stackrel{+}{-1}\end{array}$ & 0 & 0 & -1 & -1 & - & 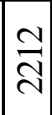 \\
\hline & ৪্ণ & 임 & $N$ & 0 & 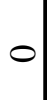 & 0 & $m$ & 낭 \\
\hline & 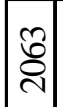 & ఫి & 0 & $\stackrel{\sim 0}{\longrightarrow}$ & 0 & 0 & $m$ & 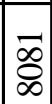 \\
\hline & $\begin{array}{l}\text { 吕 } \\
\text { p. } \\
\end{array}$ & ㅇํํ & 0 & 0 & 0 & 0 & 0 & \& \\
\hline & શิ) & 0 & 0 & 0 & 0 & 0 & 0 & $\underset{\exists}{\beth}$ \\
\hline & 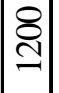 & 0 & 0 & 0 & 0 & 0 & & ¿্ণ \\
\hline & 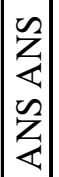 & 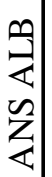 & 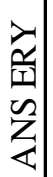 & 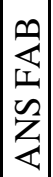 & 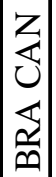 & 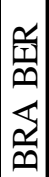 & 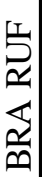 & 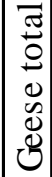 \\
\hline
\end{tabular}

\begin{tabular}{|c|c|c|c|c|}
\hline 㝴 & 역 & 0 & 0 & 음 \\
\hline$\stackrel{\pi}{\pi}$ & 욱 & 0 & 0 & $\underset{\sim}{\stackrel{\circ}{1}}$ \\
\hline & ब & a & 0 & $\underset{-}{8}$ \\
\hline 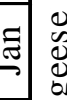 & $\stackrel{\imath}{\sim}$ & $\Sigma$ & 0 & 8 \\
\hline $\begin{array}{ll}0 \\
\stackrel{0}{0}\end{array}$ & $\infty$ & $\Xi$ & 0 & 음 \\
\hline 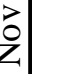 & లి & $\nabla$ & 0 & \& \\
\hline है & $\infty$ & $\Rightarrow$ & 0 & $\underset{-}{\stackrel{1}{1}}$ \\
\hline 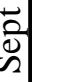 & ৪ి & 0 & 0 & $\underset{-1}{8}$ \\
\hline | & 익 & 0 & 0 & $\stackrel{-}{\circ}$ \\
\hline $\mathbb{1}$ & ले & 0 & 0 & $\stackrel{\text { Lq }}{\mathrm{m}}$ \\
\hline$\sum_{\Sigma}^{\pi}$ & $\frac{0}{m}$ & 0 & 0 & $\stackrel{\varphi}{m}$ \\
\hline 胥 & ฟิ & 요 & 0 & $\widehat{N}$ \\
\hline $\mathbb{Z}:$ & 곡 & ৪ి & 0 & 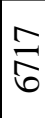 \\
\hline ڤે & ৪) & 익 & 0 & 옹 \\
\hline $\begin{array}{l}\text { 足 } \\
z\end{array}$ & \begin{tabular}{l}
$\stackrel{શ}{\vartheta}$ \\
\multirow{\gamma}{*}{}
\end{tabular} & 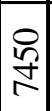 & -1 & $\underset{\mathcal{N}}{\vec{\Xi}}$ \\
\hline ప & 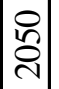 & ㅇํ․ & 0 & \&্লি \\
\hline 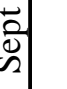 & 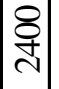 & 0 & 0 & i্ণ \\
\hline 资 & 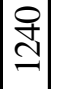 & 0 & 0 & 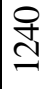 \\
\hline & 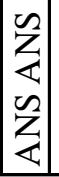 & 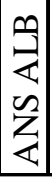 & 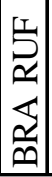 & 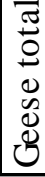 \\
\hline
\end{tabular}

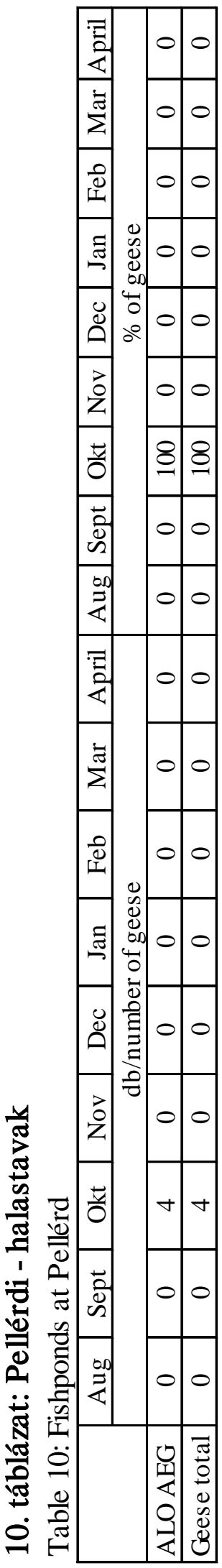




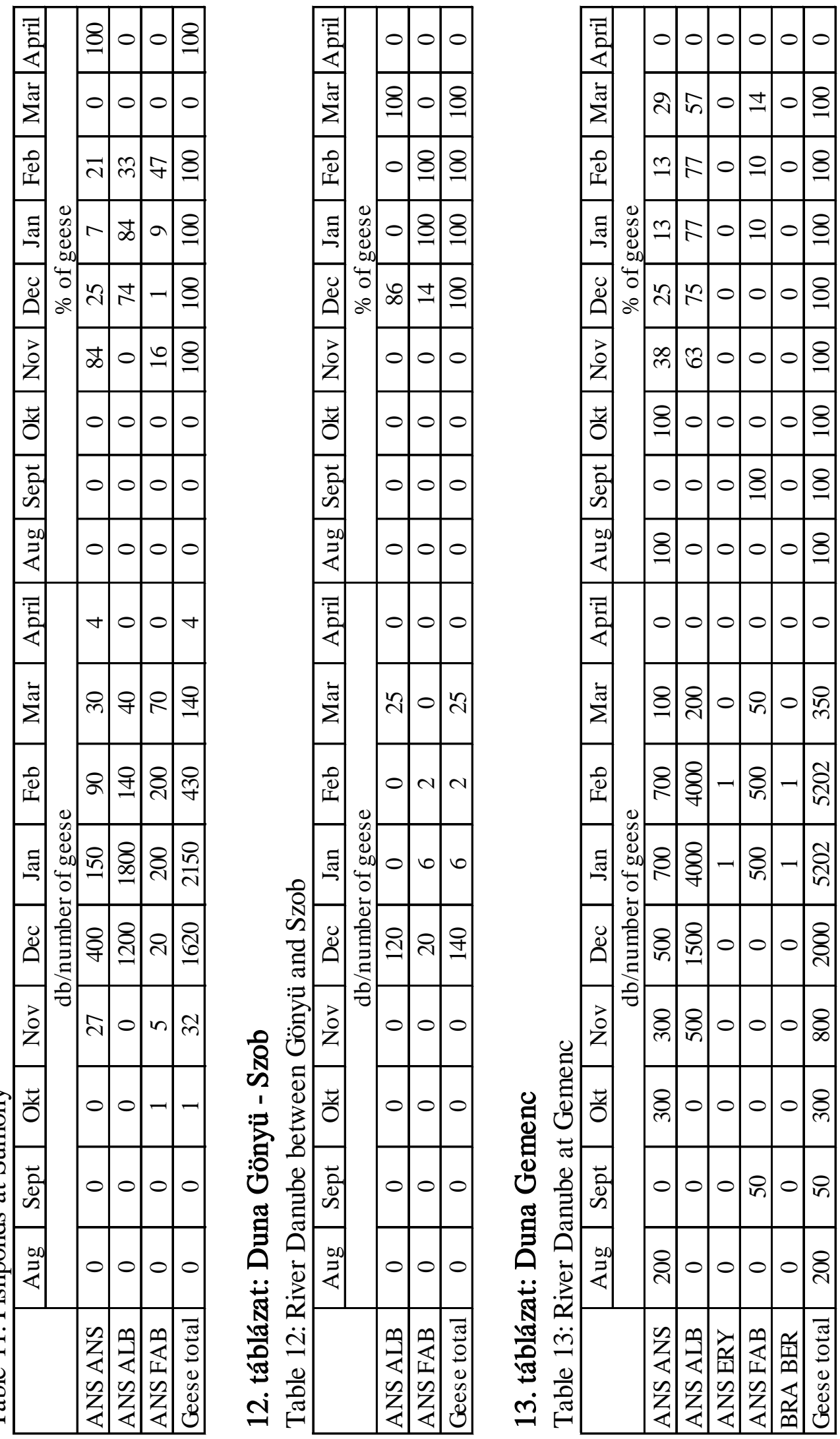




\begin{tabular}{|c|c|c|c|c|c|c|}
\hline 氞 & 8 & 0 & 0 & 0 & 0 & $\underset{-1}{8}$ \\
\hline$\sum^{\tilde{z}}$ & 穴 & $|\infty|$ & 0 & $\stackrel{\sim}{\sim}$ & 0 & 의 \\
\hline बे & 9 & ถิ & 0 & 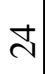 & 0 & 음 \\
\hline 疍 & 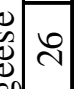 & $\mathscr{\gamma}$ & 0 & లి & 인 & 8 \\
\hline$\ddot{\Xi}$ & 0 & -1 & $N$ & $m$ & $\nabla$ & 0 \\
\hline 齐 & 8 & $\Rightarrow$ & 0 & $\curvearrowright$ & 0 & 8 \\
\hline 흥 & $\infty$ & $\nabla$ & 0 & 의 & 0 & 8 \\
\hline 苟 & ᄋ & 0 & 0 & 0 & 0 & 8 \\
\hline 唩 & 8 & 0 & 0 & 0 & 0 & 8 \\
\hline 㟃 & 옥 & 0 & 0 & 0 & 0 & 욤 \\
\hline$\sum_{i}^{\pi}$ & ৪) & $\stackrel{\overbrace{}}{二}$ & 0 & $\stackrel{8}{0}$ & 0 & $\not$ \\
\hline ه্ & ટ્ટ & 8 & 0 & ญ̊ & 0 & 옹 \\
\hline 龸 & 雚 & ○ి & 0 & 号 & 0 & 옥 \\
\hline$\stackrel{\cup}{0}$ & : & 욕 & -1 & 윴 & -1 & $\widehat{N}$ \\
\hline $\begin{array}{l}z \\
2 \\
z\end{array}$ & 得 & $尺$ & 0 & $\stackrel{\text { m}}{-1}$ & 0 & 앵 \\
\hline 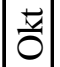 & 守 & ㄱ. & 0 & 오 & 0 & ิㅗ \\
\hline ڤे & 品 & 0 & 0 & 0 & 0 & 品 \\
\hline 夠 & : & 0 & 0 & 0 & 0 & ి.ల \\
\hline & $\mid \begin{array}{l}n \\
z \\
z \\
n \\
z \\
z\end{array}$ & 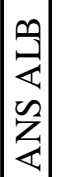 & 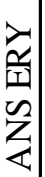 & 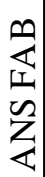 & 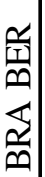 & 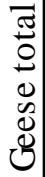 \\
\hline
\end{tabular}

\begin{tabular}{|c|c|c|c|c|c|c|}
\hline & 0 & ৪ & -1 & 0 & 0 & \\
\hline & 0 & চ & 0 & 0 & 0 & \\
\hline & 0 & চ & 0 & 0 & 0 & \\
\hline 配 & ठ & $\ddot{m}$ & 0 & 0 & 0 & \\
\hline & $\bar{m}$ & 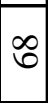 & 0 & 0 & 0 & $£$ \\
\hline & -1 & の & 0 & 0 & 0 & \\
\hline & $\mathscr{\infty}$ & $\sim$ & 0 & 0 & 0 & $\S$ \\
\hline & ৪ి & 0 & 0 & 0 & 0 & $\xi$ \\
\hline 呟 & \& & 0 & 0 & 0 & 0 & \\
\hline & 0 & ర్ర & 9 & 0 & 0 & 崖 \\
\hline$\sum^{\pi}$ & \begin{tabular}{l}
$\emptyset$ \\
\multirow{2}{*}{}
\end{tabular} & $\mid \begin{array}{l}\text { oे } \\
\text { ले }\end{array}$ & 0 & 0 & 0 & \\
\hline 勇 & 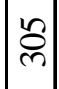 & 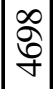 & 0 & 0 & 0 & \\
\hline & 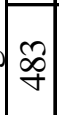 & ํㅗㄴ & & 0 & 0 & \\
\hline 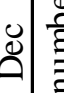 & $\vec{\Xi}$ & 守 & -1 & 0 & 0 & \\
\hline$a^{2}$ & ले & 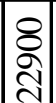 & 0 & 0 & L & 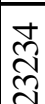 \\
\hline 范 & \begin{tabular}{|c}
0 \\
ษิ
\end{tabular} & 의 & 0 & -1 & 0 & 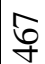 \\
\hline :े & ஓি & 10 & 0 & 0 & 0 & ल \\
\hline & 守 & 0 & 0 & 0 & 0 & 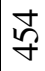 \\
\hline & 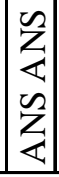 & 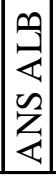 & 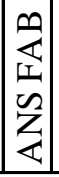 & 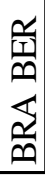 & 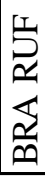 & 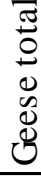 \\
\hline
\end{tabular}

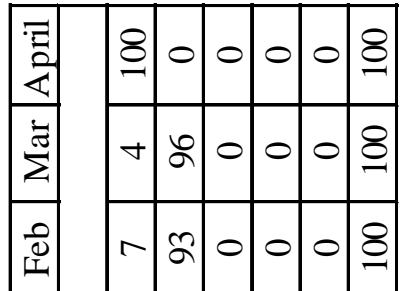

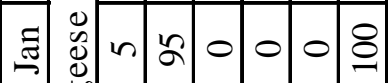

ดั

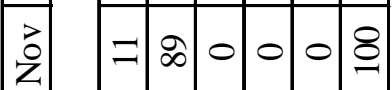

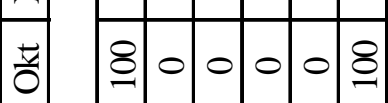

के

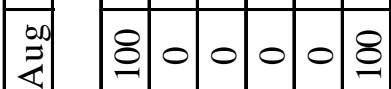

司

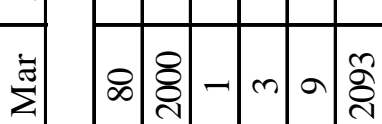

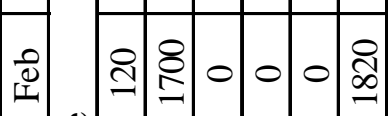

离

(

ดั

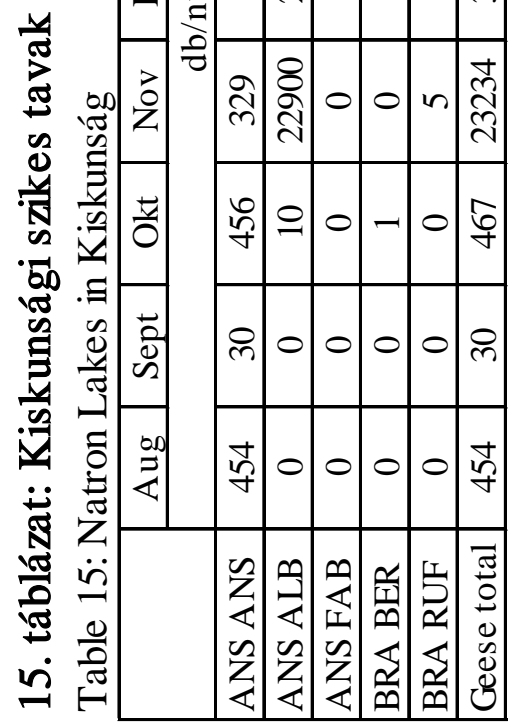




\begin{tabular}{|c|c|c|c|c|c|c|c|c|c|c|c|c|c|c|c|c|c|c|}
\hline & 氞 & 8 & 0 & $\underset{\sim}{8}$ & & 窎 & क & o & 0 & $\underset{ }{8}$ & & 窎 & $\forall$ & in & 10 & 0 & 0 & \& \\
\hline & $\sum^{\bar{\pi}}$ & 8 & 0 & \&) & & $\sum^{2}$ & 용 & 는 & 0 & 8 & & $\sum^{i}$ & $\approx$ & $\infty$ & 0 & 0 & 0 & \& \\
\hline & 包 & ถิำ & ซ & 영 & & $\mid \begin{array}{l}0 \\
0 \\
0\end{array}$ & 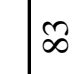 & $\approx$ & 0 & 8 & & $\left|\begin{array}{l}0 \\
0 \\
\underline{x}\end{array}\right|$ & 0 & চ & 10 & 0 & 0 & 욤 \\
\hline & 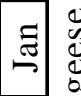 & $\infty$ & . & 웍 & & : & 苟 & 0 & 0 & 8 & & : & $m$ & $\mathscr{6}$ & 0 & 0 & 0 & 8 \\
\hline & 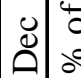 & 0 & 8 & \& & & $\stackrel{\mathscr{U}}{0}$ & 苟 & 0 & 0 & $\underset{ }{8}$ & & 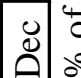 & 0 & के & 0 & 0 & 0 & $\stackrel{8}{\circ}$ \\
\hline & $\begin{array}{l}3 \\
2\end{array}$ & ษ & $\infty$ & 영 & & : & to & है & 0 & $\underset{-1}{8}$ & & $\begin{array}{l}3 \\
z \\
z\end{array}$ & $\Lambda$ & के & 10 & 0 & 0 & 8 \\
\hline & 봉 & - & 0 & 여 & & $\frac{t}{0}$ & $\widetilde{\sigma}$ & Dे & 0 & $\underset{-1}{8}$ & & $\frac{\pi}{0}$ & $\infty$ & 9 & 0 & 0 & 0 & $\underset{-}{8}$ \\
\hline & 苟 & ৪ & 0 & \& & & 苟 & 冓 & 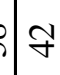 & 0 & $\underset{9}{8}$ & & 苟 & 의 & 0 & 0 & 0 & 0 & $\stackrel{8}{\circ}$ \\
\hline & 照 & 8 & 0 & \&్తి & & 焦 & $\underset{-}{\stackrel{1}{2}}$ & 0 & 0 & 8 & & 䏛 & 8 & 0 & 0 & 0 & 0 & \& \\
\hline & 氞 & $\mid$\begin{tabular}{l}
$\stackrel{0}{\infty}$ \\
\hdashline \\
$\sim$
\end{tabular} & 0 & 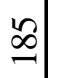 & & 㟃 & 8 & b & 0 & 웅 & & 韋 & 8 & ম্ণ & 0 & 0 & 0 & స్లై \\
\hline & $\sum^{\pi}$ & 8 & 0 & 8 & & $\sum^{\tilde{\pi}}$ & ৪্ & 官 & 0 & త্ণ & & $\stackrel{\tilde{\pi}}{\Sigma}$ & 寺 & ठ্. & 0 & 0 & in & స్ \\
\hline & 离 & $\tilde{్ ర ి}$ & $\stackrel{\Omega}{\widehat{N}}$ & 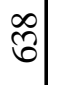 & & 竞 & ৪ & ) & 0 & \& & & $\mid \begin{array}{l}0 \\
0 \\
0\end{array}$ & $\vec{\nabla}$ & 煦 & 0 & 0 & 12 & 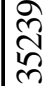 \\
\hline & : & 욱 & m & 离 & & : & $\begin{array}{l}\text { on } \\
\text { ond } \\
\text { to }\end{array}$ & 0 & 0 & 鬲 & & : & $\stackrel{\circ}{\infty}$ & స్ট & 0 & 0 & 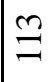 & 黛 \\
\hline & 気 & 0 & \& & $f$ & & ڤ̆ & 总祎 & o & 0 & 员 & & & 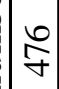 & శ్ & 0 & 0 & a & $\begin{array}{l}\text { क } \\
\text { की } \\
\infty\end{array}$ \\
\hline 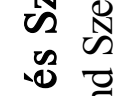 & 官 & 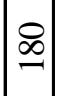 & 员 & ஜे & & 各 & ৪ & م & 0 & 足 & & & 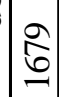 & 옻 & 0 & 0 & 0 & 適 \\
\hline 苞 & 형 & 아 & 0 & \& & & $\frac{t}{0}$ & 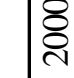 & ?̦ & -1 & 灾 & & $\frac{\pi}{0}$ & 总 & స્ळે & $\sim$ & -1 & - & $\overrightarrow{8}$ \\
\hline$=$ & 苟 & 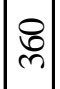 & 0 & ర్ల & $\stackrel{0}{\frac{\pi}{\pi}} \pi$ & ڤั) & 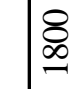 & 常 & 0 & $\begin{array}{l}8 \\
\bar{m}\end{array}$ & 呬 & जे & 守 & 0 & 0 & 0 & 0 & 守 \\
\hline 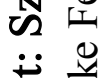 & 哭 & $\mid \begin{array}{c}0 \\
-1\end{array}$ & o & 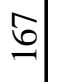 & $\begin{array}{l}ن \\
\ddot{\theta}\end{array}$ & 资 & 8 & 0 & 0 & 8 & $\begin{array}{l}\text { 蒫 } \\
\ddot{7}\end{array}$ & 然 & 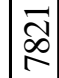 & 0 & 0 & 0 & 0 & 胥 \\
\hline 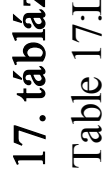 & & 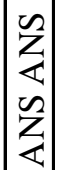 & 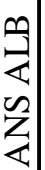 & 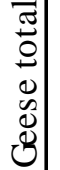 & 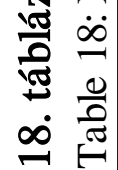 & & $\begin{array}{l}n \\
z \\
4 \\
n \\
z \\
\alpha\end{array}$ & 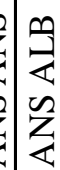 & 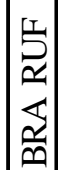 & \begin{tabular}{|l|}
$\pi$ \\
0 \\
0 \\
0 \\
0 \\
0 \\
0 \\
0
\end{tabular} & 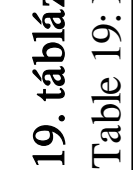 & & 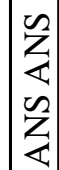 & 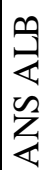 & 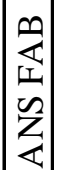 & 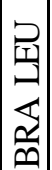 & 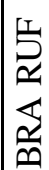 & $\begin{array}{l}7 \pi \\
0 \\
0 \\
0 \\
0 \\
0 \\
0\end{array}$ \\
\hline
\end{tabular}




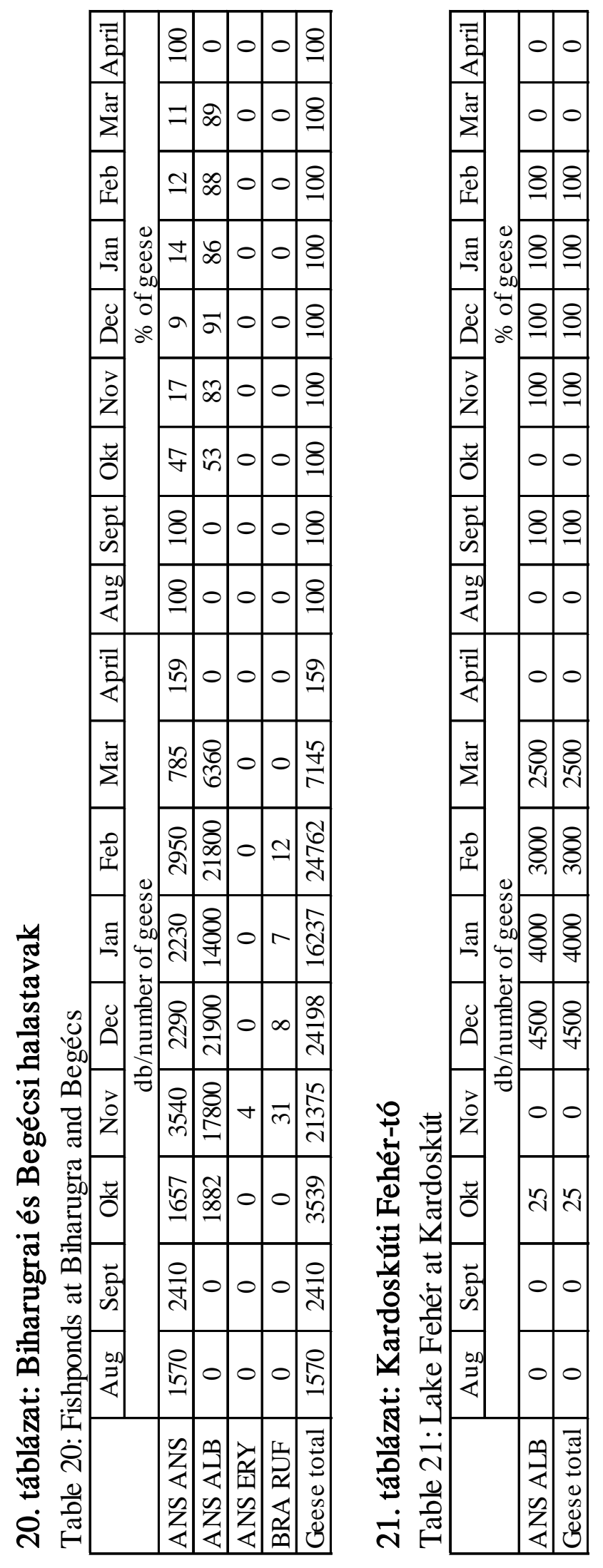


22. táblázat: A vetési lúd dinamikája Magyarországon, 2013/2014.

Table 22: Dynamics of Anser fabalis in Hungary, 2013/2014.

\begin{tabular}{|c|c|c|c|c|c|c|c|c|c|}
\hline Vetési lúd (Anser fabalis) & Aug & Sept & $\mathrm{Oct}$ & Nov & Dec & $\mathrm{Jan}$ & Feb & Mar & April \\
\hline $\begin{array}{l}\text { Fertő-tó } \\
\text { Lake Fertő }\end{array}$ & 0 & 0 & 25 & 438 & 103 & 0 & 138 & 0 & 0 \\
\hline $\begin{array}{l}\text { Kis-Balaton } \\
\text { Kis-Balaton }\end{array}$ & 0 & 0 & 135 & 42 & 50 & 0 & 0 & 0 & 0 \\
\hline $\begin{array}{l}\text { Kelet-Balaton } \\
\text { Lake Balaton-East }\end{array}$ & 0 & 0 & 0 & 55 & 86 & 25 & 110 & 20 & 0 \\
\hline $\begin{array}{l}\text { Tatai Öreg-tó } \\
\text { Old Lake at Tata }\end{array}$ & 0 & 0 & 0 & 2100 & 6000 & 2100 & 540 & 0 & 0 \\
\hline $\begin{array}{l}\text { Velencei-tó és Dinnyési Fertő } \\
\text { Lake Velence and Dinnyési Fertő }\end{array}$ & 0 & 0 & 240 & 26 & 0 & 7 & 3 & 0 & 0 \\
\hline $\begin{array}{l}\text { Soponyai-halastavak } \\
\text { Fishponds at Soponya } \\
\end{array}$ & 0 & 0 & 0 & 15 & 0 & 0 & 0 & 0 & 0 \\
\hline $\begin{array}{l}\text { Rétszilasi-halastavak } \\
\text { Fishponds at Rétszilas }\end{array}$ & 0 & 0 & 0 & 0 & 0 & 0 & 0 & 0 & 0 \\
\hline $\begin{array}{l}\text { Dráva Barcs-Szentborbás } \\
\text { River Dráva: Barcs-Szentborbás }\end{array}$ & 0 & 0 & 0 & 0 & 0 & 0 & 0 & 0 & 0 \\
\hline $\begin{array}{l}\text { Pellérdi-halastavak } \\
\text { Fishponds at Pellérd }\end{array}$ & 0 & 0 & 0 & 0 & 0 & 0 & 0 & 0 & 0 \\
\hline $\begin{array}{l}\text { Sumonyi-halastavak } \\
\text { Fishponds at Sumony } \\
\end{array}$ & 0 & 0 & 1 & 5 & 20 & 200 & 200 & 70 & 0 \\
\hline $\begin{array}{l}\text { Duna Gönyü-Szob } \\
\text { River Danube: Gönyü - Szob }\end{array}$ & 0 & 0 & 0 & 0 & 20 & 6 & 2 & 0 & 0 \\
\hline $\begin{array}{l}\text { Duna Gemenc } \\
\text { River Danube at Gemenc }\end{array}$ & 0 & 50 & 0 & 0 & 0 & 500 & 500 & 50 & 0 \\
\hline $\begin{array}{l}\text { Duna Karapancsa } \\
\text { River Danube at Karapancsa } \\
\end{array}$ & 0 & 0 & 50 & 130 & 350 & 350 & 250 & 160 & 0 \\
\hline $\begin{array}{l}\text { Kiskunsági szikes tavak } \\
\text { Natron lakes in Kiskunság } \\
\end{array}$ & 0 & 0 & 0 & 0 & 1 & 0 & 0 & 0 & 13 \\
\hline $\begin{array}{l}\text { Tömörkényi Csaj-tó } \\
\text { Lake Csaj at Tömörkény }\end{array}$ & 0 & 0 & 0 & 0 & 0 & 0 & 0 & 0 & 0 \\
\hline $\begin{array}{l}\text { Szegedi Fehér-tó és Fertő } \\
\text { Lake Fehér and Fertő at Szeged }\end{array}$ & 0 & 0 & 0 & 0 & 0 & 0 & 0 & 0 & 0 \\
\hline $\begin{array}{l}\text { Tisza-tó } \\
\text { Lake Tisza }\end{array}$ & 0 & 0 & 0 & 0 & 0 & 0 & 0 & 0 & 0 \\
\hline $\begin{array}{l}\text { Hortobágy } \\
\text { Hortobágy }\end{array}$ & 0 & 0 & 2 & 0 & 0 & 0 & 0 & 0 & 0 \\
\hline $\begin{array}{l}\text { Biharugrai és Begécsi halastavak } \\
\text { Fishponds at Biharugra and Begécs }\end{array}$ & 0 & 0 & 0 & 0 & 0 & 0 & 0 & 0 & 0 \\
\hline $\begin{array}{l}\text { Kardoskúti Fehér-tó } \\
\text { Lake Fehér at Kardoskút }\end{array}$ & 0 & 0 & 0 & 0 & 0 & 0 & 0 & 0 & 0 \\
\hline $\begin{array}{l}\text { Magyar or szág összesen } \\
\text { Hungary total }\end{array}$ & 0 & 50 & 453 & 2811 & 6630 & 3188 & 1743 & 300 & 13 \\
\hline
\end{tabular}




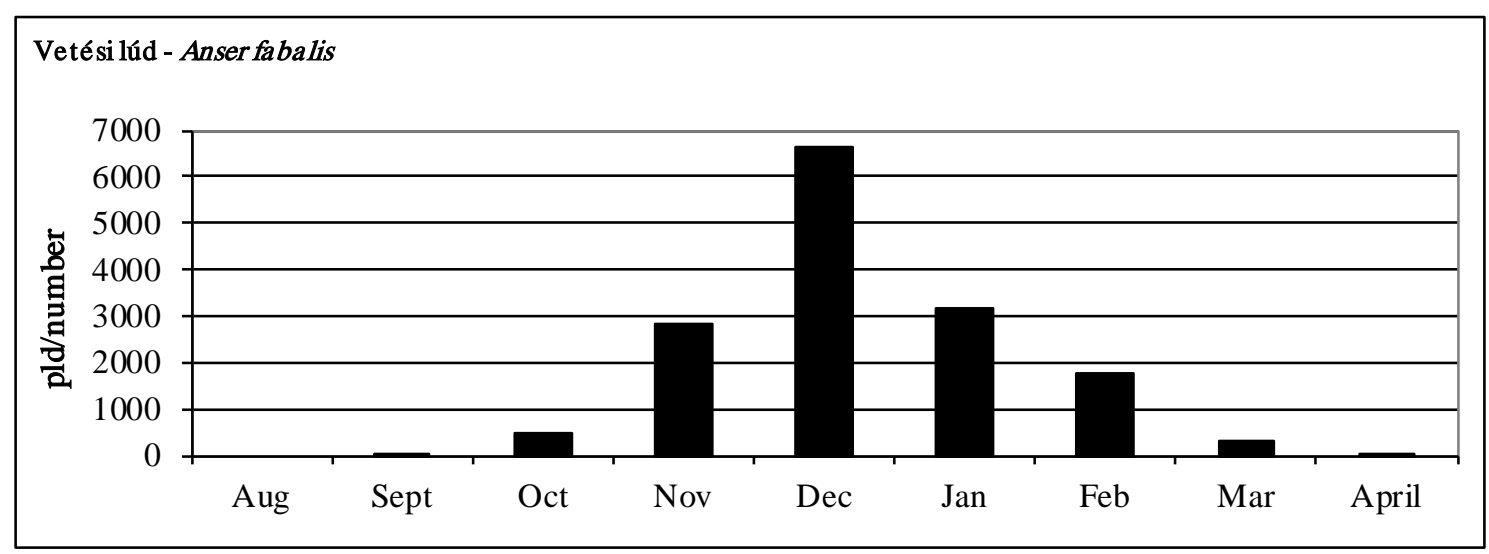

1. ábra: Vetési lúd -Magyarország összesen, 2013/2014.

Figure 1: Anser fabalis - Hungary total, 2013/2014.

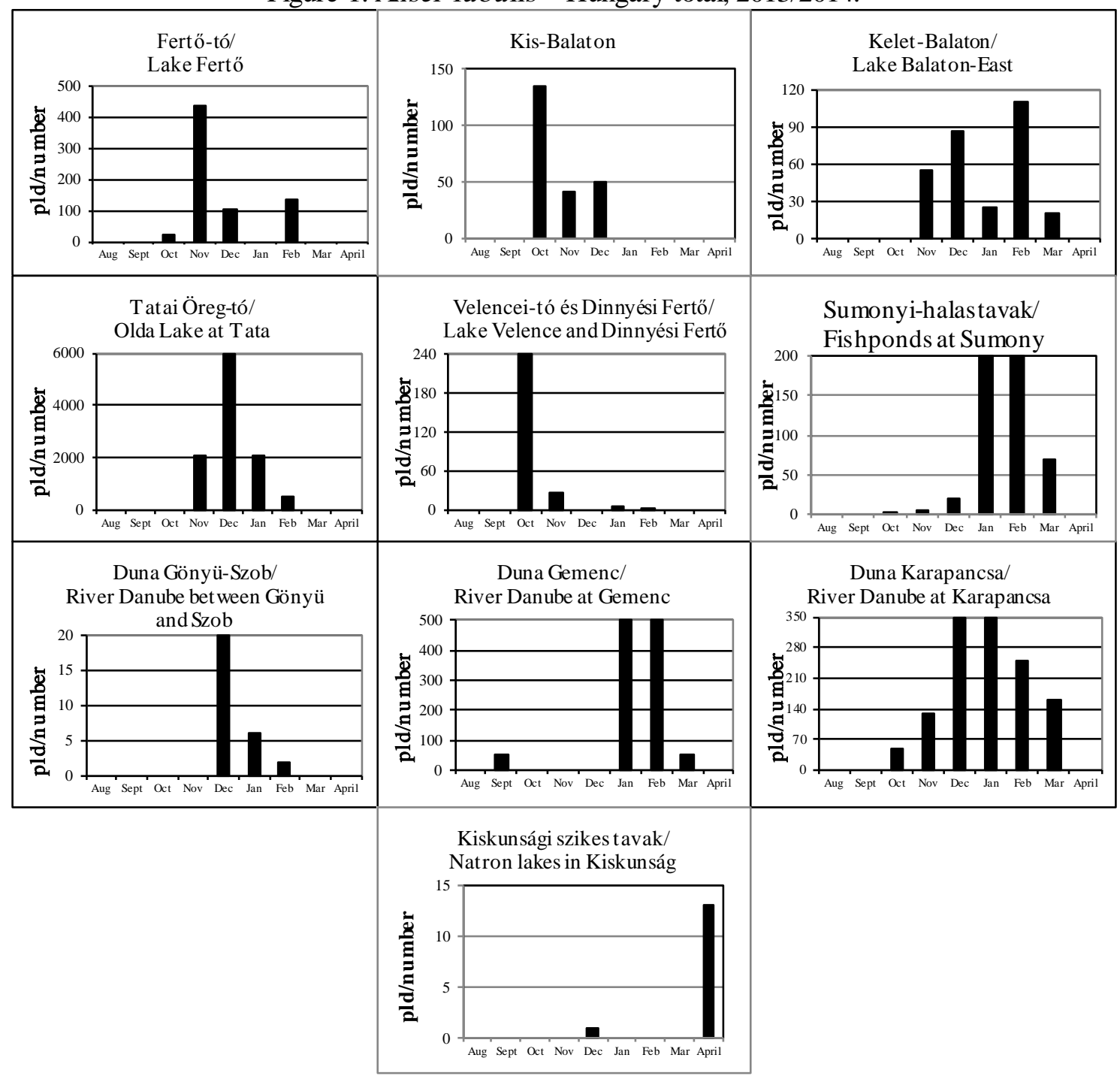

2. ábra: A vetési lúd dinamikája Magyarországon, 2013/2014.

Figure 2: Dynamics of Anser fabalis in Hungary, 2013/2014. 


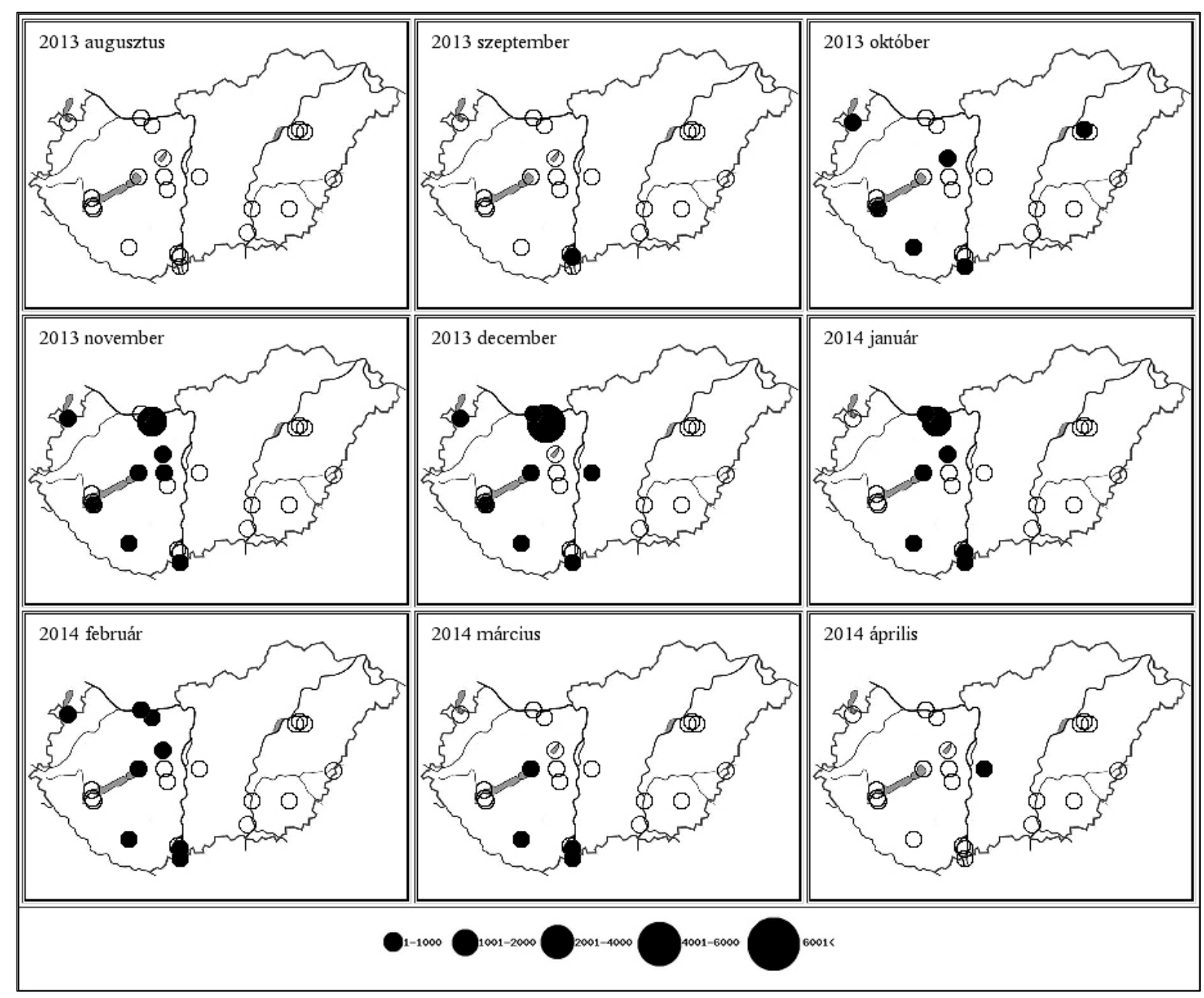

1. térkép: A vetési lúd előfordulás havi mintázata Magyarországon, 2013/2014

Map 1: Monthly distribution pattern of Bean Goose in Hungary, 2013/2014 

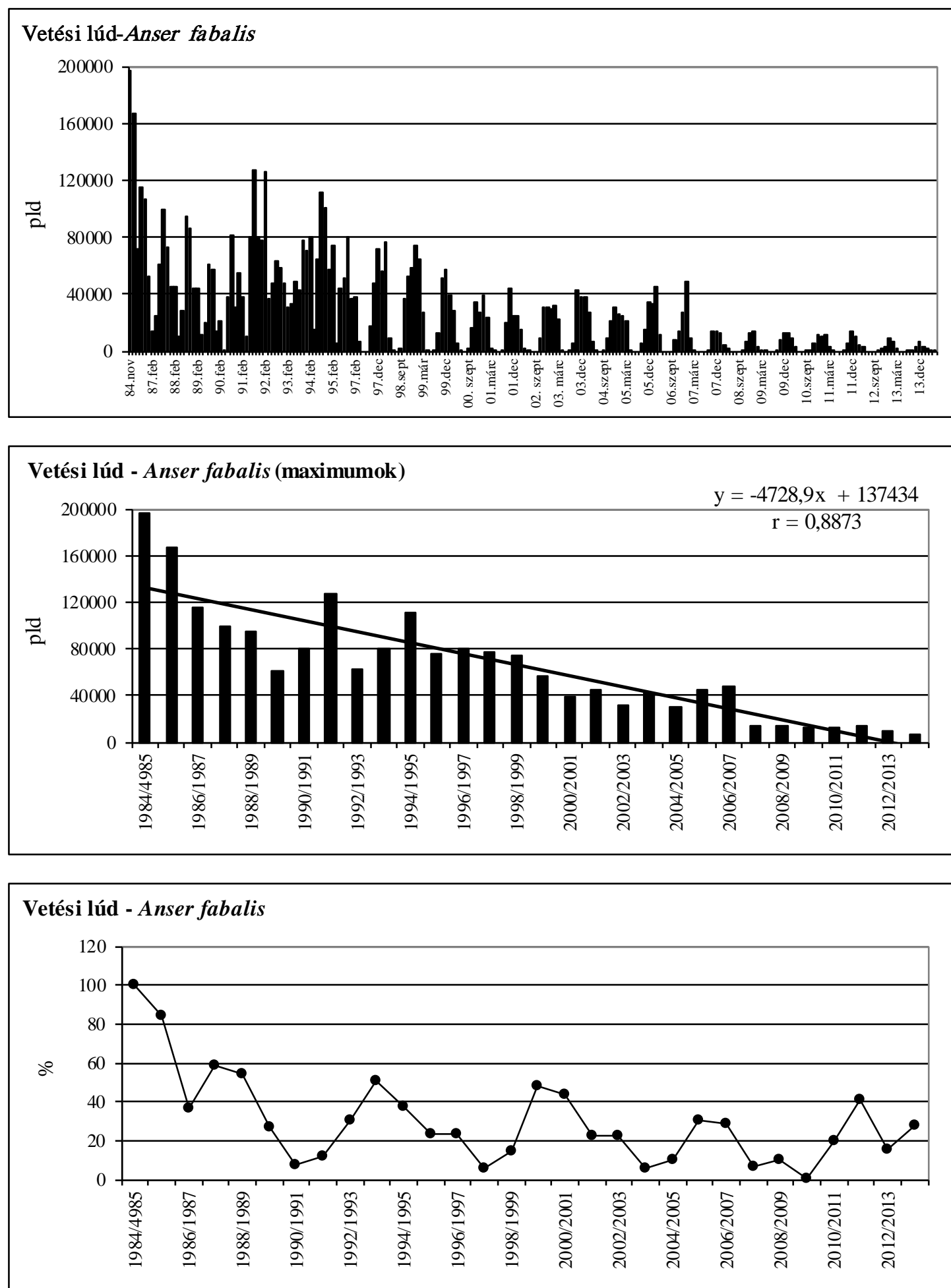

3. ábra: A vetési lúd havi dinamikája, éves maximumának trendje és éves maximumindexe Magyarországon, 1984-2014

Figure 3: Monthly dynamics, trend of maximums and maximum indices for Bean Goose in Hungary, 1984-2014 
23. táblázat: A nagy lilik dinamikája Magyarországon, 2013/2014.

Table 23: Dynamics of Anser albifrons in Hungary, 2013/2014.

\begin{tabular}{|c|c|c|c|c|c|c|c|c|c|}
\hline Nagy lilik (Anser albiffons) & Aug & Sept & Oct & Nov & Dec & Jan & Feb & Mar & April \\
\hline $\begin{array}{l}\text { Fertő-tó } \\
\text { Lake Fertő }\end{array}$ & 0 & 0 & 925 & 7121 & 15334 & 8437 & 11142 & 250 & 0 \\
\hline $\begin{array}{l}\text { Kis-Balaton } \\
\text { Kis-Balaton }\end{array}$ & 0 & 0 & 95 & 3381 & 3000 & 370 & 3 & 0 & 0 \\
\hline $\begin{array}{l}\text { Kelet-Balaton } \\
\text { Lake Balaton-East }\end{array}$ & 0 & 0 & 40 & 180 & 550 & 240 & 290 & 160 & 0 \\
\hline $\begin{array}{l}\text { Tatai Öreg-tó } \\
\text { Old Lake at Tata }\end{array}$ & 0 & 0 & 0 & 19800 & 46500 & 13400 & 1200 & 0 & 0 \\
\hline $\begin{array}{l}\text { Velencei-tó és Dinnyési Fertő } \\
\text { Lake Velence and Dinnyési Fertő }\end{array}$ & 0 & 0 & 3800 & 27800 & 18300 & 38400 & 4400 & 240 & 0 \\
\hline $\begin{array}{l}\text { Soponyai-halastavak } \\
\text { Fishponds at Soponya }\end{array}$ & 0 & 0 & 550 & 6000 & 1000 & 1400 & 50 & 2652 & 0 \\
\hline $\begin{array}{l}\text { Rétszilasi-halastavak } \\
\text { Fishponds at Rétszilas }\end{array}$ & 0 & 0 & 250 & 7450 & 150 & 5000 & 50 & 0 & 0 \\
\hline $\begin{array}{l}\text { Dráva Barcs-Szentborbás } \\
\text { River Dráva: Barcs-Szentborbás }\end{array}$ & 0 & 0 & 0 & 0 & 0 & 0 & 0 & 0 & 0 \\
\hline $\begin{array}{l}\text { Pellérdi-halastavak } \\
\text { Fishponds at Pellérd }\end{array}$ & 0 & 0 & 0 & 0 & 0 & 0 & 0 & 0 & 0 \\
\hline $\begin{array}{l}\text { Sumonyi-halastavak } \\
\text { Fishponds at Sumony }\end{array}$ & 0 & 0 & 0 & 0 & 1200 & 1800 & 140 & 40 & 0 \\
\hline $\begin{array}{l}\text { Duna Gönyü-Szob } \\
\text { River Danube: Gönyü - Szob }\end{array}$ & 0 & 0 & 0 & 0 & 120 & 0 & 0 & 25 & 0 \\
\hline $\begin{array}{l}\text { Duna Gemenc } \\
\text { River Danube at Gemenc }\end{array}$ & 0 & 0 & 0 & 500 & 1500 & 4000 & 4000 & 200 & 0 \\
\hline $\begin{array}{l}\text { Duna Karapancsa } \\
\text { River Danube at Karapancsa }\end{array}$ & 0 & 0 & 20 & 70 & 170 & 500 & 600 & 120 & 0 \\
\hline $\begin{array}{l}\text { Kiskunsági szikes tavak } \\
\text { Natron lakes in Kiskunság }\end{array}$ & 0 & 0 & 10 & 22900 & 264 & 275 & 4698 & 3409 & 862 \\
\hline $\begin{array}{l}\text { Tömörkényi Csaj-tó } \\
\text { Lake Csaj at Tömörkény }\end{array}$ & 0 & 0 & 0 & 2200 & 5000 & 40 & 1700 & 2000 & 0 \\
\hline $\begin{array}{l}\text { Szegedi Fehér-tó és Fertő } \\
\text { Lake Fehér and Fertő at Szeged }\end{array}$ & 0 & 0 & 0 & 250 & 40 & 36 & 275 & 0 & 0 \\
\hline $\begin{array}{l}\text { Tisza-tó } \\
\text { Lake Tisza }\end{array}$ & 0 & 1300 & 1200 & 500 & 0 & 0 & 190 & 300 & 40 \\
\hline $\begin{array}{l}\text { Hortobágy } \\
\text { Hortobágy }\end{array}$ & 0 & 0 & 2230 & 22910 & 8002 & 22660 & 33150 & 13025 & 2014 \\
\hline $\begin{array}{l}\text { Biharugrai és Begécsi halastavak } \\
\text { Fishponds at Biharugra and Begécs }\end{array}$ & 0 & 0 & 1882 & 17800 & 21900 & 14000 & 21800 & 6360 & 0 \\
\hline $\begin{array}{l}\text { Kardoskúti Fehér-tó } \\
\text { Lake Fehér at Kardoskút }\end{array}$ & 0 & 0 & 25 & 0 & 4500 & 4000 & 3000 & 2500 & 0 \\
\hline $\begin{array}{l}\text { Magyar or szág összesen } \\
\text { Hungary total }\end{array}$ & 0 & 1300 & 11027 & 138862 & 127530 & 114558 & 86688 & 31281 & 2916 \\
\hline
\end{tabular}




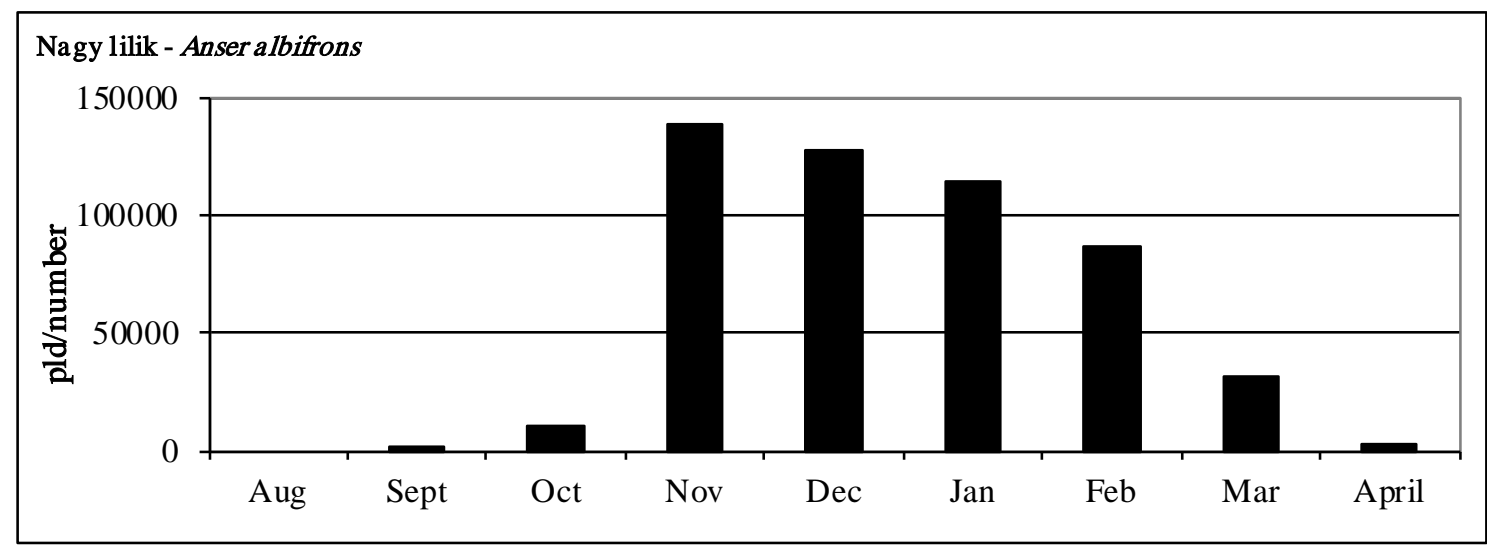

4. ábra: Nagy lilik -Magyarország összesen, 2013/2014.

Figure 4: Anser albifrons - Hungary total, 2013/2014.

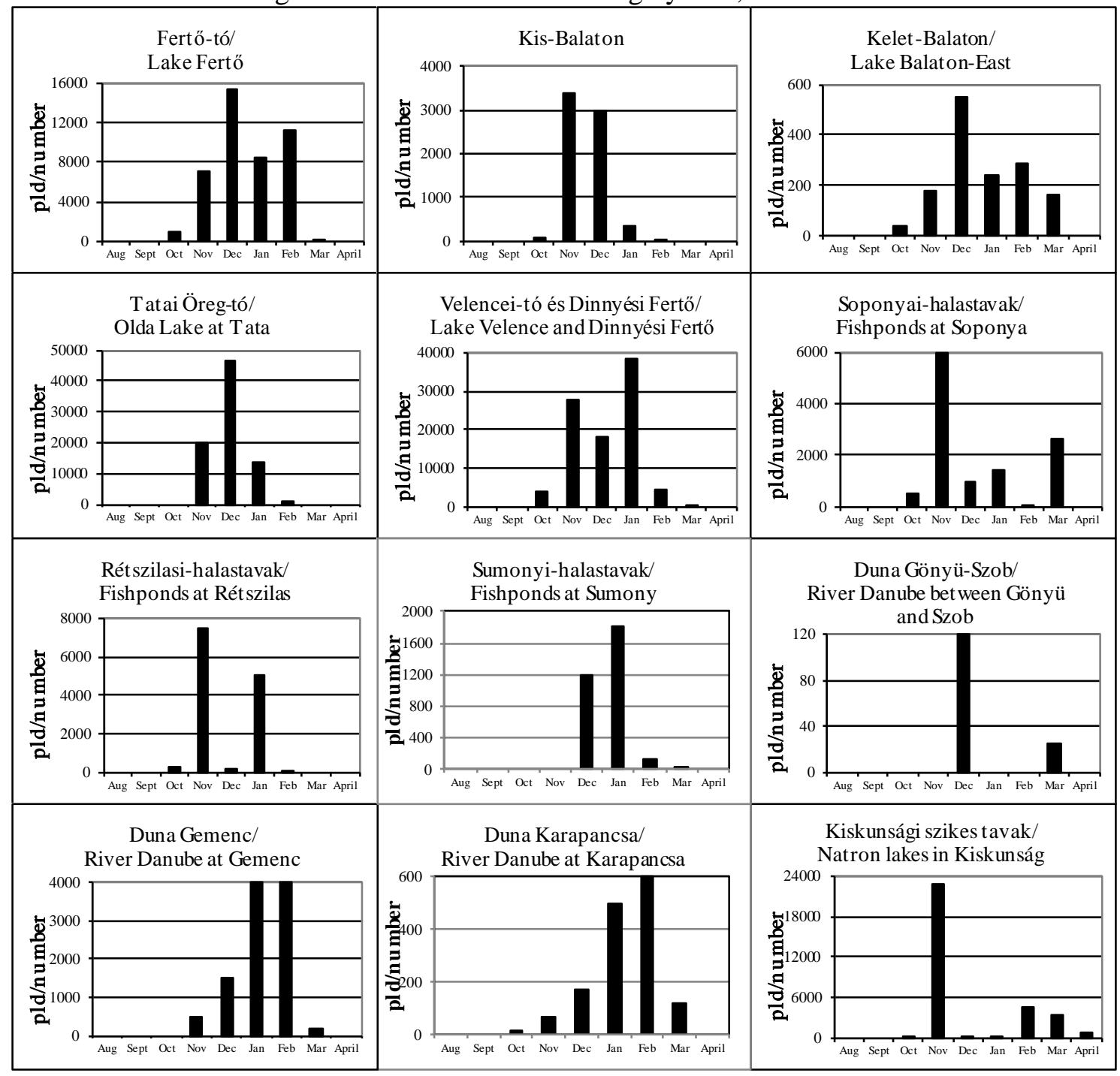

5. ábra: A nagy lilik dinamikája Magyarországon, 2013/2014.

Figure 5: Dynamics of Anser albifronss in Hungary, 2013/2014. 


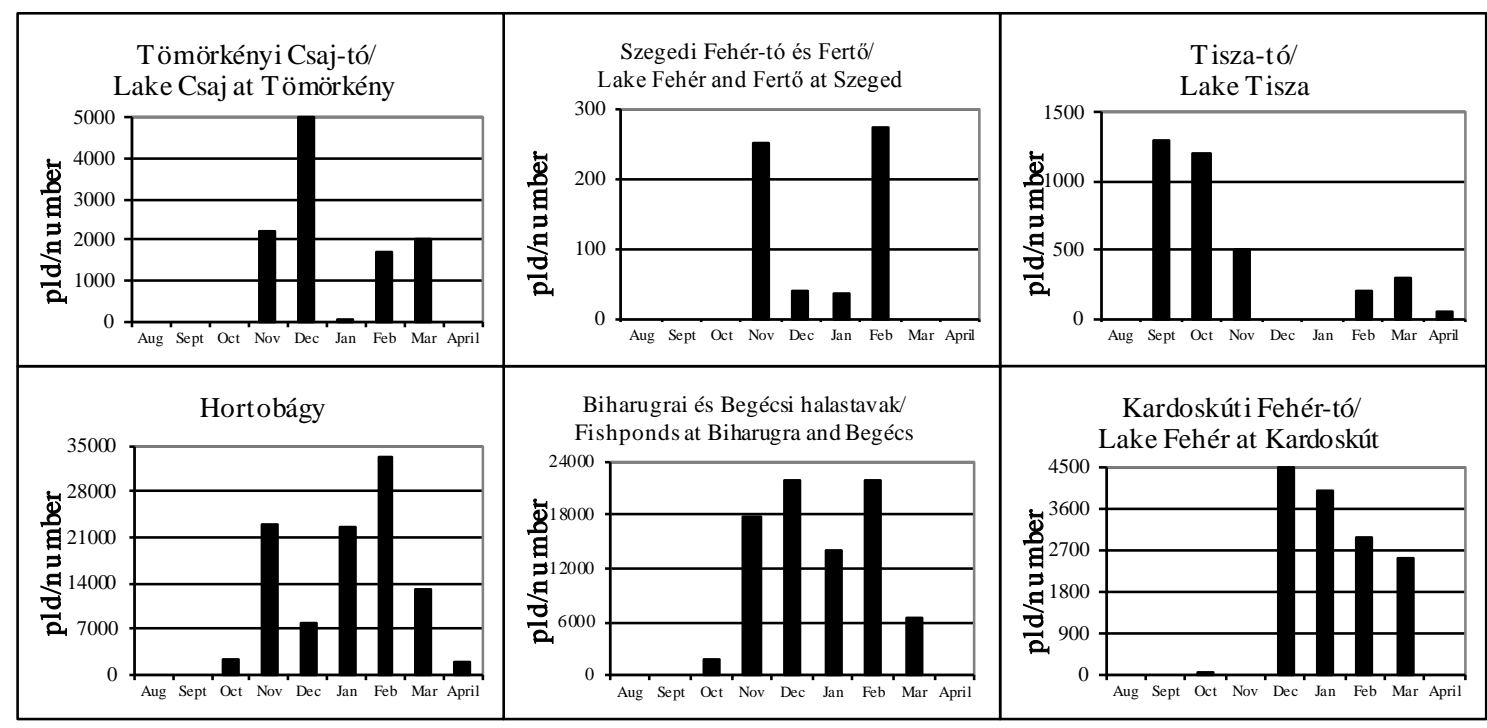

5. ábra: A nagy lilik dinamikája Magyarországon, 2013/2014.

Figure 5: Dynamics of Anser albifronss in Hungary, 2013/2014.

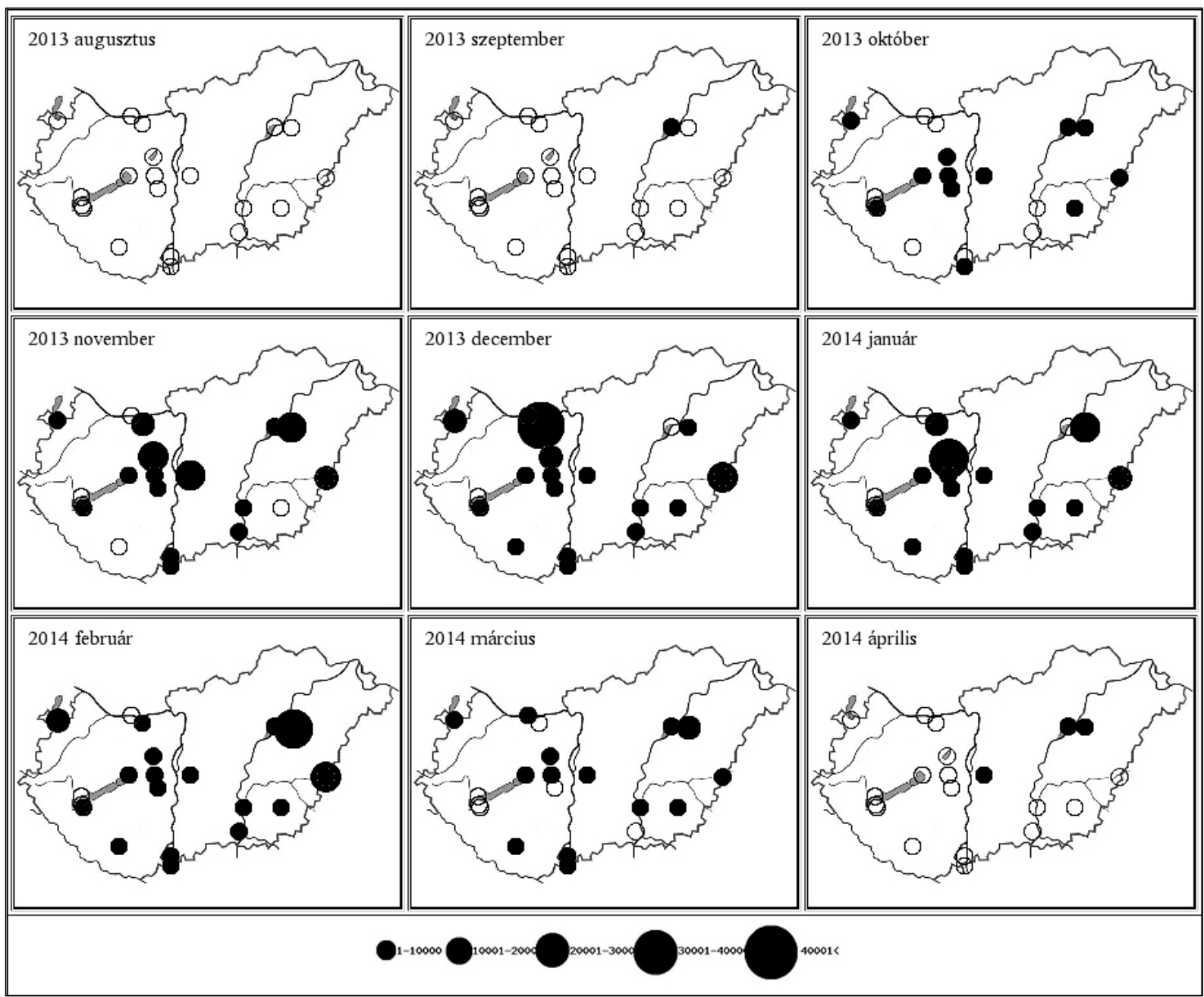

2. térkép: A nagy lilik előfordulás havi mintázata Magyarországon, 2013/2014

Map 2: Monthly distribution pattern of White-fronted Goose in Hungary, 2013/2014 

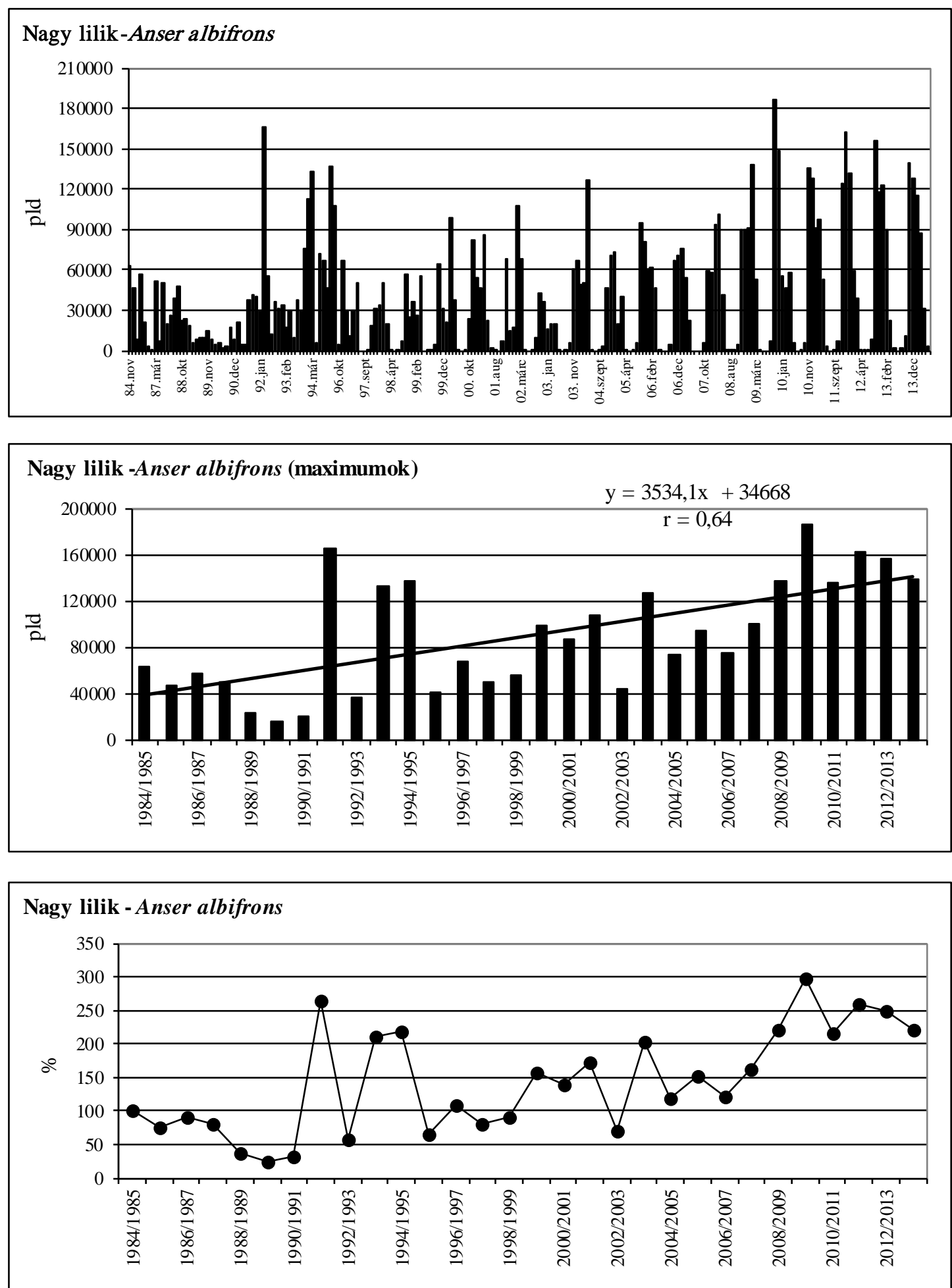

6. ábra: A nagy lilik havi dinamikája, éves maximumának trendje és éves maximumindexe Magyarországon, 1984-2014

Figure 6: Monthly dynamics, trend of yearly maximums and maximum indices for White-fronted Goose in Hungary, 1984-2014 
24. táblázat: A kis lilik dinamikája Magyarországon, 2013/2014.

Table 24: Dynamics of Anser erythropus in Hungary, 2013/2014.

\begin{tabular}{|c|c|c|c|c|c|c|c|c|c|}
\hline Kis lilik (Anser erythropus) & Aug & Sept & Oct & Nov & Dec & Jan & Feb & Mar & April \\
\hline $\begin{array}{l}\text { Fertő-tó } \\
\text { Lake Fertő }\end{array}$ & 0 & 0 & 0 & 0 & 0 & 20 & 60 & 0 & 0 \\
\hline $\begin{array}{l}\text { Kis-Balaton } \\
\text { Kis-Balaton }\end{array}$ & 0 & 0 & 0 & 0 & 0 & 0 & 0 & 0 & 0 \\
\hline $\begin{array}{l}\text { Kelet-Balaton } \\
\text { Lake Balaton-East }\end{array}$ & 0 & 0 & 0 & 0 & 0 & 0 & 0 & 0 & 0 \\
\hline $\begin{array}{l}\text { Tatai Öreg-tó } \\
\text { Old Lake at Tata }\end{array}$ & 0 & 0 & 0 & 4 & 2 & 0 & 0 & 0 & 0 \\
\hline $\begin{array}{l}\text { Velencei-tó és Dinnyési Fertő } \\
\text { Lake Velence and Dinnyési Fertő }\end{array}$ & 0 & 0 & 0 & 0 & 0 & 0 & 0 & 0 & 0 \\
\hline $\begin{array}{l}\text { Soponyai-halastavak } \\
\text { Fishponds at Soponya }\end{array}$ & 0 & 0 & 0 & 0 & 2 & 0 & 0 & 0 & 0 \\
\hline $\begin{array}{l}\text { Rétszilasi-halastavak } \\
\text { Fishponds at Rétszilas }\end{array}$ & 0 & 0 & 0 & 0 & 0 & 0 & 0 & 0 & 0 \\
\hline $\begin{array}{l}\text { Dráva Barcs-Szentborbás } \\
\text { River Dráva: Barcs-Szentborbás }\end{array}$ & 0 & 0 & 0 & 0 & 0 & 0 & 0 & 0 & 0 \\
\hline $\begin{array}{l}\text { Pellérdi-halastavak } \\
\text { Fishponds at Pellérd } \\
\end{array}$ & 0 & 0 & 0 & 0 & 0 & 0 & 0 & 0 & 0 \\
\hline $\begin{array}{l}\text { Sumonyi-halastavak } \\
\text { Fishponds at Sumony } \\
\end{array}$ & 0 & 0 & 0 & 0 & 0 & 0 & 0 & 0 & 0 \\
\hline $\begin{array}{l}\text { Duna Gönyü-Szob } \\
\text { River Danube: Gönyü - Szob }\end{array}$ & 0 & 0 & 0 & 0 & 0 & 0 & 0 & 0 & 0 \\
\hline $\begin{array}{l}\text { Duna Gemenc } \\
\text { River Danube at Gemenc }\end{array}$ & 0 & 0 & 0 & 0 & 0 & 1 & 1 & 0 & 0 \\
\hline $\begin{array}{l}\text { Duna Karapancsa } \\
\text { River Danube at Karapancsa }\end{array}$ & 0 & 0 & 0 & 0 & 1 & 0 & 0 & 0 & 0 \\
\hline $\begin{array}{l}\text { Kiskunsági szikes tavak } \\
\text { Natron lakes in Kiskunság }\end{array}$ & 0 & 0 & 0 & 0 & 0 & 0 & 0 & 0 & 0 \\
\hline $\begin{array}{l}\text { Tömörkényi Csaj-tó } \\
\text { Lake Csaj at Tömörkény }\end{array}$ & 0 & 0 & 0 & 0 & 0 & 0 & 0 & 1 & 0 \\
\hline $\begin{array}{l}\text { Szegedi Fehér-tó és Fertő } \\
\text { Lake Fehér and Fertő at Szeged }\end{array}$ & 0 & 0 & 0 & 0 & 0 & 0 & 0 & 0 & 0 \\
\hline $\begin{array}{l}\text { Tisza-tó } \\
\text { Lake Tisza }\end{array}$ & 0 & 0 & 0 & 0 & 0 & 0 & 0 & 0 & 0 \\
\hline $\begin{array}{l}\text { Hortobágy } \\
\text { Hortobágy }\end{array}$ & 0 & 0 & 0 & 0 & 0 & 0 & 0 & 0 & 0 \\
\hline $\begin{array}{l}\text { Biharugrai és Begécsi halastavak } \\
\text { Fishponds at Biharugra and Begécs }\end{array}$ & 0 & 0 & 0 & 4 & 0 & 0 & 0 & 0 & 0 \\
\hline $\begin{array}{l}\text { Kardoskúti Fehér-tó } \\
\text { Lake Fehér at Kardoskút }\end{array}$ & 0 & 0 & 0 & 0 & 0 & 0 & 0 & 0 & 0 \\
\hline $\begin{array}{l}\text { Magyar or szág összesen } \\
\text { Hungary total }\end{array}$ & 0 & 0 & 0 & 8 & 5 & 21 & 61 & 1 & 0 \\
\hline
\end{tabular}




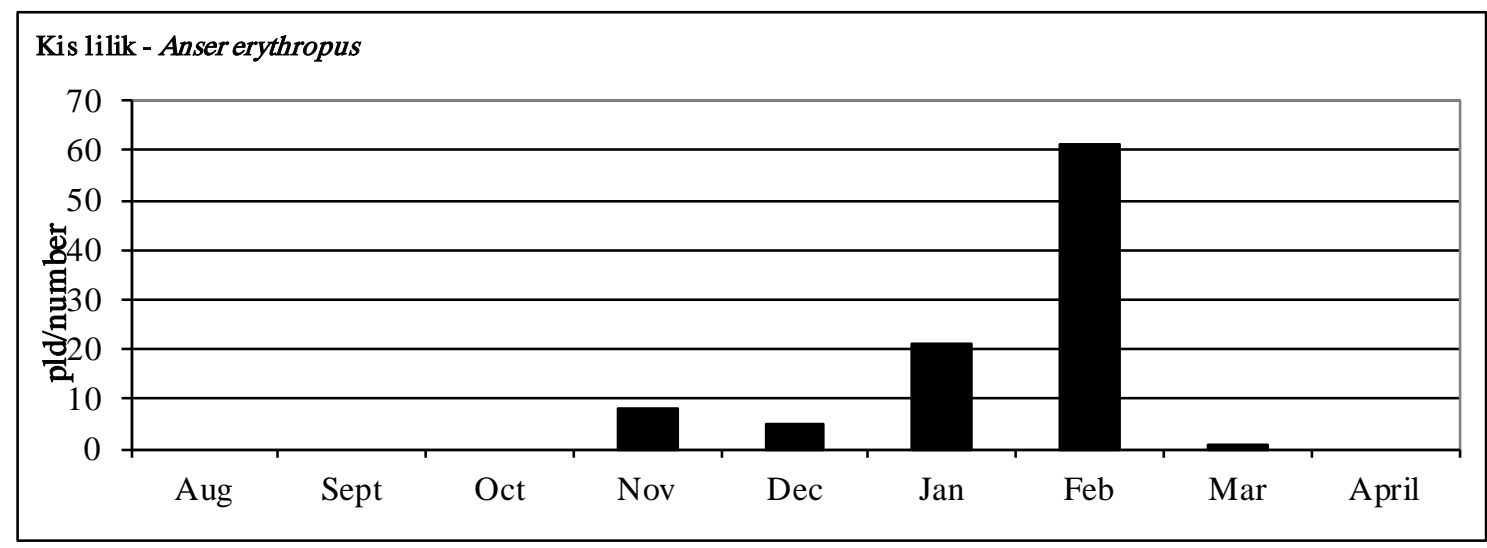

7. ábra: Kis lilik -Magyarország összesen, 2013/2014.

Figure 7: Anser erythropus - Hungary total, 2013/2014.

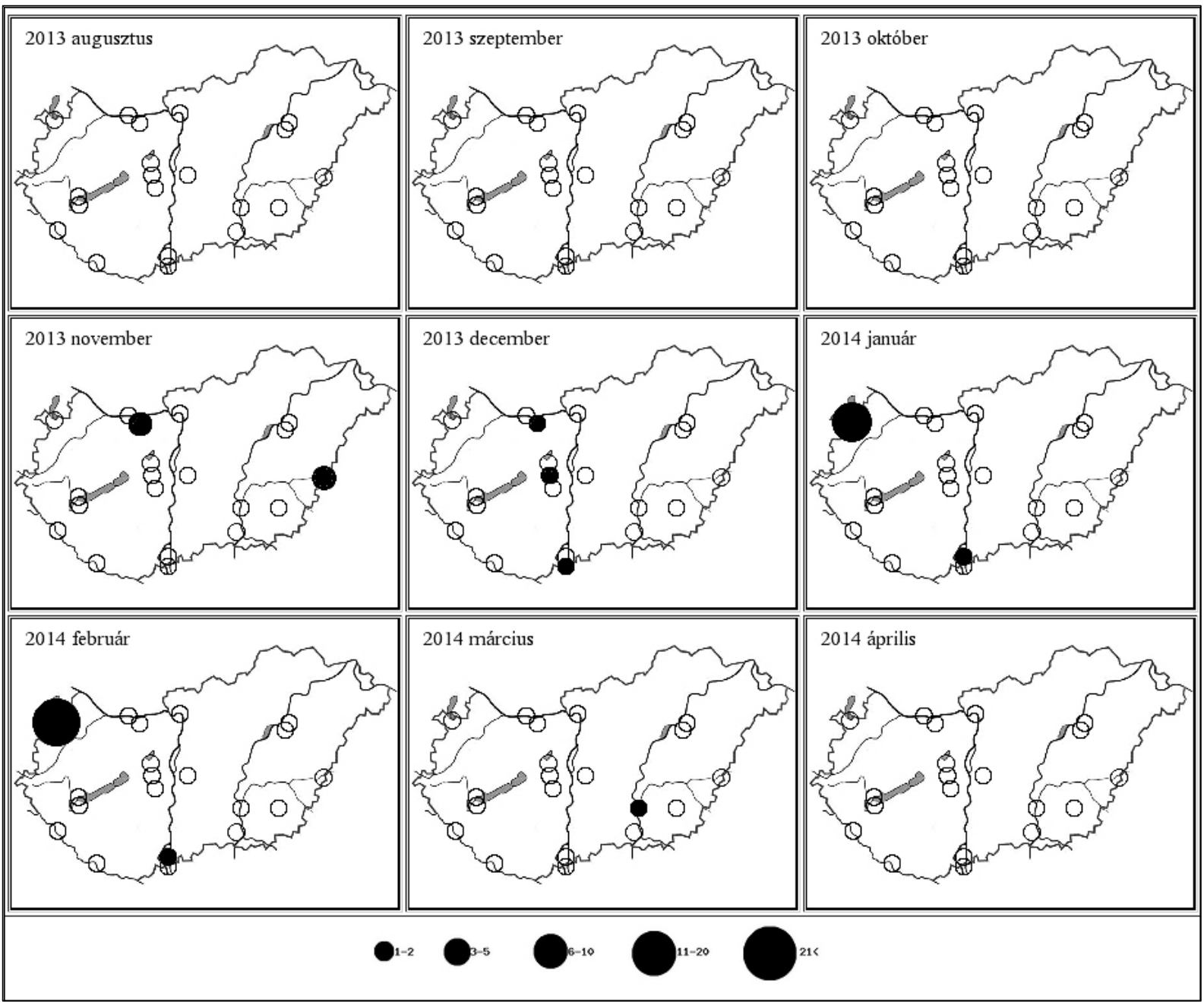

3. térkép: A kis lilik előfordulás havi mintázata Magyarországon, 2013/2014

Map 3: Monthly distribution pattern of Lesser White-fronted Goose in Hungary, 2013/2014 


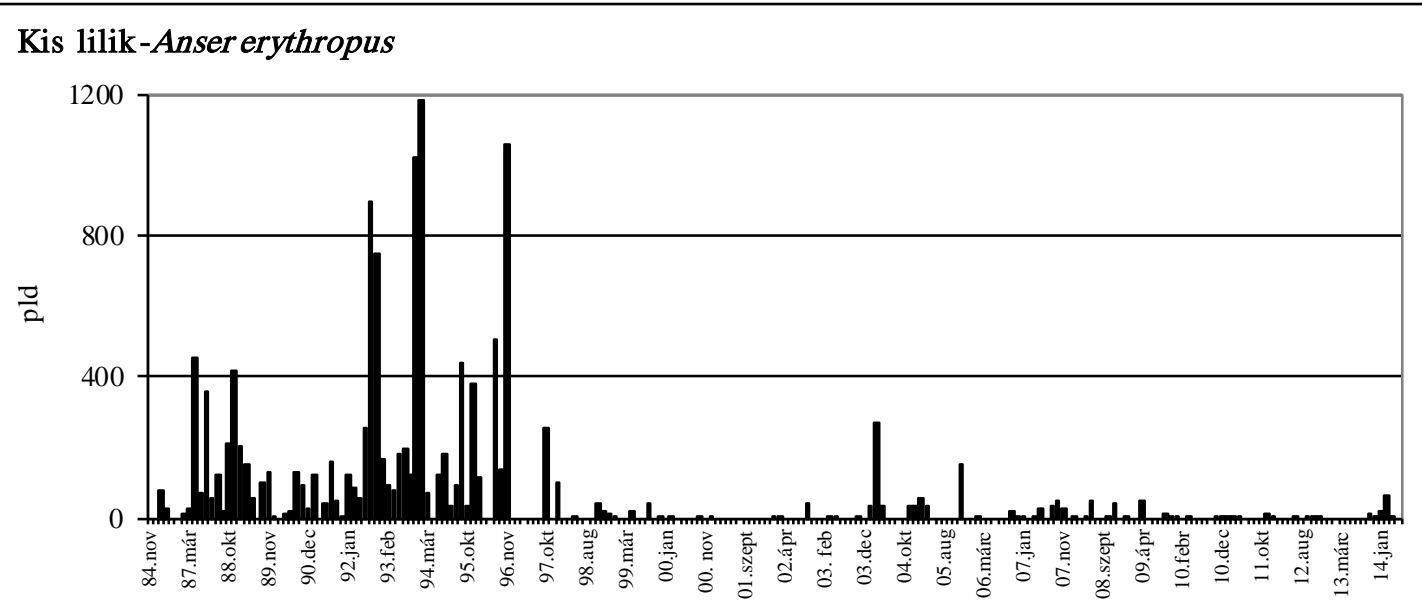

Kis lilik - Anser erythropus (maximumok)

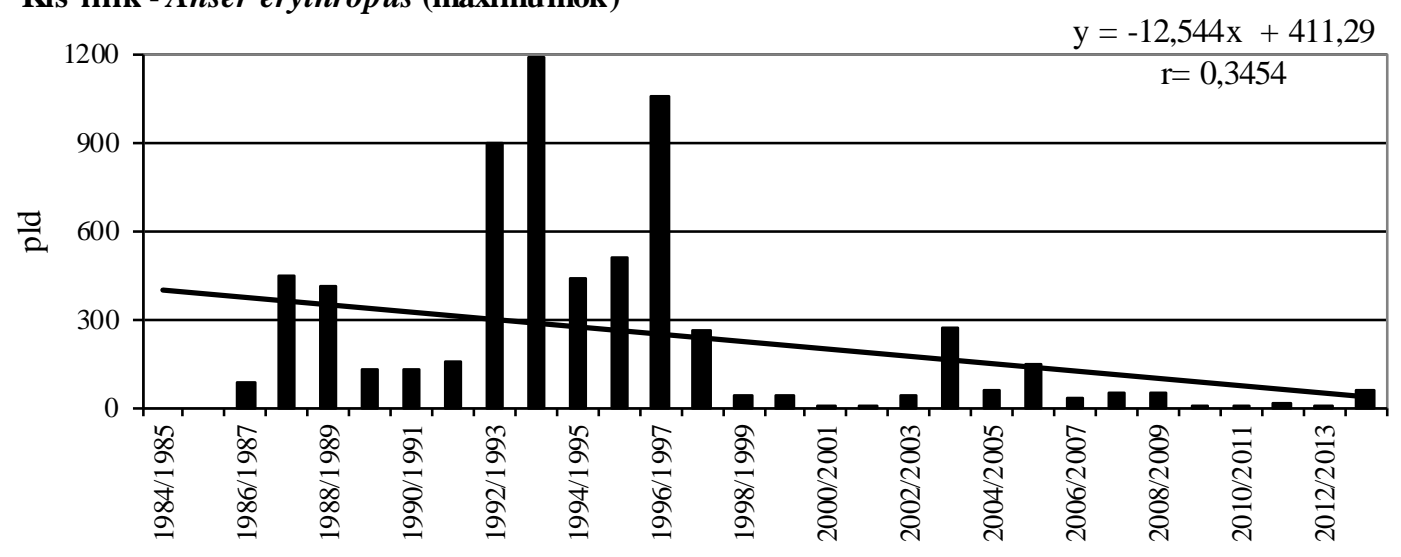

Kis lilik - Anser erythropus

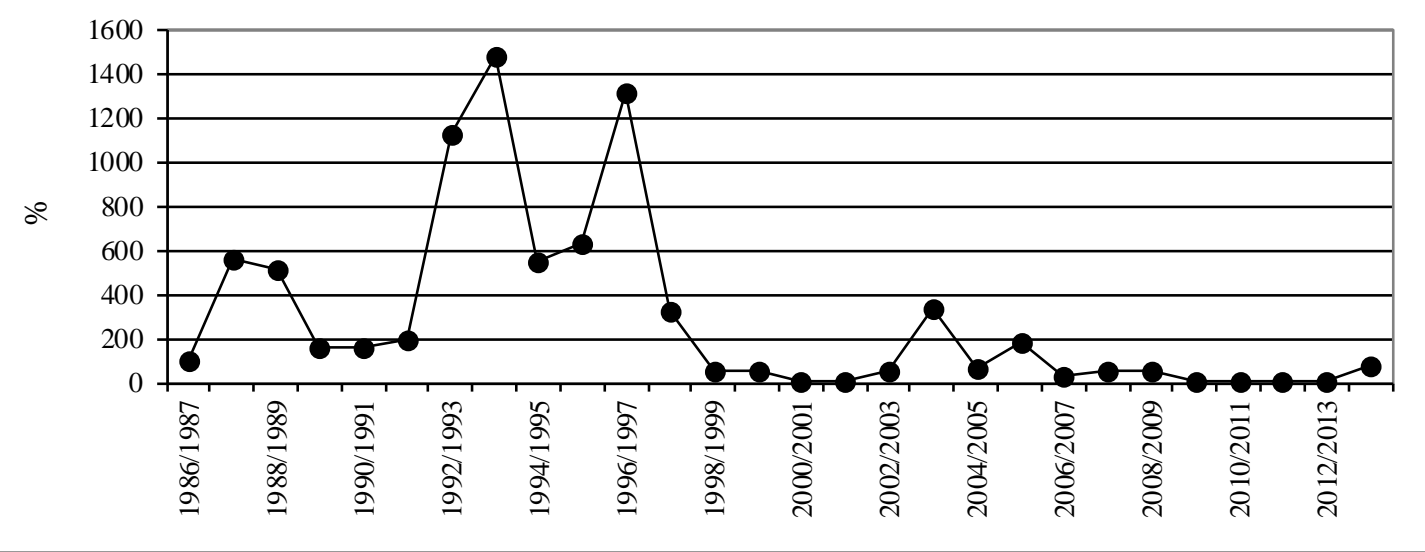

8. ábra: A kis lilik havi dinamikája, éves maximumának trendje és éves maximumindexe Magyarországon, 1984-2014

Figure 8: Monthly dynamics, trend of yearly maximum and maximum indices for Lesser Whitefronted Goose in Hungary, 1984-2014 
25. táblázat: A nyári lúd dinamikája Magyarországon, 2013/2014.

Table 25: Dynamics of Anser anser in Hungary, 2013/2014.

\begin{tabular}{|c|c|c|c|c|c|c|c|c|c|}
\hline Nyári lúd (Anser anser) & Aug & Sept & Oct & Nov & Dec & Jan & $\mathrm{Feb}$ & Mar & April \\
\hline $\begin{array}{l}\text { Fertő-tó } \\
\text { Lake Fertő }\end{array}$ & 200 & 1700 & 1901 & 2124 & 6318 & 1495 & 3541 & 1042 & 903 \\
\hline $\begin{array}{l}\text { Kis-Balaton } \\
\text { Kis-Balaton }\end{array}$ & 1623 & 2413 & 6429 & 4868 & 3145 & 2050 & 373 & 73 & 323 \\
\hline $\begin{array}{l}\text { Kelet-Balaton } \\
\text { Lake Balaton-East }\end{array}$ & 86 & 97 & 180 & 270 & 100 & 40 & 70 & 80 & 72 \\
\hline $\begin{array}{l}\text { Tatai Öreg-tó } \\
\text { Old Lake at Tata }\end{array}$ & 0 & 0 & 0 & 70 & 500 & 40 & 0 & 0 & 2 \\
\hline $\begin{array}{l}\text { Velencei-tó és Dinnyési Fertő } \\
\text { Lake Velence and Dinnyési Fertő }\end{array}$ & 920 & 1700 & 1280 & 1770 & 1130 & 530 & 300 & 90 & 85 \\
\hline $\begin{array}{l}\text { Soponyai-halastavak } \\
\text { Fishponds at Soponya }\end{array}$ & 1200 & 1120 & 3850 & 2063 & 400 & 809 & 68 & 217 & 149 \\
\hline $\begin{array}{l}\text { Rétszilasi-halastavak } \\
\text { Fishponds at Rétszilas } \\
\end{array}$ & 1240 & 2400 & 2050 & 4270 & 900 & 1717 & 522 & 316 & 345 \\
\hline $\begin{array}{l}\text { Dráva Barcs-Szentborbás } \\
\text { River Dráva: Barcs-Szentborbás }\end{array}$ & 0 & 0 & 0 & 0 & 0 & 0 & 0 & 0 & 0 \\
\hline $\begin{array}{l}\text { Pellérdi-halastavak } \\
\text { Fishponds at Pellérd }\end{array}$ & 0 & 0 & 0 & 0 & 0 & 0 & 0 & 0 & 0 \\
\hline $\begin{array}{l}\text { Sumonyi-halastavak } \\
\text { Fishponds at Sumony } \\
\end{array}$ & 0 & 0 & 0 & 27 & 400 & 150 & 90 & 30 & 4 \\
\hline $\begin{array}{l}\text { Duna Gönyü-Szob } \\
\text { River Danube: Gönyü - Szob }\end{array}$ & 0 & 0 & 0 & 0 & 0 & 0 & 0 & 0 & 0 \\
\hline $\begin{array}{l}\text { Duna Gemenc } \\
\text { River Danube at Gemenc } \\
\end{array}$ & 200 & 0 & 300 & 300 & 500 & 700 & 700 & 100 & 0 \\
\hline $\begin{array}{l}\text { Duna Karapancsa } \\
\text { River Danube at Karapancsa } \\
\end{array}$ & 300 & 350 & 450 & 450 & 650 & 300 & 200 & 400 & 150 \\
\hline $\begin{array}{l}\text { Kiskunsági szikes tavak } \\
\text { Natron lakes in Kiskunság } \\
\end{array}$ & 454 & 30 & 456 & 329 & 121 & 483 & 305 & 206 & 0 \\
\hline $\begin{array}{l}\text { Tömörkényi Csaj-tó } \\
\text { Lake Csaj at Tömörkény }\end{array}$ & 230 & 260 & 240 & 270 & 400 & 2 & 120 & 80 & 210 \\
\hline $\begin{array}{l}\text { Szegedi Fehér-tó és Fertő } \\
\text { Lake Fehér and Fertő at Szeged }\end{array}$ & 167 & 360 & 400 & 180 & 0 & 150 & 363 & 69 & 185 \\
\hline $\begin{array}{l}\text { Tisza-tó } \\
\text { Lake Tisza }\end{array}$ & 60 & 1800 & 2000 & 900 & 850 & 350 & 900 & 900 & 600 \\
\hline $\begin{array}{l}\text { Hortobágy } \\
\text { Hortobágy }\end{array}$ & 7821 & 9490 & 14380 & 1679 & 476 & 802 & 2014 & 1747 & 1609 \\
\hline $\begin{array}{l}\text { Biharugrai és Begécsi halastavak } \\
\text { Fishponds at Biharugra and Begécs }\end{array}$ & 1570 & 2410 & 1657 & 3540 & 2290 & 2230 & 2950 & 785 & 159 \\
\hline $\begin{array}{l}\text { Kardoskúti Fehér-tó } \\
\text { Lake Fehér at Kardoskút }\end{array}$ & 0 & 0 & 0 & 0 & 0 & 0 & 0 & 0 & 0 \\
\hline $\begin{array}{l}\text { Magyar or szág összesen } \\
\text { Hungary total }\end{array}$ & 16071 & 24130 & 35573 & 23110 & 18180 & 11848 & 12516 & 6135 & 4796 \\
\hline
\end{tabular}




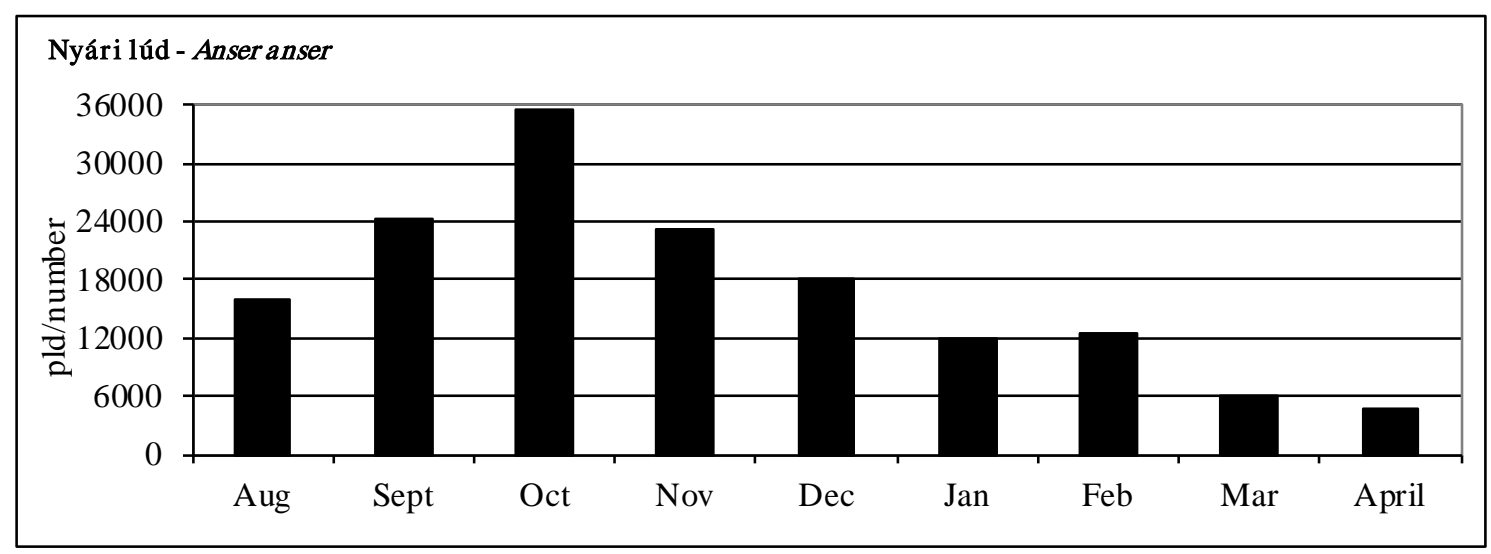

9. ábra: Nyári lúd -Magyarország összesen, 2013/2014.

Figure 9: Anser anser - Hungary total, 2013/2014.

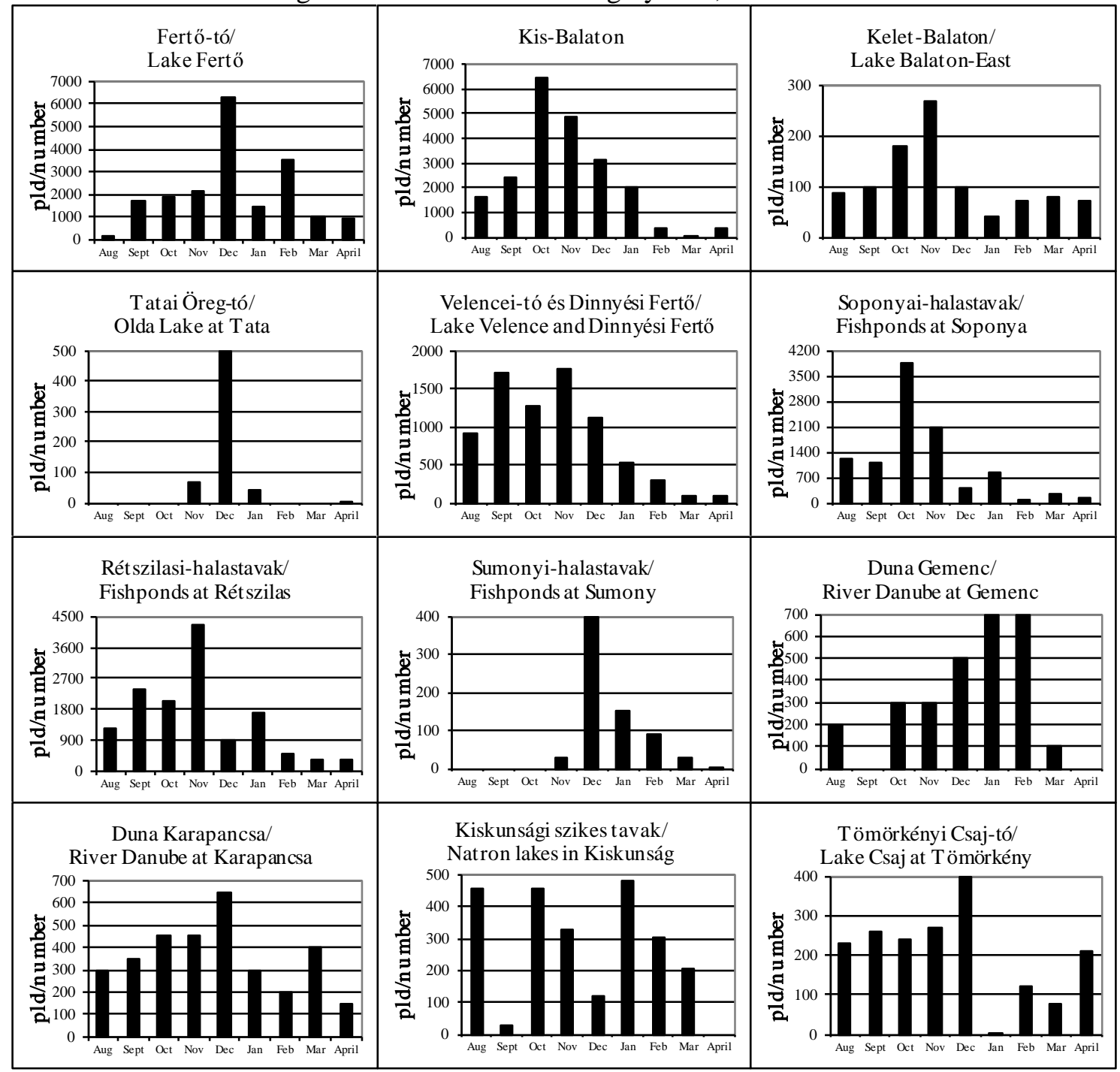

10. ábra: A nyári lúd dinamikája Magyarországon, 2013/2014.

Figure 10: Dynamics of Anser anser in Hungary, 2013/2014. 


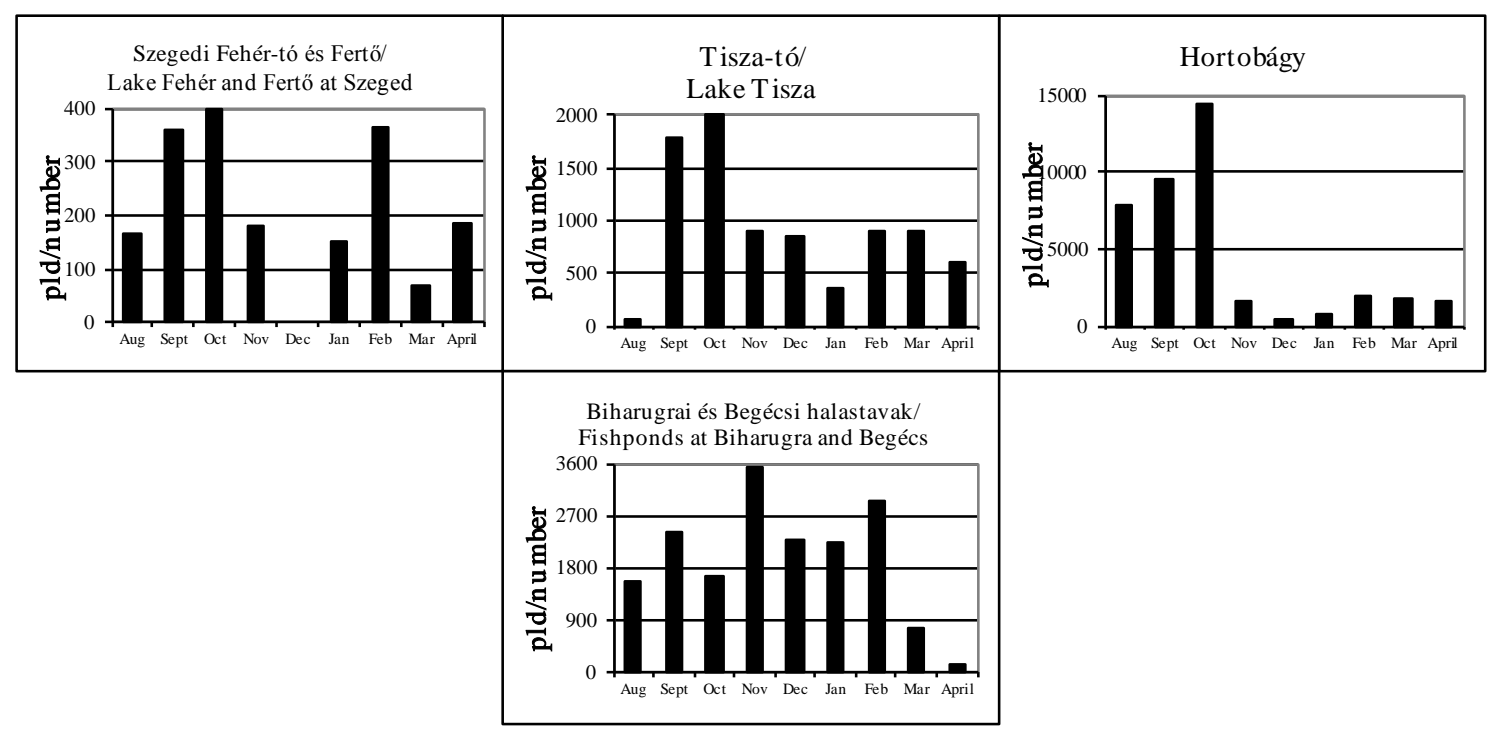

10. ábra: A nyári lúd dinamikája Magyarországon, 2013/2014.

Figure 10: Dynamics of Anser anser in Hungary, 2013/2014.

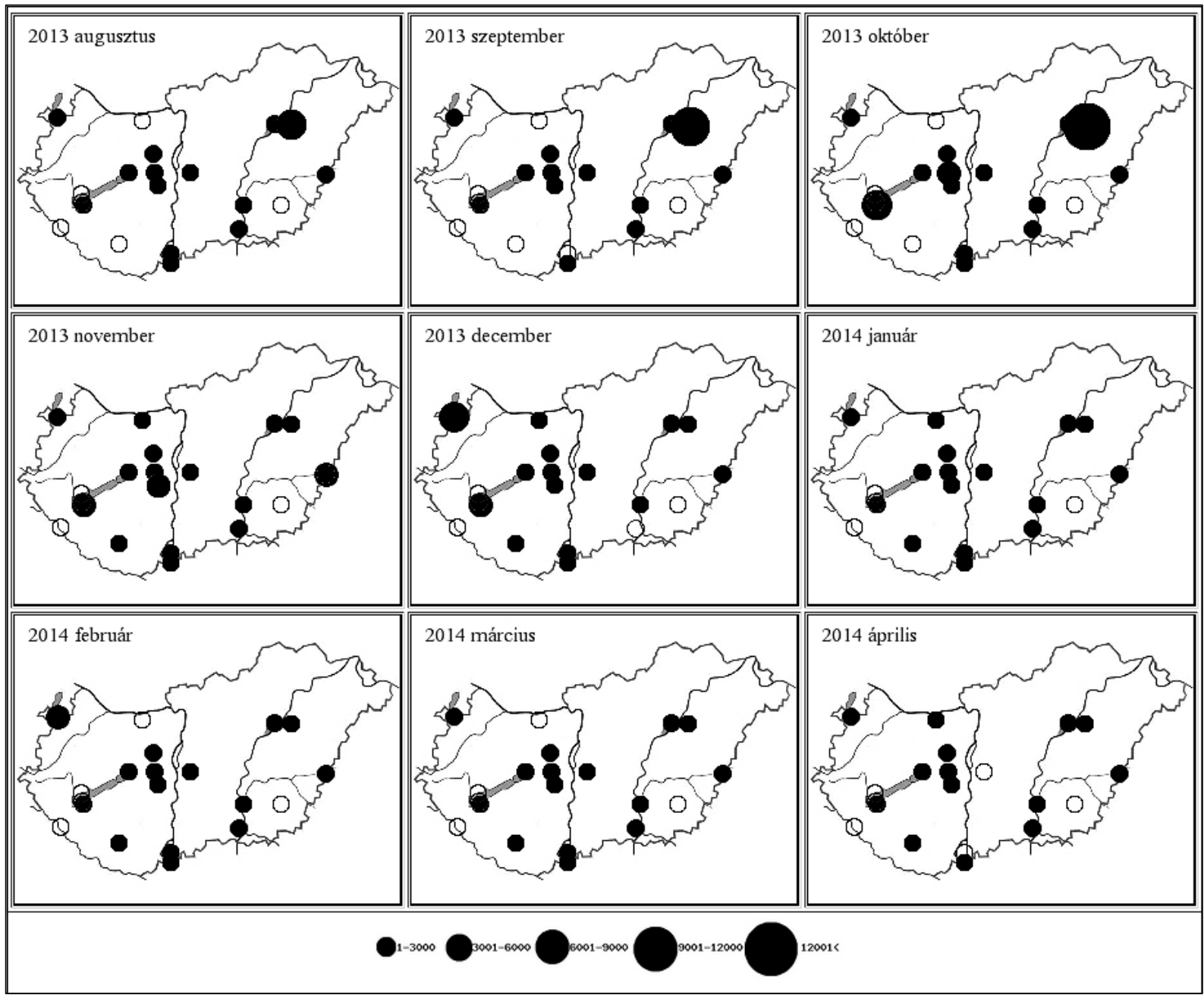

4. térkép: A nyári lúd előfordulás havi mintázata Magyarországon, 2013/2014

Map 4: Monthly distribution pattern of Greylag Goose in Hungary, 2013/2014 

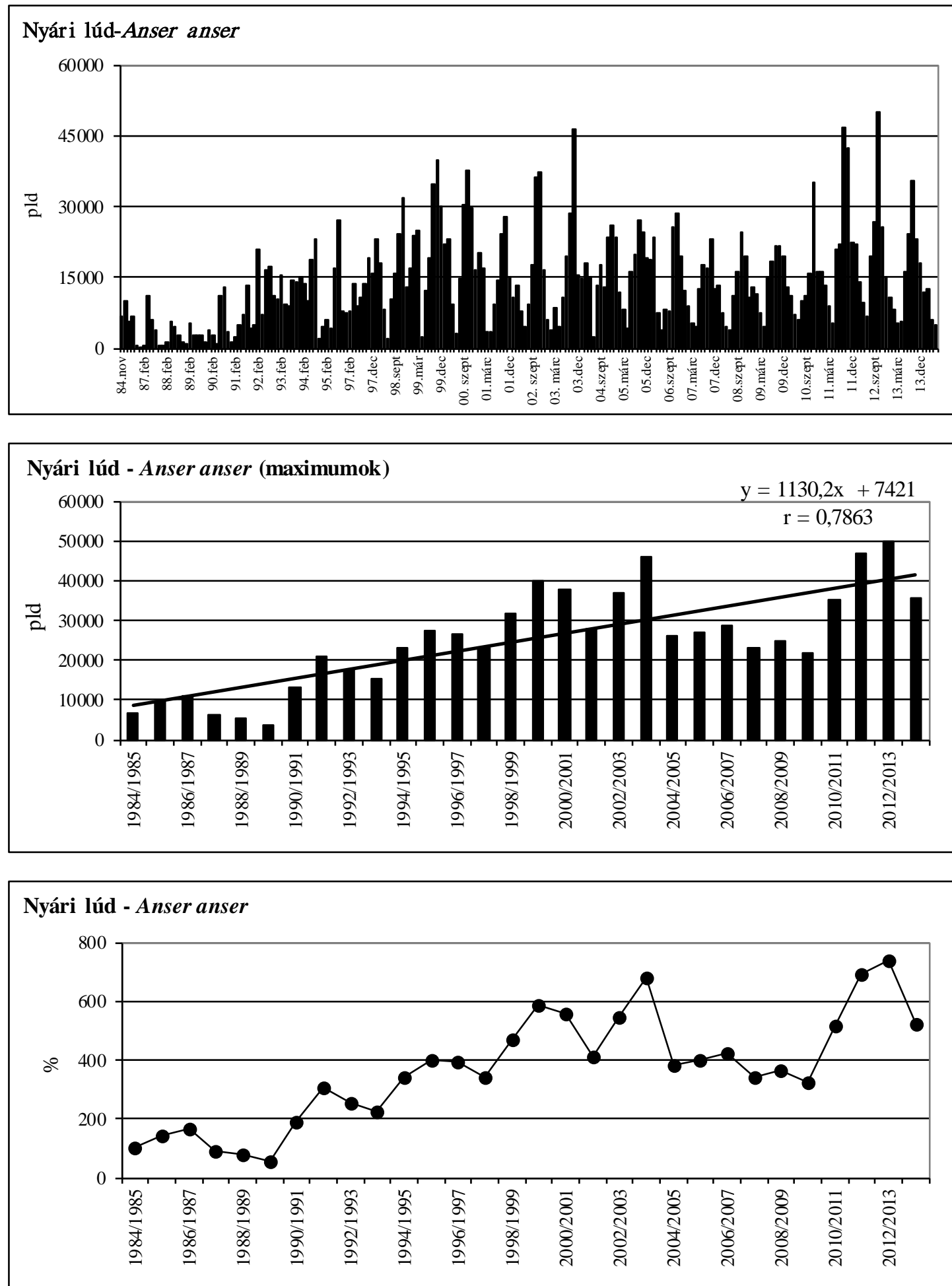

11. ábra: A nyári lúd havi dinamikája, éves maximumának trendje és éves maximumindexe Magyarországon, 1984-2014

Figure 11: Monthly dynamics, trends of yearly maximums and maximum indices for Greylag Goose in Hungary, 1984-2014 
26. táblázat: A kanadai lúd dinamikája Magyarországon, 2013/2014.

Table 26: Dynamics of Branta canadensis in Hungary, 2013/2014.

\begin{tabular}{|c|c|c|c|c|c|c|c|c|c|}
\hline Kanadai lúd (Branta canadensis) & Aug & Sept & Oct & Nov & Dec & Jan & Feb & Mar & April \\
\hline $\begin{array}{l}\text { Fertő-tó } \\
\text { Lake Fertő }\end{array}$ & 0 & 0 & 0 & 0 & 0 & 0 & 0 & 0 & 0 \\
\hline $\begin{array}{l}\text { Kis-Balaton } \\
\text { Kis-Balaton }\end{array}$ & 0 & 0 & 0 & 0 & 0 & 0 & 0 & 0 & 0 \\
\hline $\begin{array}{l}\text { Kelet-Balaton } \\
\text { Lake Balaton-East }\end{array}$ & 0 & 0 & 0 & 0 & 0 & 0 & 0 & 0 & 0 \\
\hline $\begin{array}{l}\text { Tatai Öreg-tó } \\
\text { Old Lake at Tata }\end{array}$ & 0 & 0 & 0 & 0 & 0 & 0 & 0 & 0 & 0 \\
\hline $\begin{array}{l}\text { Velencei-tó és Dinnyési Fertő } \\
\text { Lake Velence and Dinnyési Fertő }\end{array}$ & 0 & 0 & 0 & 0 & 0 & 0 & 0 & 0 & 0 \\
\hline $\begin{array}{l}\text { Soponyai-halastavak } \\
\text { Fishponds at Soponya } \\
\end{array}$ & 0 & 0 & 0 & 0 & 0 & 1 & 0 & 0 & 0 \\
\hline $\begin{array}{l}\text { Rétszilasi-halastavak } \\
\text { Fishponds at Rétszilas }\end{array}$ & 0 & 0 & 0 & 0 & 0 & 0 & 0 & 0 & 0 \\
\hline $\begin{array}{l}\text { Dráva Barcs-Szentborbás } \\
\text { River Dráva: Barcs-Szentborbás }\end{array}$ & 0 & 0 & 0 & 0 & 0 & 0 & 0 & 0 & 0 \\
\hline $\begin{array}{l}\text { Pellérdi-halastavak } \\
\text { Fishponds at Pellérd } \\
\end{array}$ & 0 & 0 & 0 & 0 & 0 & 0 & 0 & 0 & 0 \\
\hline $\begin{array}{l}\text { Sumonyi-halastavak } \\
\text { Fishponds at Sumony } \\
\end{array}$ & 0 & 0 & 0 & 0 & 0 & 0 & 0 & 0 & 0 \\
\hline $\begin{array}{l}\text { Duna Gönyü-Szob } \\
\text { River Danube: Gönyü - Szob }\end{array}$ & 0 & 0 & 0 & 0 & 0 & 0 & 0 & 0 & 0 \\
\hline $\begin{array}{l}\text { Duna Gemenc } \\
\text { River Danube at Gemenc } \\
\end{array}$ & 0 & 0 & 0 & 0 & 0 & 0 & 0 & 0 & 0 \\
\hline $\begin{array}{l}\text { Duna Karapancsa } \\
\text { River Danube at Karapancsa } \\
\end{array}$ & 0 & 0 & 0 & 0 & 0 & 0 & 0 & 0 & 0 \\
\hline $\begin{array}{l}\text { Kiskunsági szikes tavak } \\
\text { Natron lakes in Kiskunság } \\
\end{array}$ & 0 & 0 & 0 & 0 & 0 & 0 & 0 & 0 & 0 \\
\hline $\begin{array}{l}\text { Tömörkényi Csaj-tó } \\
\text { Lake Csaj at Tömörkény }\end{array}$ & 0 & 0 & 0 & 0 & 0 & 0 & 0 & 0 & 0 \\
\hline $\begin{array}{l}\text { Szegedi Fehér-tó és Fertő } \\
\text { Lake Fehér and Fertő at Szeged }\end{array}$ & 0 & 0 & 0 & 0 & 0 & 0 & 0 & 0 & 0 \\
\hline $\begin{array}{l}\text { Tisza-tó } \\
\text { Lake Tisza } \\
\end{array}$ & 0 & 0 & 0 & 0 & 0 & 0 & 0 & 0 & 0 \\
\hline $\begin{array}{l}\text { Hortobágy } \\
\text { Hortobágy }\end{array}$ & 0 & 0 & 0 & 0 & 0 & 0 & 0 & 0 & 0 \\
\hline $\begin{array}{l}\text { Biharugrai és Begécsi halastavak } \\
\text { Fishponds at Biharugra and Begécs }\end{array}$ & 0 & 0 & 0 & 0 & 0 & 0 & 0 & 0 & 0 \\
\hline $\begin{array}{l}\text { Kardoskúti Fehér-tó } \\
\text { Lake Fehér at Kardoskút }\end{array}$ & 0 & 0 & 0 & 0 & 0 & 0 & 0 & 0 & 0 \\
\hline $\begin{array}{l}\text { Magyar or szág összesen } \\
\text { Hungary total }\end{array}$ & 0 & 0 & 0 & 0 & 0 & 1 & 0 & 0 & 0 \\
\hline
\end{tabular}




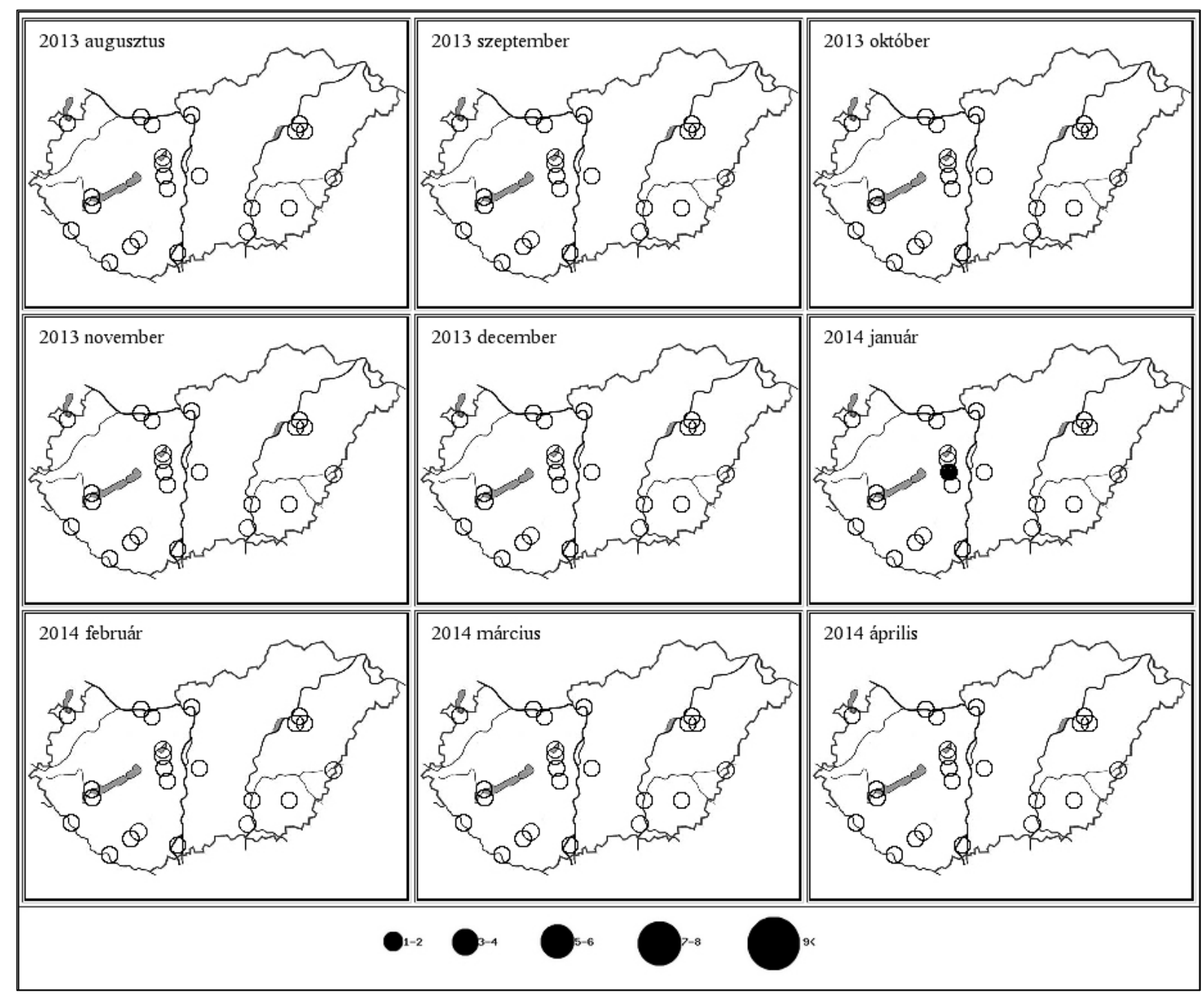

5. térkép: A kanadai lúd előfordulás havi mintázata Magyarországon, 2013/2014

Map 5: Monthly distribution pattern of Canada Goose in Hungary, 2013/2014 
27. táblázat: Az apácalúd dinamikája Magyarországon, 2013/2014.

Table 27: Dynamics of Branta leucopsis in Hungary, 2013/2014.

\begin{tabular}{|c|c|c|c|c|c|c|c|c|c|}
\hline Apácalúd (Branta leucopsis) & Aug & Sept & Oct & Nov & Dec & Jan & Feb & Mar & April \\
\hline $\begin{array}{l}\text { Fertő-tó } \\
\text { Lake Fertő }\end{array}$ & 0 & 0 & 0 & 0 & 0 & 0 & 2 & 0 & 0 \\
\hline $\begin{array}{l}\text { Kis-Balaton } \\
\text { Kis-Balaton }\end{array}$ & 0 & 0 & 0 & 0 & 1 & 0 & 0 & 0 & 0 \\
\hline $\begin{array}{l}\text { Kelet-Balaton } \\
\text { Lake Balaton-East }\end{array}$ & 0 & 0 & 0 & 0 & 0 & 0 & 0 & 0 & 0 \\
\hline $\begin{array}{l}\text { Tatai Öreg-tó } \\
\text { Old Lake at Tata }\end{array}$ & 0 & 0 & 0 & 0 & 1 & 1 & 0 & 0 & 0 \\
\hline $\begin{array}{l}\text { Velencei-tó és Dinnyési Fertő } \\
\text { Lake Velence and Dinnyési Fertő }\end{array}$ & 0 & 0 & 0 & 2 & 2 & 0 & 0 & 0 & 0 \\
\hline $\begin{array}{l}\text { Soponyai-halastavak } \\
\text { Fishponds at Soponya } \\
\end{array}$ & 0 & 0 & 0 & 0 & 0 & 0 & 0 & 0 & 0 \\
\hline $\begin{array}{l}\text { Rétszilasi-halastavak } \\
\text { Fishponds at Rétszilas }\end{array}$ & 0 & 0 & 0 & 0 & 0 & 0 & 0 & 0 & 0 \\
\hline $\begin{array}{l}\text { Dráva Barcs-Szentborbás } \\
\text { River Dráva: Barcs-Szentborbás }\end{array}$ & 0 & 0 & 0 & 0 & 0 & 0 & 0 & 0 & 0 \\
\hline $\begin{array}{l}\text { Pellérdi-halastavak } \\
\text { Fishponds at Pellérd } \\
\end{array}$ & 0 & 0 & 0 & 0 & 0 & 0 & 0 & 0 & 0 \\
\hline $\begin{array}{l}\text { Sumonyi-halastavak } \\
\text { Fishponds at Sumony }\end{array}$ & 0 & 0 & 0 & 0 & 0 & 0 & 0 & 0 & 0 \\
\hline $\begin{array}{l}\text { Duna Gönyü-Szob } \\
\text { River Danube: Gönyü - Szob }\end{array}$ & 0 & 0 & 0 & 0 & 0 & 0 & 0 & 0 & 0 \\
\hline $\begin{array}{l}\text { Duna Gemenc } \\
\text { River Danube at Gemenc } \\
\end{array}$ & 0 & 0 & 0 & 0 & 0 & 0 & 0 & 0 & 0 \\
\hline $\begin{array}{l}\text { Duna Karapancsa } \\
\text { River Danube at Karapancsa } \\
\end{array}$ & 0 & 0 & 0 & 0 & 0 & 0 & 0 & 0 & 0 \\
\hline $\begin{array}{l}\text { Kiskunsági szikes tavak } \\
\text { Natron lakes in Kiskunság } \\
\end{array}$ & 0 & 0 & 0 & 0 & 0 & 0 & 0 & 0 & 0 \\
\hline $\begin{array}{l}\text { Tömörkényi Csaj-tó } \\
\text { Lake Csaj at Tömörkény }\end{array}$ & 0 & 0 & 0 & 0 & 0 & 0 & 0 & 3 & 0 \\
\hline $\begin{array}{l}\text { Szegedi Fehér-tó és Fertő } \\
\text { Lake Fehér and Fertő at Szeged }\end{array}$ & 0 & 0 & 0 & 0 & 0 & 0 & 0 & 0 & 0 \\
\hline $\begin{array}{l}\text { Tisza-tó } \\
\text { Lake Tisza } \\
\end{array}$ & 0 & 0 & 0 & 0 & 0 & 0 & 0 & 0 & 0 \\
\hline $\begin{array}{l}\text { Hortobágy } \\
\text { Hortobágy }\end{array}$ & 0 & 0 & 1 & 0 & 0 & 0 & 0 & 0 & 0 \\
\hline $\begin{array}{l}\text { Biharugrai és Begécsi halastavak } \\
\text { Fishponds at Biharugra and Begécs }\end{array}$ & 0 & 0 & 0 & 0 & 0 & 0 & 0 & 0 & 0 \\
\hline $\begin{array}{l}\text { Kardoskúti Fehér-tó } \\
\text { Lake Fehér at Kardoskút }\end{array}$ & 0 & 0 & 0 & 0 & 0 & 0 & 0 & 0 & 0 \\
\hline $\begin{array}{l}\text { Magyar or szág összesen } \\
\text { Hungary total }\end{array}$ & 0 & 0 & 1 & 2 & 4 & 1 & 2 & 3 & 0 \\
\hline
\end{tabular}




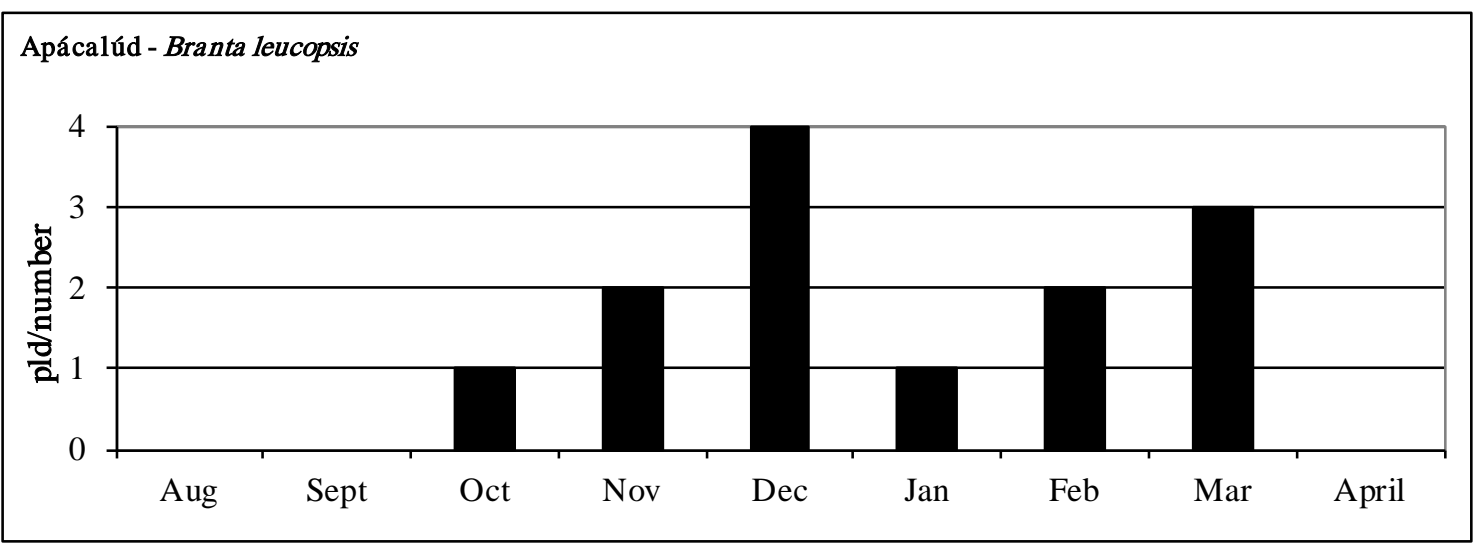

12. ábra: Apácalúd -Magyarország összesen, 2013/2014.

Figure 2: Branta leucopsis - Hungary total, 2013/2014.

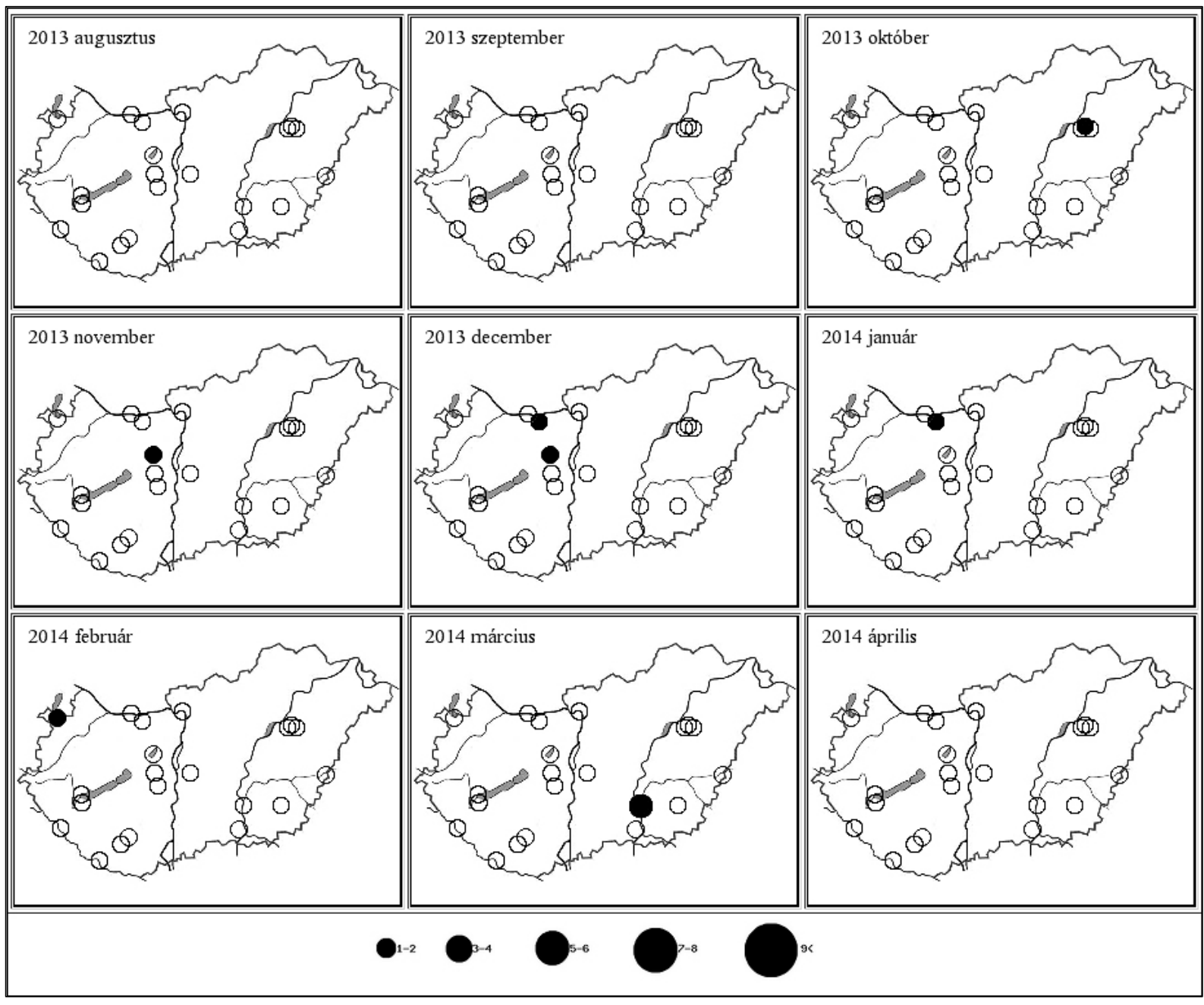

6. térkép: Az apácalúd előfordulás havi mintázata Magyarországon, 2013/2014

Map 6: Monthly distribution pattern of Barnacle Goose in Hungary, 2013/2014 

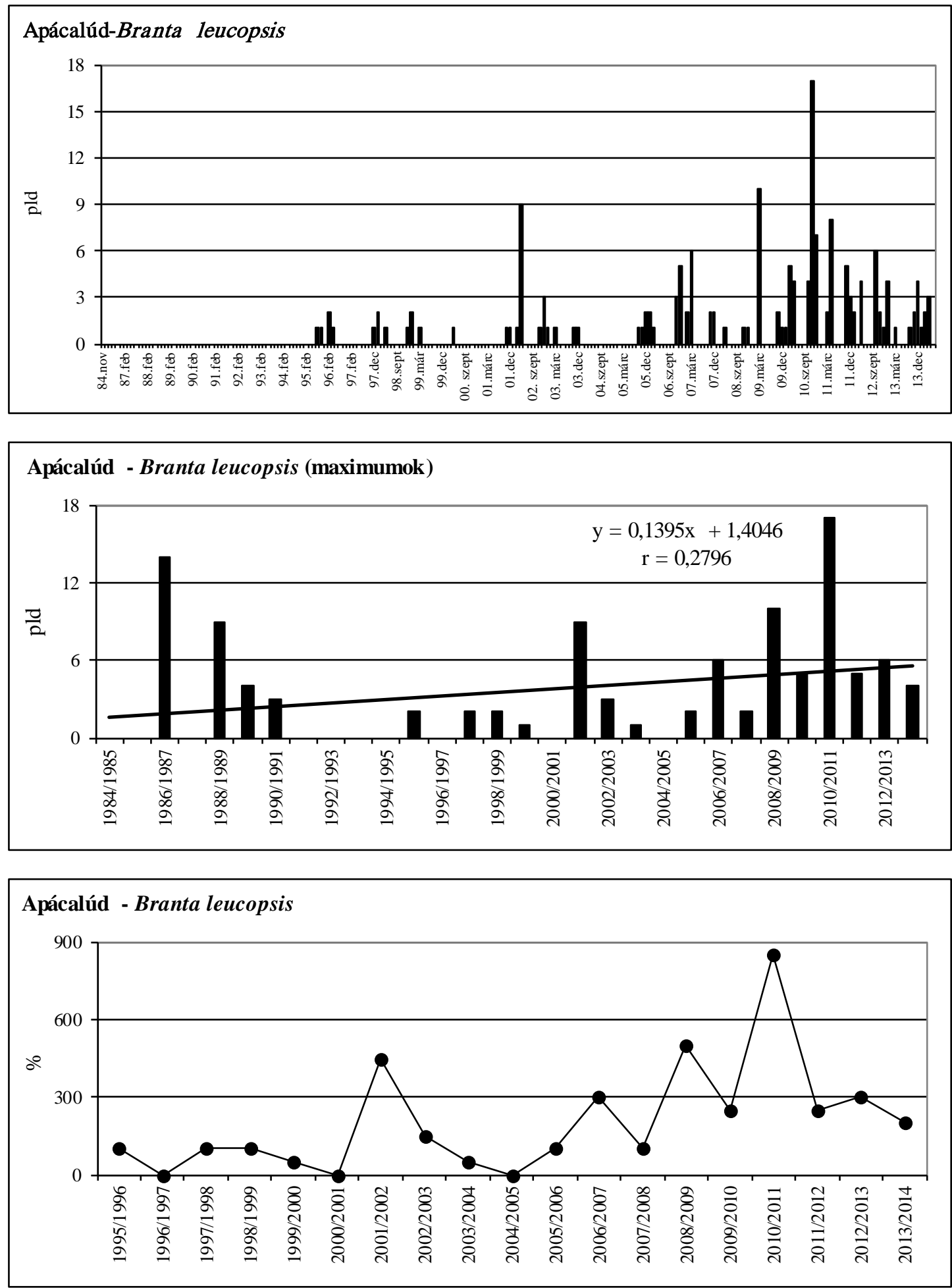

13. ábra: Az apácalúd havi dinamikája, éves maximumának trendje és éves maximumindexe Magyarországon, 1984-2014

Figure 13: Monthly dynamics, trend of yearly maximums and maximum indices for Barnacle Goose in Hungary, 1984-2014 
28. táblázat: Az örvös lúd dinamikája Magyarországon, 2013/2014.

Table 28: Dynamics of Branta bernicla in Hungary, 2013/2014.

\begin{tabular}{|c|c|c|c|c|c|c|c|c|c|}
\hline Örvös lúd (Branta bernicla) & Aug & Sept & Oct & Nov & Dec & Jan & Feb & Mar & April \\
\hline $\begin{array}{l}\text { Fertő-tó } \\
\text { Lake Fertő }\end{array}$ & 0 & 0 & 0 & 0 & 0 & 0 & 0 & 0 & 0 \\
\hline $\begin{array}{l}\text { Kis-Balaton } \\
\text { Kis-Balaton }\end{array}$ & 0 & 0 & 0 & 0 & 0 & 0 & 0 & 0 & 0 \\
\hline $\begin{array}{l}\text { Kelet-Balaton } \\
\text { Lake Balaton-East }\end{array}$ & 0 & 0 & 0 & 0 & 0 & 0 & 0 & 0 & 0 \\
\hline $\begin{array}{l}\text { Tatai Öreg-tó } \\
\text { Old Lake at Tata }\end{array}$ & 0 & 0 & 0 & 0 & 0 & 0 & 0 & 0 & 0 \\
\hline $\begin{array}{l}\text { Velencei-tó és Dinnyési Fertő } \\
\text { Lake Velence and Dinnyési Fertő }\end{array}$ & 0 & 0 & 0 & 2 & 0 & 0 & 0 & 0 & 0 \\
\hline \begin{tabular}{|l|} 
Soponyai-halastavak \\
Fishponds at Soponya \\
\end{tabular} & 0 & 0 & 0 & 0 & 0 & 1 & 0 & 0 & 0 \\
\hline $\begin{array}{l}\text { Rétszilasi-halastavak } \\
\text { Fishponds at Rétszilas }\end{array}$ & 0 & 0 & 0 & 0 & 0 & 0 & 0 & 0 & 0 \\
\hline $\begin{array}{l}\text { Dráva Barcs-Szentborbás } \\
\text { River Dráva: Barcs-Szentborbás }\end{array}$ & 0 & 0 & 0 & 0 & 0 & 0 & 0 & 0 & 0 \\
\hline $\begin{array}{l}\text { Pellérdi-halastavak } \\
\text { Fishponds at Pellérd }\end{array}$ & 0 & 0 & 0 & 0 & 0 & 0 & 0 & 0 & 0 \\
\hline $\begin{array}{l}\text { Sumonyi-halastavak } \\
\text { Fishponds at Sumony } \\
\end{array}$ & 0 & 0 & 0 & 0 & 0 & 0 & 0 & 0 & 0 \\
\hline $\begin{array}{l}\text { Duna Gönyü-Szob } \\
\text { River Danube: Gönyü - Szob }\end{array}$ & 0 & 0 & 0 & 0 & 0 & 0 & 0 & 0 & 0 \\
\hline $\begin{array}{l}\text { Duna Gemenc } \\
\text { River Danube at Gemenc }\end{array}$ & 0 & 0 & 0 & 0 & 0 & 1 & 1 & 0 & 0 \\
\hline $\begin{array}{l}\text { Duna Karapancsa } \\
\text { River Danube at Karapancsa }\end{array}$ & 0 & 0 & 0 & 0 & 1 & 0 & 0 & 0 & 0 \\
\hline $\begin{array}{l}\text { Kiskunsági szikes tavak } \\
\text { Natron lakes in Kiskunság }\end{array}$ & 0 & 0 & 1 & 0 & 0 & 0 & 0 & 0 & 0 \\
\hline $\begin{array}{l}\text { Tömörkényi Csaj-tó } \\
\text { Lake Csaj at Tömörkény }\end{array}$ & 0 & 0 & 0 & 0 & 0 & 0 & 0 & 0 & 0 \\
\hline $\begin{array}{l}\text { Szegedi Fehér-tó és Fertő } \\
\text { Lake Fehér and Fertő at Szeged }\end{array}$ & 0 & 0 & 0 & 0 & 0 & 0 & 0 & 0 & 0 \\
\hline $\begin{array}{l}\text { Tisza-tó } \\
\text { Lake Tisza }\end{array}$ & 0 & 0 & 0 & 0 & 0 & 0 & 0 & 0 & 0 \\
\hline $\begin{array}{l}\text { Hortobágy } \\
\text { Hortobágy }\end{array}$ & 0 & 0 & 0 & 0 & 0 & 0 & 0 & 0 & 0 \\
\hline $\begin{array}{l}\text { Biharugrai és Begécsi halastavak } \\
\text { Fishponds at Biharugra and Begécs }\end{array}$ & 0 & 0 & 0 & 0 & 0 & 0 & 0 & 0 & 0 \\
\hline $\begin{array}{l}\text { Kardoskúti Fehér-tó } \\
\text { Lake Fehér at Kardoskút }\end{array}$ & 0 & 0 & 0 & 0 & 0 & 0 & 0 & 0 & 0 \\
\hline $\begin{array}{l}\text { Magyar or szág összesen } \\
\text { Hungary total }\end{array}$ & 0 & 0 & 1 & 2 & 1 & 2 & 1 & 0 & 0 \\
\hline
\end{tabular}




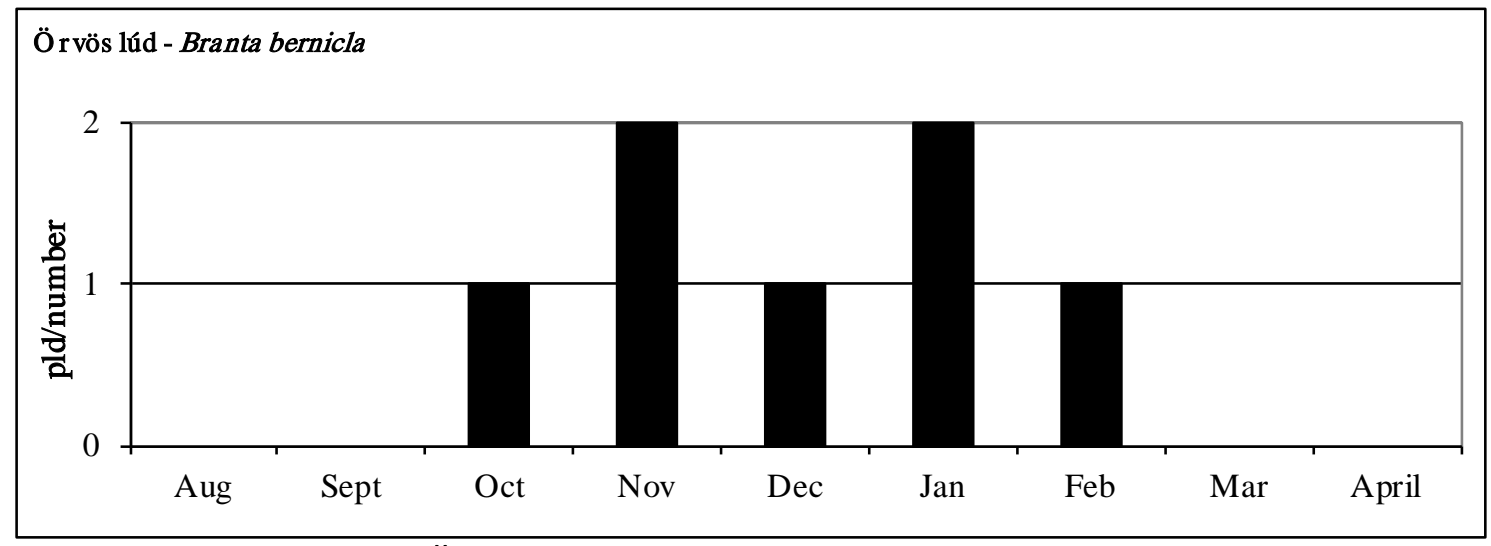

14. ábra: Örvös lúd -Magyarország összesen, 2013/2014.

Figure 14: Branta bernicla - Hungary total, 2013/2014.

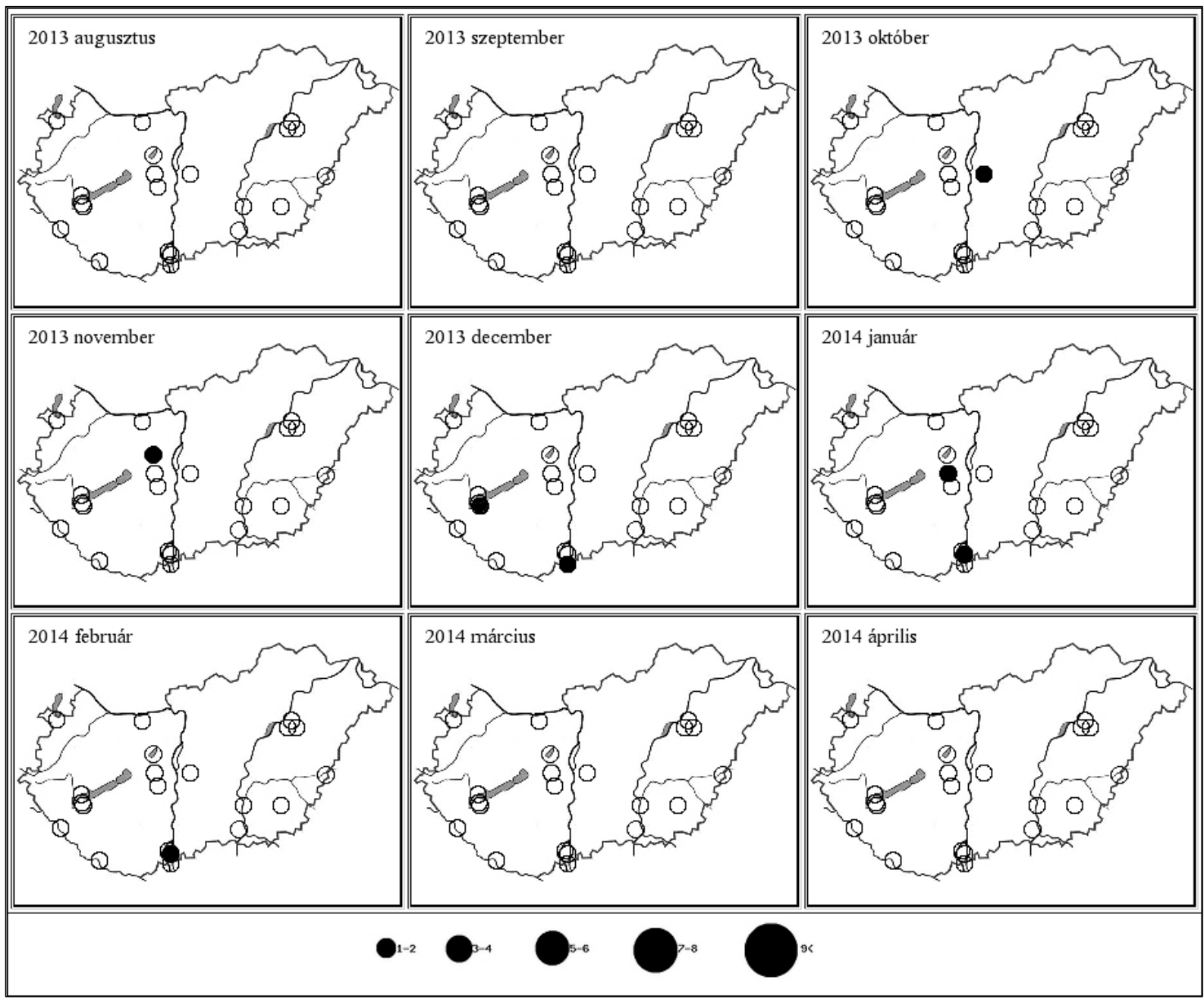

7. térkép: Az örvös lúd előfordulás havi mintázata Magyarországon, 2013/2014

Map 7: Monthly distribution pattern of Brent Goose in Hungary, 2013/2014 

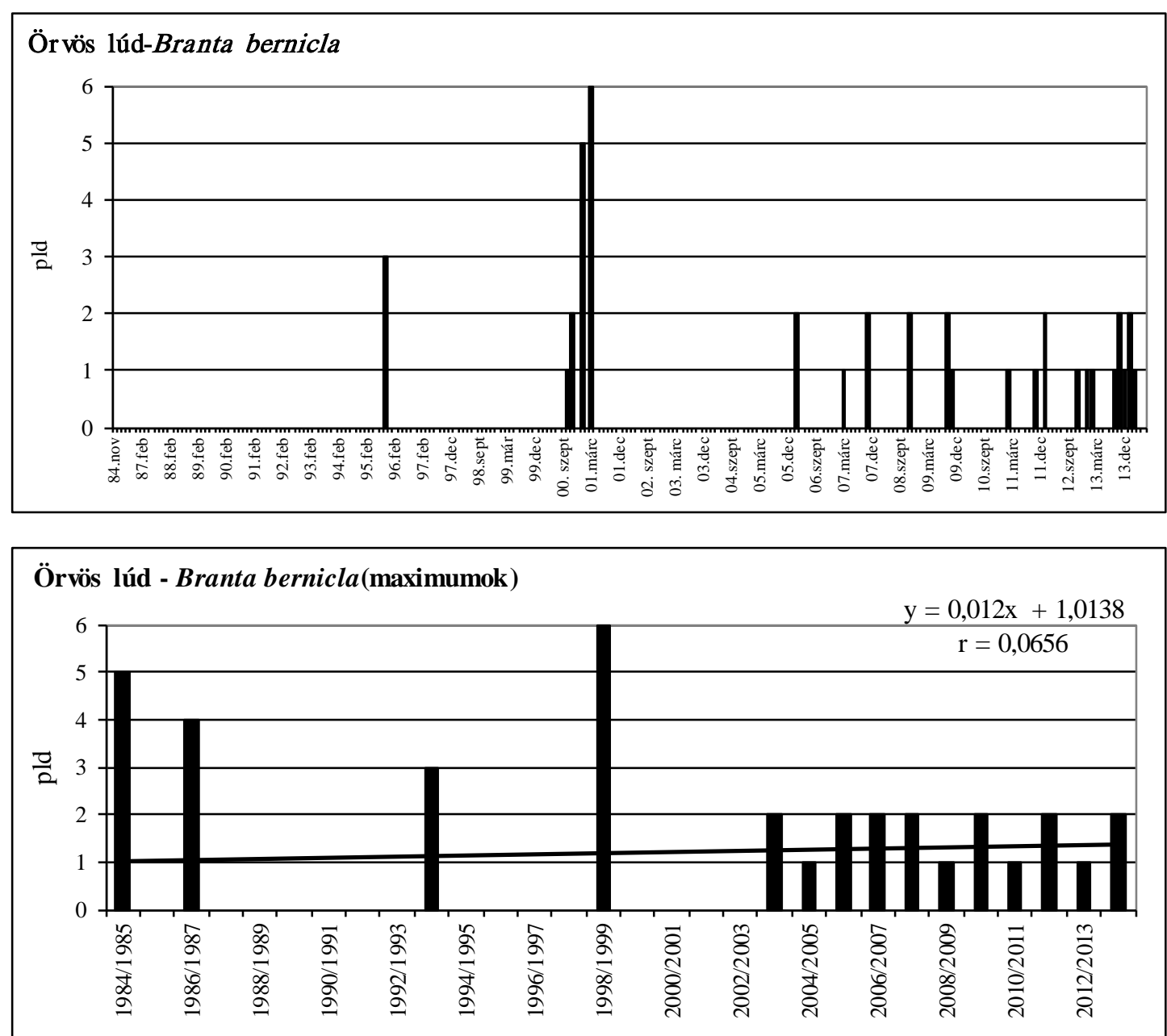

15. ábra: Az örvös lúd havi dinamikája, és éves maximumának trendje Magyarországon, 1984-2014

Figure 15: Monthly dynamics and trend of yearly maximums for Brent Goose in Hungary, 1984-2014 
29. táblázat: A vörösnyakú lúd dinamikája Magyarországon, 2013/2014.

Table 29: Dynamics of Branta ruficollis in Hungary, 2013/2014.

\begin{tabular}{|c|c|c|c|c|c|c|c|c|c|}
\hline Vörösnyakú lúd (Branta ruficollis) & Aug & Sept & Oct & Nov & Dec & Jan & Feb & Mar & April \\
\hline $\begin{array}{l}\text { Fertő-tó } \\
\text { Lake Fertő }\end{array}$ & 0 & 0 & 0 & 0 & 6 & 1 & 0 & 0 & 0 \\
\hline $\begin{array}{l}\text { Kis-Balaton } \\
\text { Kis-Balaton }\end{array}$ & 0 & 0 & 0 & 0 & 0 & 0 & 0 & 0 & 0 \\
\hline $\begin{array}{l}\text { Kelet-Balaton } \\
\text { Lake Balaton-East }\end{array}$ & 0 & 0 & 0 & 0 & 0 & 0 & 0 & 0 & 0 \\
\hline $\begin{array}{l}\text { Tatai Öreg-tó } \\
\text { Old Lake at Tata }\end{array}$ & 0 & 0 & 0 & 24 & 10 & 6 & 0 & 0 & 0 \\
\hline $\begin{array}{l}\text { Velencei-tó és Dinnyési Fertő } \\
\text { Lake Velence and Dinnyési Fertő }\end{array}$ & 0 & 0 & 0 & 14 & 3 & 11 & 16 & 0 & 0 \\
\hline $\begin{array}{l}\text { Soponyai-halastavak } \\
\text { Fishponds at Soponya } \\
\end{array}$ & 0 & 0 & 0 & 3 & 3 & 1 & 0 & 0 & 0 \\
\hline $\begin{array}{l}\text { Rétszilasi-halastavak } \\
\text { Fishponds at Rétszilas }\end{array}$ & 0 & 0 & 0 & 1 & 0 & 0 & 0 & 0 & 0 \\
\hline $\begin{array}{l}\text { Dráva Barcs-Szentborbás } \\
\text { River Dráva: Barcs-Szentborbás } \\
\end{array}$ & 0 & 0 & 0 & 0 & 0 & 0 & 0 & 0 & 0 \\
\hline $\begin{array}{l}\text { Pellérdi-halastavak } \\
\text { Fishponds at Pellérd } \\
\end{array}$ & 0 & 0 & 0 & 0 & 0 & 0 & 0 & 0 & 0 \\
\hline $\begin{array}{l}\text { Sumonyi-halastavak } \\
\text { Fishponds at Sumony } \\
\end{array}$ & 0 & 0 & 0 & 0 & 0 & 0 & 0 & 0 & 0 \\
\hline $\begin{array}{l}\text { Duna Gönyü-Szob } \\
\text { River Danube: Gönyü - Szob }\end{array}$ & 0 & 0 & 0 & 0 & 0 & 0 & 0 & 0 & 0 \\
\hline $\begin{array}{l}\text { Duna Gemenc } \\
\text { River Danube at Gemenc } \\
\end{array}$ & 0 & 0 & 0 & 0 & 0 & 0 & 0 & 0 & 0 \\
\hline $\begin{array}{l}\text { Duna Karapancsa } \\
\text { River Danube at Karapancsa } \\
\end{array}$ & 0 & 0 & 0 & 0 & 0 & 0 & 0 & 0 & 0 \\
\hline $\begin{array}{l}\text { Kiskunsági szikes tavak } \\
\text { Natron lakes in Kiskunság } \\
\end{array}$ & 0 & 0 & 0 & 5 & 0 & 0 & 0 & 0 & 0 \\
\hline $\begin{array}{l}\text { Tömörkényi Csaj-tó } \\
\text { Lake Csaj at Tömörkény }\end{array}$ & 0 & 0 & 0 & 8 & 3 & 0 & 0 & 9 & 0 \\
\hline $\begin{array}{l}\text { Szegedi Fehér-tó és Fertő } \\
\text { Lake Fehér and Fertő at Szeged }\end{array}$ & 0 & 0 & 0 & 0 & 0 & 0 & 0 & 0 & 0 \\
\hline $\begin{array}{l}\text { Tisza-tó } \\
\text { Lake Tisza }\end{array}$ & 0 & 0 & 1 & 0 & 0 & 0 & 0 & 0 & 0 \\
\hline $\begin{array}{l}\text { Hortobágy } \\
\text { Hortobágy }\end{array}$ & 0 & 0 & 1 & 0 & 9 & 113 & 75 & 50 & 0 \\
\hline $\begin{array}{l}\text { Biharugrai és Begécsi halastavak } \\
\text { Fishponds at Biharugra and Begécs }\end{array}$ & 0 & 0 & 0 & 31 & 8 & 7 & 12 & 0 & 0 \\
\hline $\begin{array}{l}\text { Kardoskúti Fehér-tó } \\
\text { Lake Fehér at Kardoskút }\end{array}$ & 0 & 0 & 0 & 0 & 0 & 0 & 0 & 0 & 0 \\
\hline $\begin{array}{l}\text { Magyar or szág összesen } \\
\text { Hungary total }\end{array}$ & 0 & 0 & 2 & 86 & 42 & 139 & 103 & 59 & 0 \\
\hline
\end{tabular}




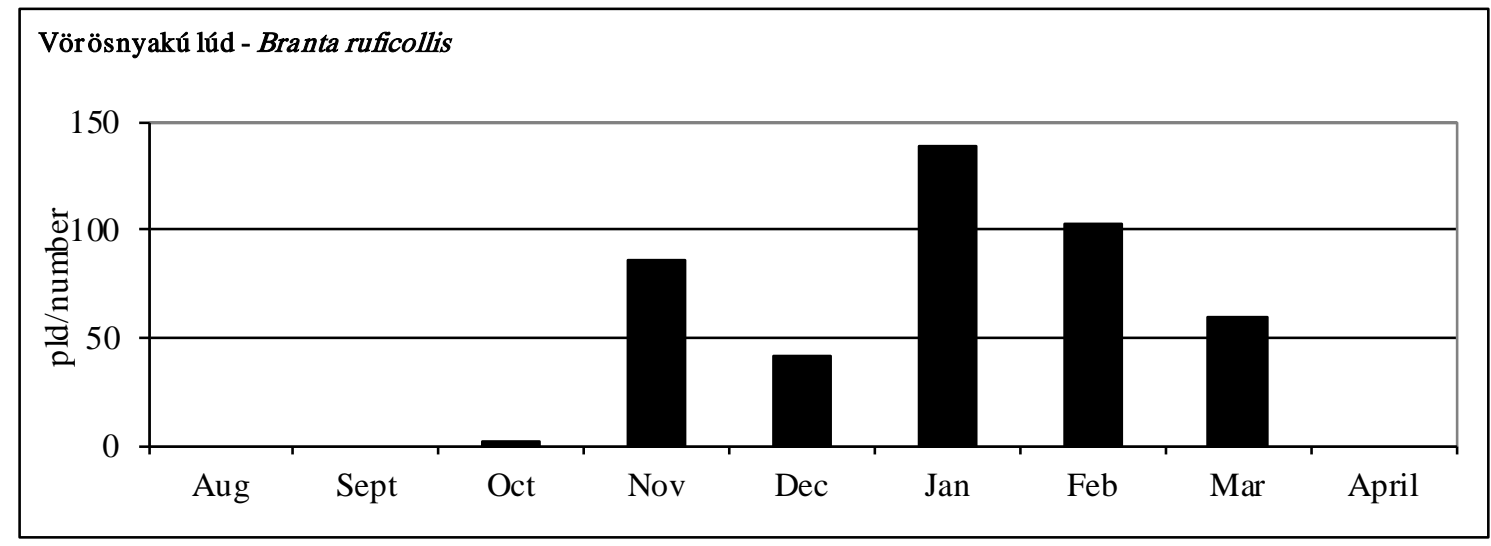

16. ábra: Vörösnyakú lúd -Magyarország összesen, 2013/2014.

Figure 16: Branta ruficollis - Hungary total, 2013/2014.

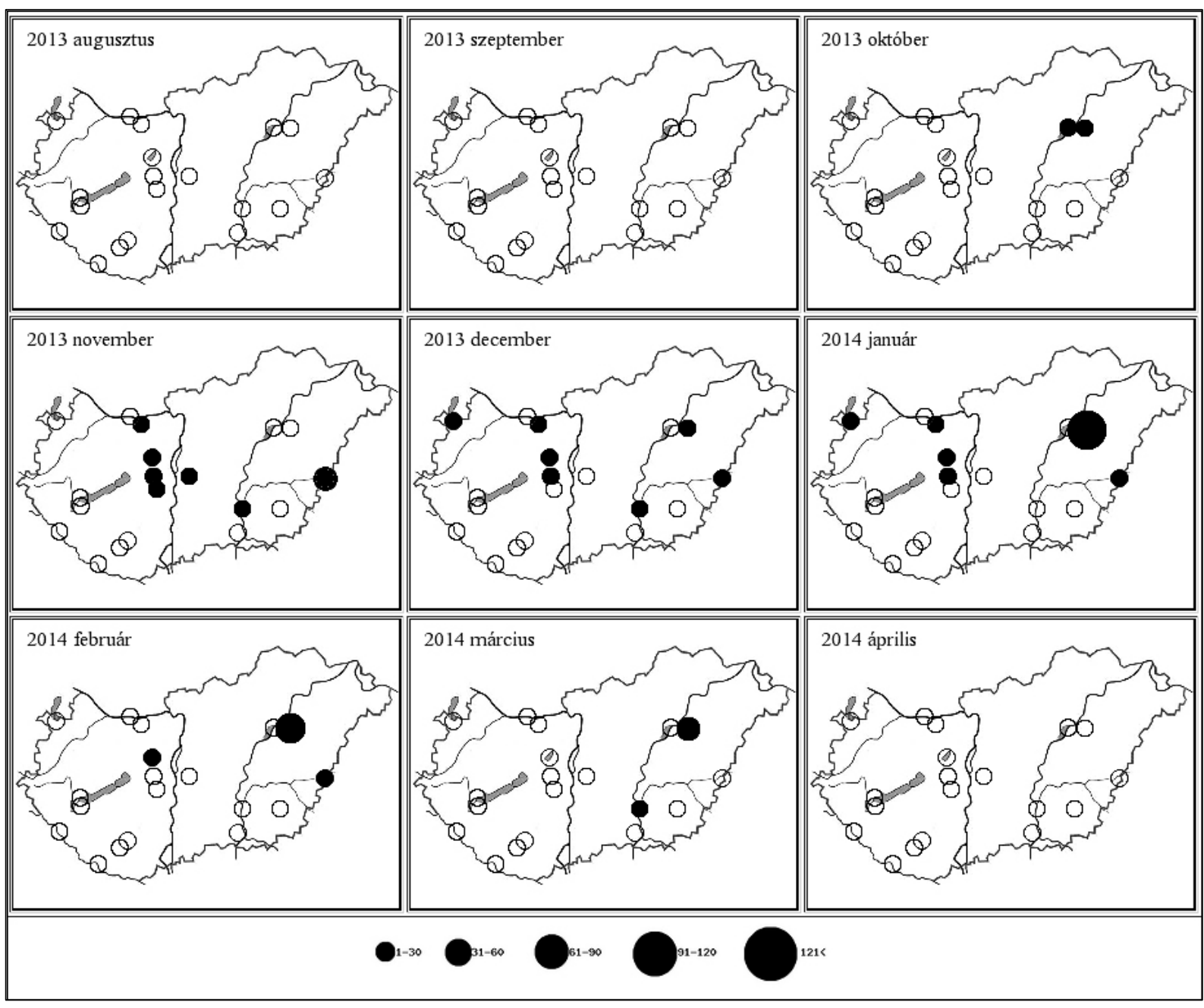

8. térkép: A vörösnyakú lúd előfordulás havi mintázata Magyarországon, 2013/2014

Map 8: Monthly distribution pattern of Red-breasted Goose in Hungary, 2013/2014 


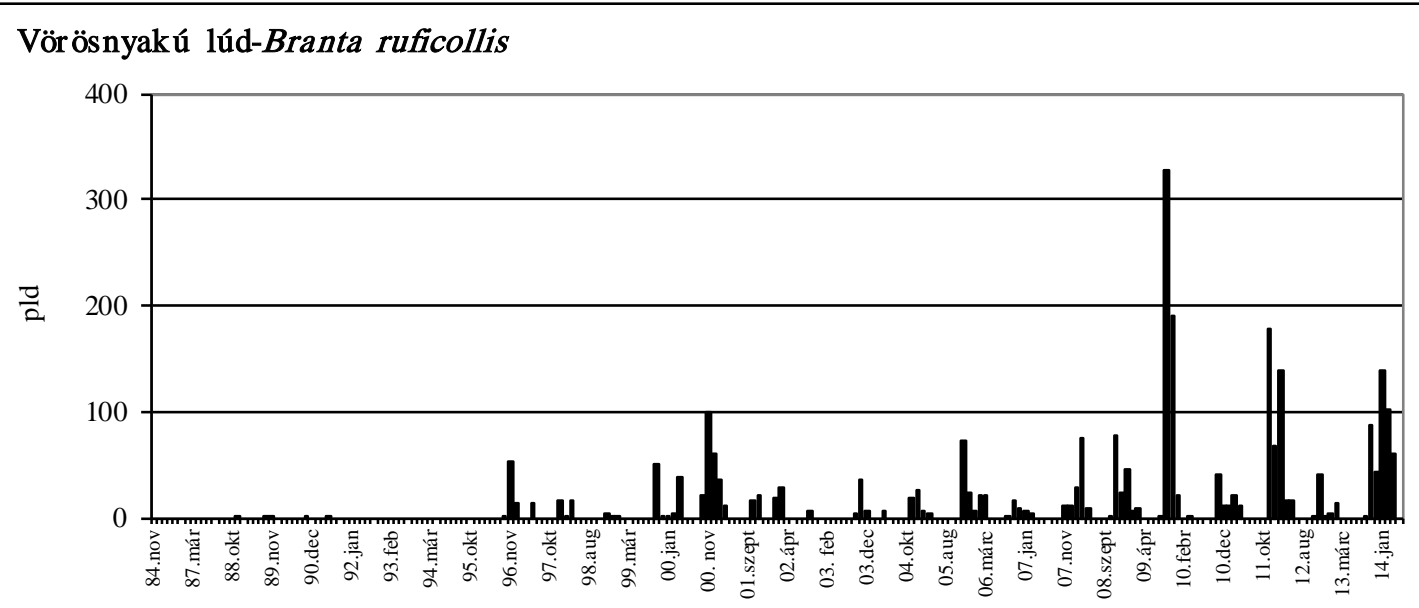

Vörösnyakú lúd - Branta ruficollis (maximumok)
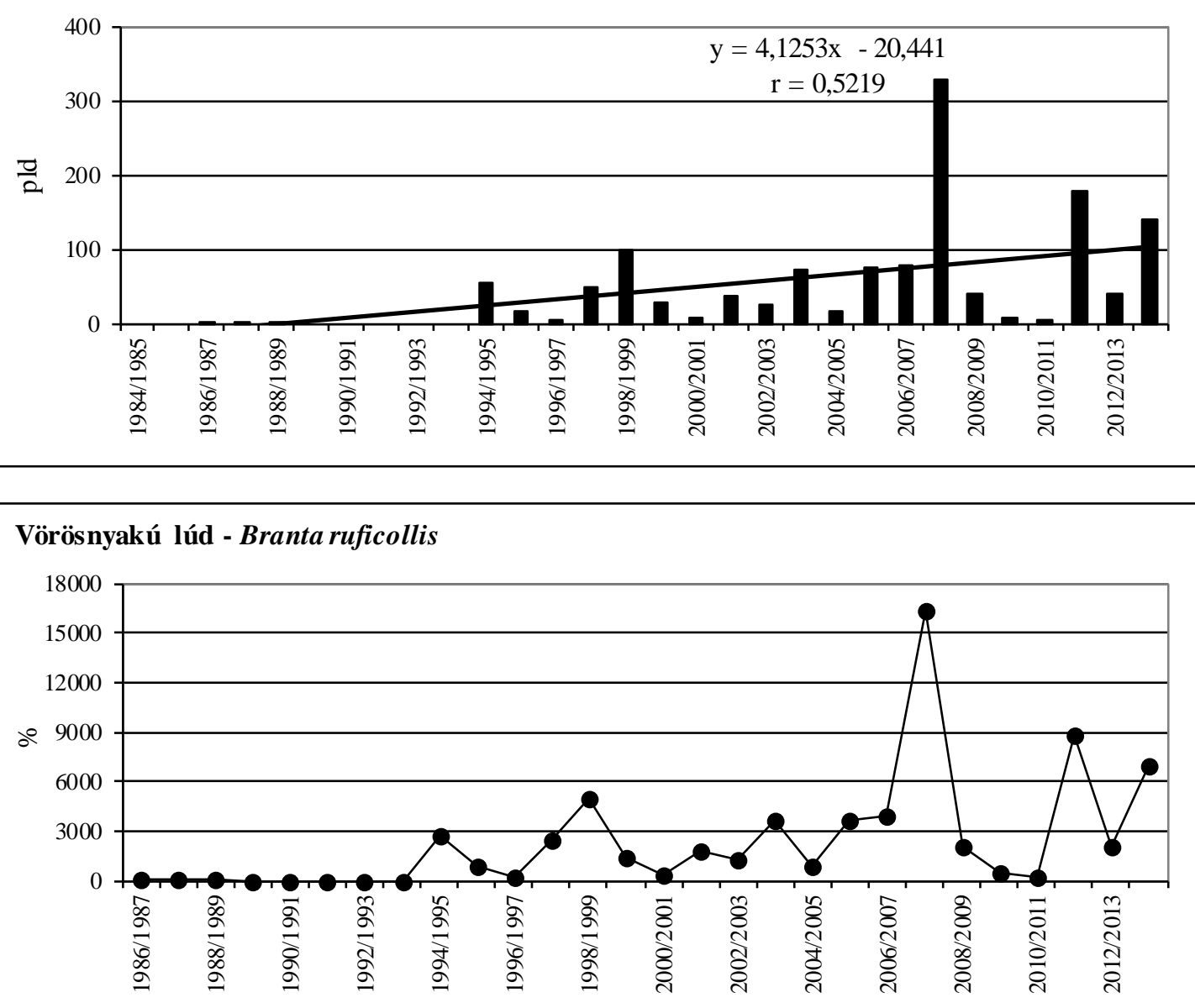

17. ábra: A vörösnyakú lúd havi dinamikája, éves maximumának trendje és éves maximum-indexe Magyarországon, 1984-2014

Figure 17: Monthly dynamics, trend of yearly maximums and maximum indices for Red-breasted Goose in Hungary, 1984-2014 
30. táblázat: A nílusi lúd dinamikája Magyarországon, 2013/2014.

Table 30: Dynamics of Alopochen aegyptiaca in Hungary, 2013/2014.

\begin{tabular}{|c|c|c|c|c|c|c|c|c|c|}
\hline Nílusi lúd (Alopochen aegyptiaca) & Aug & Sept & Oct & Nov & Dec & Jan & Feb & Mar & April \\
\hline $\begin{array}{l}\text { Fertő-tó } \\
\text { Lake Fertő }\end{array}$ & 0 & 0 & 0 & 0 & 0 & 0 & 0 & 0 & 0 \\
\hline $\begin{array}{l}\text { Kis-Balaton } \\
\text { Kis-Balaton }\end{array}$ & 0 & 0 & 0 & 0 & 0 & 0 & 0 & 0 & 0 \\
\hline $\begin{array}{l}\text { Kelet-Balaton } \\
\text { Lake Balaton-East }\end{array}$ & 0 & 0 & 0 & 0 & 0 & 0 & 0 & 0 & 0 \\
\hline $\begin{array}{l}\text { Tatai Öreg-tó } \\
\text { Old Lake at Tata }\end{array}$ & 0 & 0 & 0 & 0 & 0 & 0 & 0 & 0 & 0 \\
\hline $\begin{array}{l}\text { Velencei-tó és Dinnyési Fertő } \\
\text { Lake Velence and Dinnyési Fertő }\end{array}$ & 0 & 0 & 0 & 0 & 0 & 0 & 0 & 0 & 0 \\
\hline $\begin{array}{l}\text { Soponyai-halastavak } \\
\text { Fishponds at Soponya }\end{array}$ & 0 & 0 & 0 & 0 & 0 & 0 & 0 & 0 & 0 \\
\hline $\begin{array}{l}\text { Rétszilasi-halastavak } \\
\text { Fishponds at Rétszilas }\end{array}$ & 0 & 0 & 0 & 0 & 0 & 0 & 0 & 0 & 0 \\
\hline $\begin{array}{l}\text { Dráva Barcs-Szentborbás } \\
\text { River Dráva: Barcs-Szentborbás }\end{array}$ & 0 & 0 & 0 & 0 & 0 & 0 & 0 & 0 & 0 \\
\hline $\begin{array}{l}\text { Pellérdi-halastavak } \\
\text { Fishponds at Pellérd } \\
\end{array}$ & 0 & 0 & 4 & 0 & 0 & 0 & 0 & 0 & 0 \\
\hline $\begin{array}{l}\text { Sumonyi-halastavak } \\
\text { Fishponds at Sumony } \\
\end{array}$ & 0 & 0 & 0 & 0 & 0 & 0 & 0 & 0 & 0 \\
\hline $\begin{array}{l}\text { Duna Gönyü-Szob } \\
\text { River Danube: Gönyü - Szob }\end{array}$ & 0 & 0 & 0 & 0 & 0 & 0 & 0 & 0 & 0 \\
\hline $\begin{array}{l}\text { Duna Gemenc } \\
\text { River Danube at Gemenc }\end{array}$ & 0 & 0 & 0 & 0 & 0 & 0 & 0 & 0 & 0 \\
\hline $\begin{array}{l}\text { Duna Karapancsa } \\
\text { River Danube at Karapancsa }\end{array}$ & 0 & 0 & 0 & 0 & 0 & 0 & 0 & 0 & 0 \\
\hline $\begin{array}{l}\text { Kiskunsági szikes tavak } \\
\text { Natron lakes in Kiskunság }\end{array}$ & 0 & 0 & 0 & 0 & 0 & 0 & 0 & 0 & 0 \\
\hline $\begin{array}{l}\text { Tömörkényi Csaj-tó } \\
\text { Lake Csaj at Tömörkény }\end{array}$ & 0 & 0 & 0 & 0 & 0 & 0 & 0 & 0 & 0 \\
\hline $\begin{array}{l}\text { Szegedi Fehér-tó és Fertő } \\
\text { Lake Fehér and Fertő at Szeged }\end{array}$ & 0 & 0 & 0 & 0 & 0 & 0 & 0 & 0 & 0 \\
\hline $\begin{array}{l}\text { Tisza-tó } \\
\text { Lake Tisza }\end{array}$ & 0 & 0 & 0 & 0 & 0 & 0 & 0 & 0 & 0 \\
\hline $\begin{array}{l}\text { Hortobágy } \\
\text { Hortobágy }\end{array}$ & 0 & 0 & 0 & 0 & 0 & 0 & 0 & 0 & 0 \\
\hline $\begin{array}{l}\text { Biharugrai és Begécsi halastavak } \\
\text { Fishponds at Biharugra and Begécs }\end{array}$ & 0 & 0 & 0 & 0 & 0 & 0 & 0 & 0 & 0 \\
\hline $\begin{array}{l}\text { Kardoskúti Fehér-tó } \\
\text { Lake Fehér at Kardoskút }\end{array}$ & 0 & 0 & 0 & 0 & 0 & 0 & 0 & 0 & 0 \\
\hline $\begin{array}{l}\text { Magyar or szág összesen } \\
\text { Hungary total }\end{array}$ & 0 & 0 & 4 & 0 & 0 & 0 & 0 & 0 & 0 \\
\hline
\end{tabular}




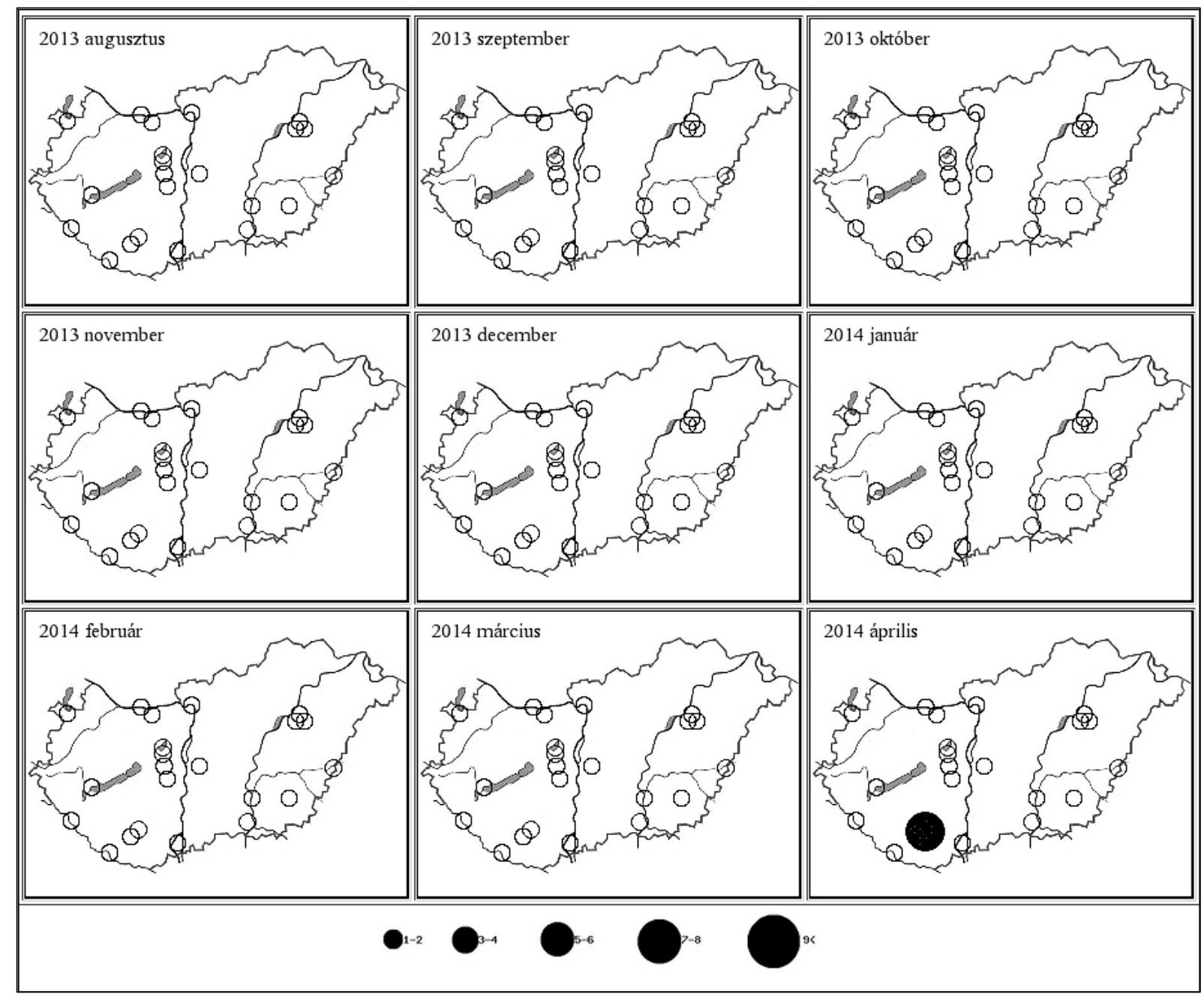

9. térkép: A nílusi lúd előfordulás havi mintázata Magyarországon, 2013/2014

Map 9: Monthly distribution pattern of Egyptian Goose in Hungary, 2013/2014 


\section{1. táblázat: A vadludak összesített dinamikája Magyarországon, 2013/2014.}

Table 31: Dynamics of total geese in Hungary, 2013/2014.

\begin{tabular}{|c|c|c|c|c|c|c|c|c|c|}
\hline Hely/Sites & Aug & Sept & Oct & Nov & Dec & $\mathrm{J}$ an & Feb & Mar & April \\
\hline $\begin{array}{l}\text { Fertő-tó } \\
\text { Lake Fertő }\end{array}$ & 200 & 1700 & 2851 & 9683 & 21761 & 9953 & 14883 & 1292 & 903 \\
\hline $\begin{array}{l}\text { Kis-Balaton } \\
\text { Kis-Balaton } \\
\end{array}$ & 1623 & 2413 & 6659 & 8291 & 6196 & 2420 & 376 & 73 & 323 \\
\hline $\begin{array}{l}\text { Balaton, Keszthelyi-öböl } \\
\text { Lake Balaton Keszthelyi bay } \\
\end{array}$ & 0 & 0 & 0 & 0 & 0 & 0 & 0 & 0 & 0 \\
\hline $\begin{array}{l}\text { Kelet-Balaton } \\
\text { Lake Balaton-East }\end{array}$ & 86 & 97 & 220 & 505 & 736 & 305 & 470 & 260 & 72 \\
\hline $\begin{array}{l}\text { Tatai Öreg-tó } \\
\text { Old Lake at Tata }\end{array}$ & 0 & 0 & 0 & 21998 & 53013 & 15547 & 1740 & 0 & 2 \\
\hline $\begin{array}{l}\text { Velencei-tó és Dinnyési Fertő } \\
\text { Lake Velence and Dinnyési Fertő }\end{array}$ & 920 & 1700 & 5320 & 29614 & 19435 & 38948 & 4719 & 330 & 85 \\
\hline $\begin{array}{l}\text { Soponyai-halastavak } \\
\text { Fishponds at Soponya } \\
\end{array}$ & 1200 & 1120 & 4400 & 8081 & 1405 & 2212 & 118 & 2869 & 149 \\
\hline $\begin{array}{l}\text { Rétszilasi-halastavak } \\
\text { Fishponds at Rétszilas } \\
\end{array}$ & 1240 & 2400 & 2300 & 11721 & 1050 & 6717 & 572 & 316 & 345 \\
\hline $\begin{array}{l}\text { Dráva Barcs-Szentborbás } \\
\text { River Dráva: Barcs-Szentborbás }\end{array}$ & 0 & 0 & 0 & 0 & 0 & 0 & 0 & 0 & 0 \\
\hline $\begin{array}{l}\text { Pellérdi-halastavak } \\
\text { Fishponds at Pellérd } \\
\end{array}$ & 0 & 0 & 4 & 0 & 0 & 0 & 0 & 0 & 0 \\
\hline $\begin{array}{l}\text { Sumonyi-halastavak } \\
\text { Fishponds at Sumony }\end{array}$ & 0 & 0 & 1 & 32 & 1620 & 2150 & 430 & 140 & 4 \\
\hline $\begin{array}{l}\text { Duna Gönyü-Szob } \\
\text { River Danube: Gönyü - Szob }\end{array}$ & 0 & 0 & 0 & 0 & 140 & 6 & 2 & 25 & 0 \\
\hline $\begin{array}{l}\text { Duna Gemenc } \\
\text { River Danube at Gemenc } \\
\end{array}$ & 200 & 50 & 300 & 800 & 2000 & 5202 & 5202 & 350 & 0 \\
\hline $\begin{array}{l}\text { Duna Karapancsa } \\
\text { River Danube at Karapancsa } \\
\end{array}$ & 300 & 350 & 520 & 650 & 1172 & 1150 & 1050 & 680 & 150 \\
\hline $\begin{array}{l}\text { Kiskunsági szikes tavak } \\
\text { Natron lakes in Kiskunság }\end{array}$ & 454 & 30 & 467 & 23234 & 386 & 758 & 5003 & 3615 & 875 \\
\hline $\begin{array}{l}\text { Tömörkényi Csaj-tó } \\
\text { Lake Csaj at Tömörkény }\end{array}$ & 230 & 260 & 240 & 2478 & 5403 & 42 & 1820 & 2093 & 210 \\
\hline $\begin{array}{l}\text { Szegedi Fehér-tó és Fertő } \\
\text { Lake Fehér and Fertő at Szeged }\end{array}$ & 167 & 360 & 400 & 430 & 40 & 186 & 638 & 69 & 185 \\
\hline $\begin{array}{l}\text { Tisza-tó } \\
\text { Lake Tisza }\end{array}$ & 60 & 3100 & 3201 & 1400 & 850 & 350 & 1090 & 1200 & 640 \\
\hline $\begin{array}{l}\text { Hortobágy } \\
\text { Hortobágy }\end{array}$ & 7821 & 9490 & 16614 & 24589 & 8487 & 23575 & 35239 & 14822 & 3623 \\
\hline $\begin{array}{l}\text { Biharugrai és Begécsi halastavak } \\
\text { Fishponds at Biharugra and Begécs }\end{array}$ & 1570 & 2410 & 3539 & 21375 & 24198 & 16237 & 24762 & 7145 & 159 \\
\hline $\begin{array}{l}\text { Kardoskúti Fehér-tó } \\
\text { Lake Fehér at Kardoskút }\end{array}$ & 0 & 0 & 25 & 0 & 4500 & 4000 & 3000 & 2500 & 0 \\
\hline $\begin{array}{l}\text { Magyar or szág összesen } \\
\text { Hungary total }\end{array}$ & 16071 & 25480 & 47061 & 164881 & 152392 & 129758 & 101114 & 37779 & 7725 \\
\hline
\end{tabular}




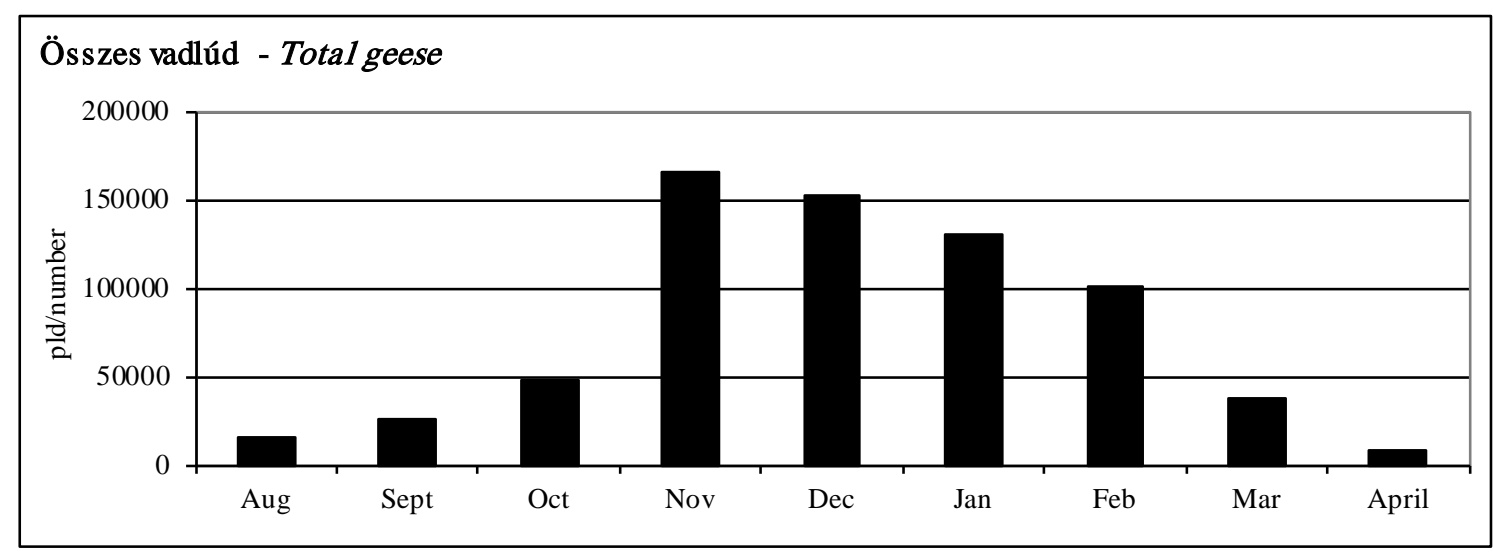

18. ábra: A vadludak összesített dinamikája Magyarországon, 2013/2014.

Figure 18: Dynamics of total geese in Hungary, 2013/2014.

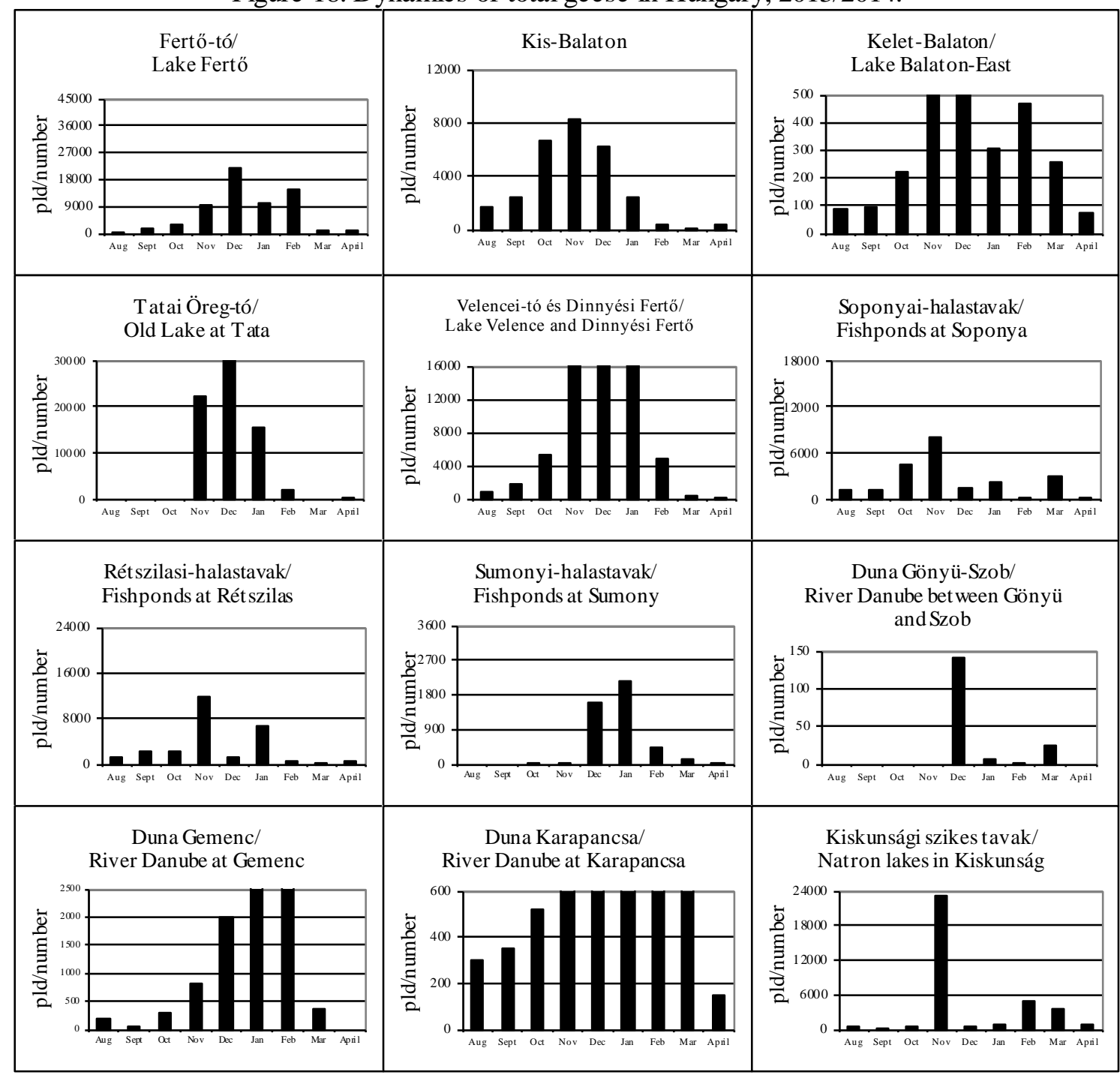

19. ábra: A vadludak összesített dinamikája Magyarországon, 2013/20134.

Figure 19: Dynamics of total geese in Hungary, 2013/2014. 


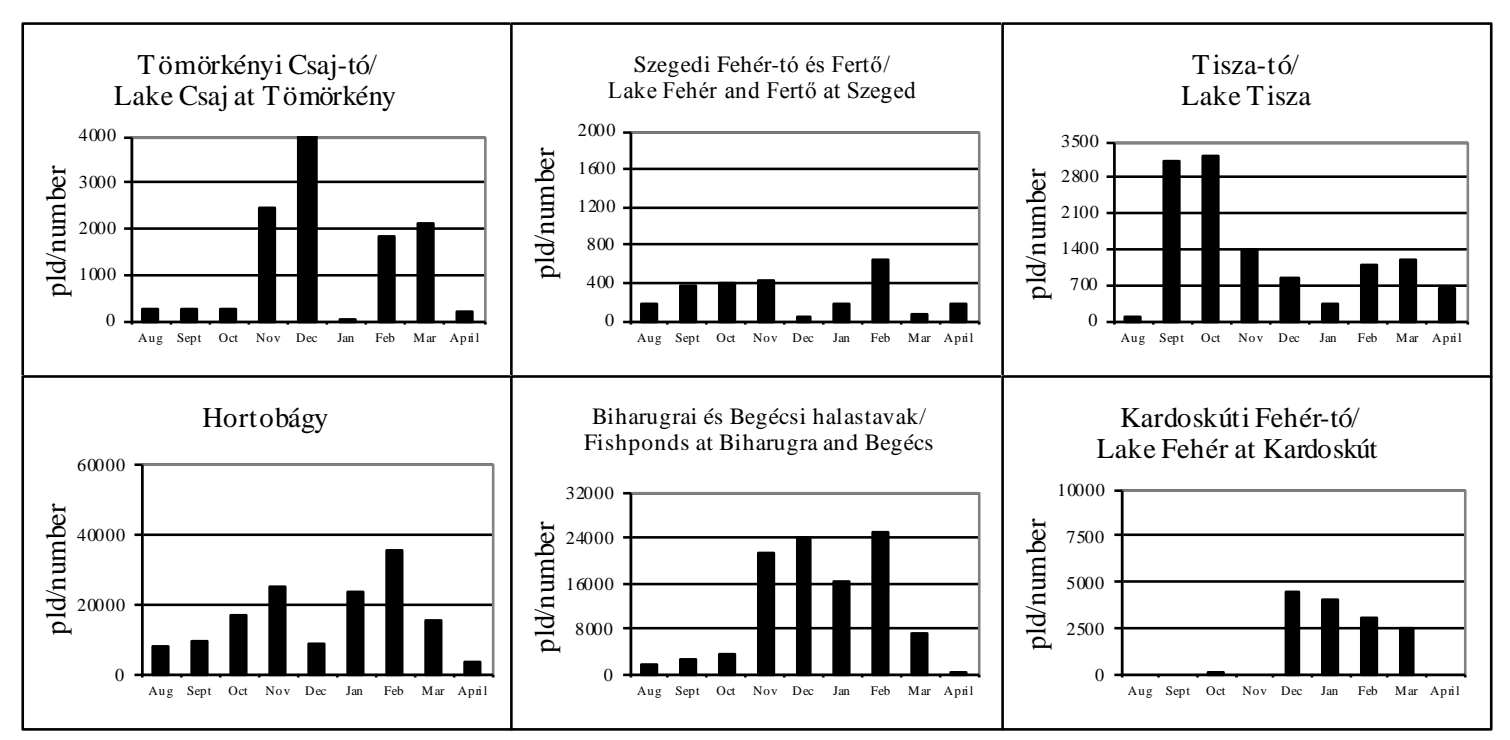

19. ábra: A vadludak összesített dinamikája Magyarországon, 2013/20134.

Figure 19: Dynamics of total geese in Hungary, 2013/2014. 

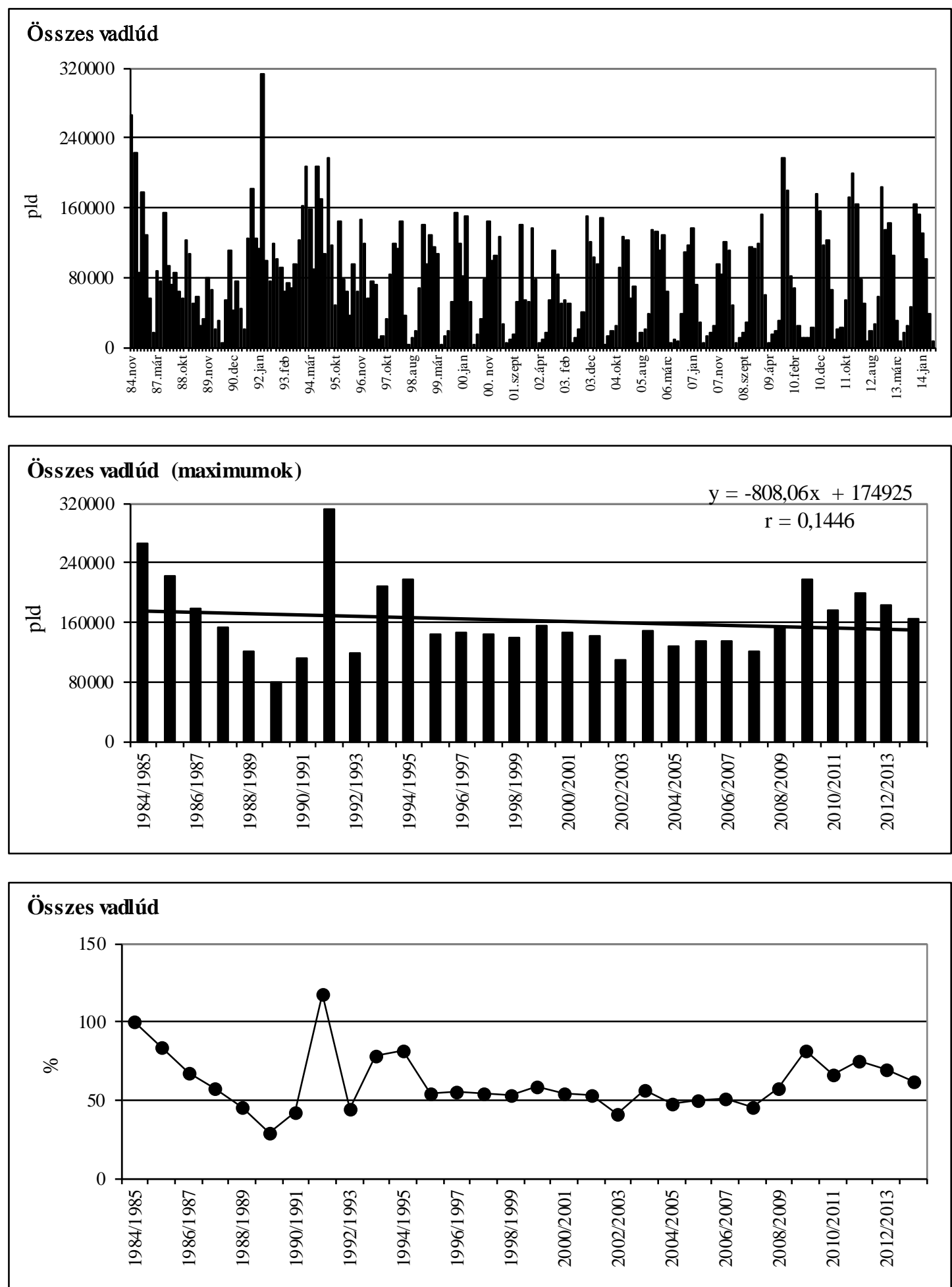

20. ábra: Az összes vadlúd havi dinamikája, éves maximumának trendje és éves maximum-indexe Magyarországon, 1984-2014

Figure 20: Monthly dynamics, trend of yearly maximums and maximum indices for total goose species in Hungary, 1984-2014 


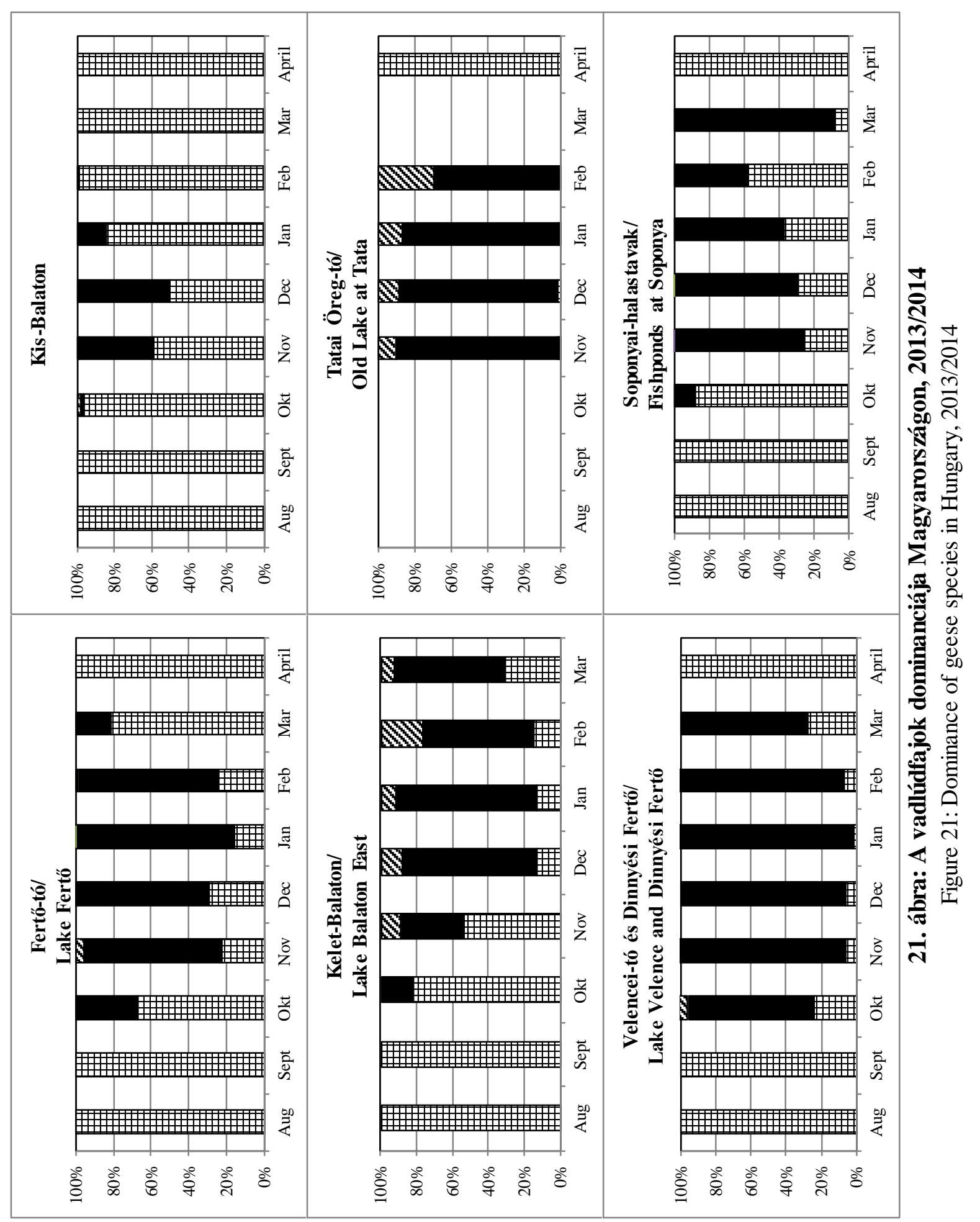




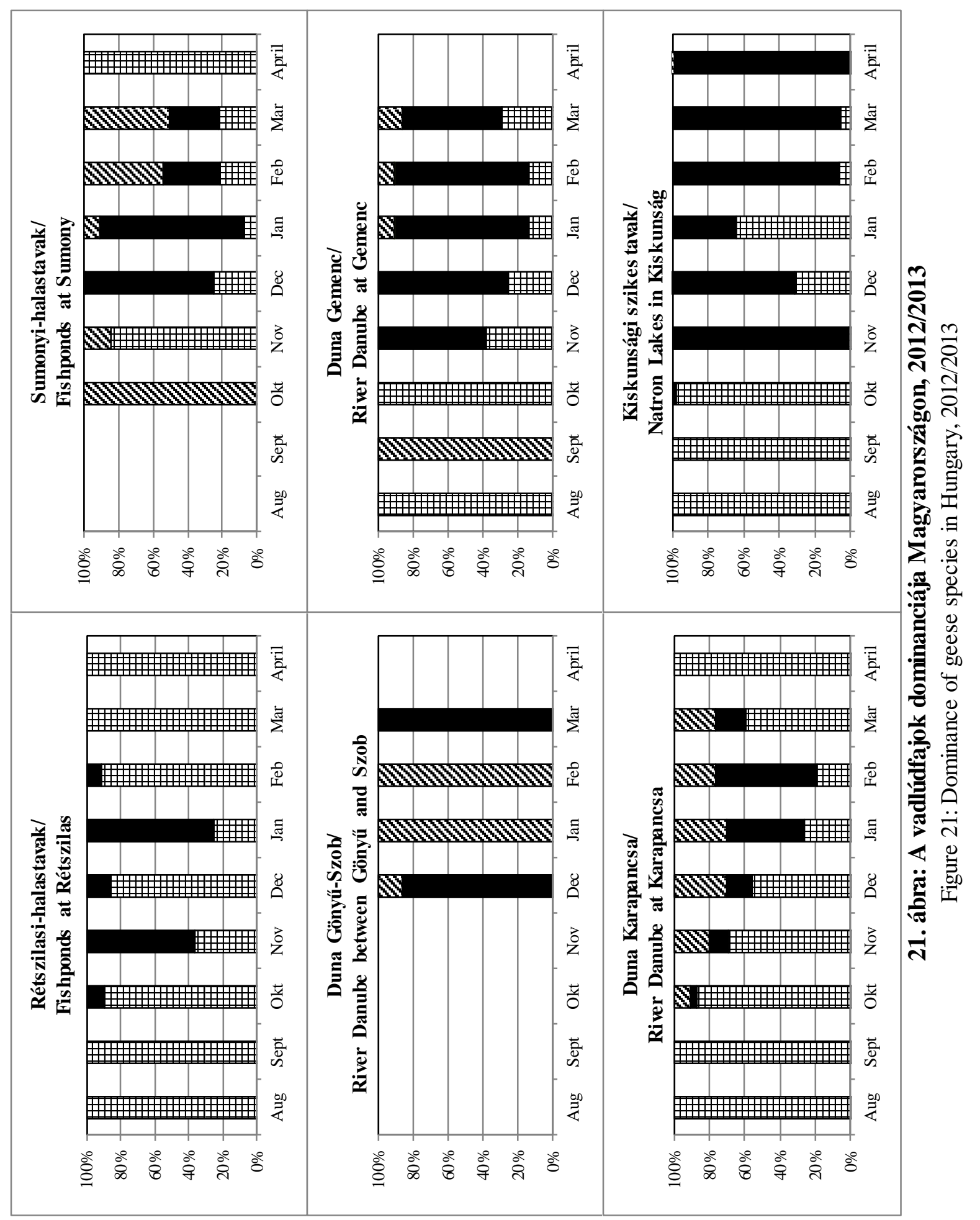




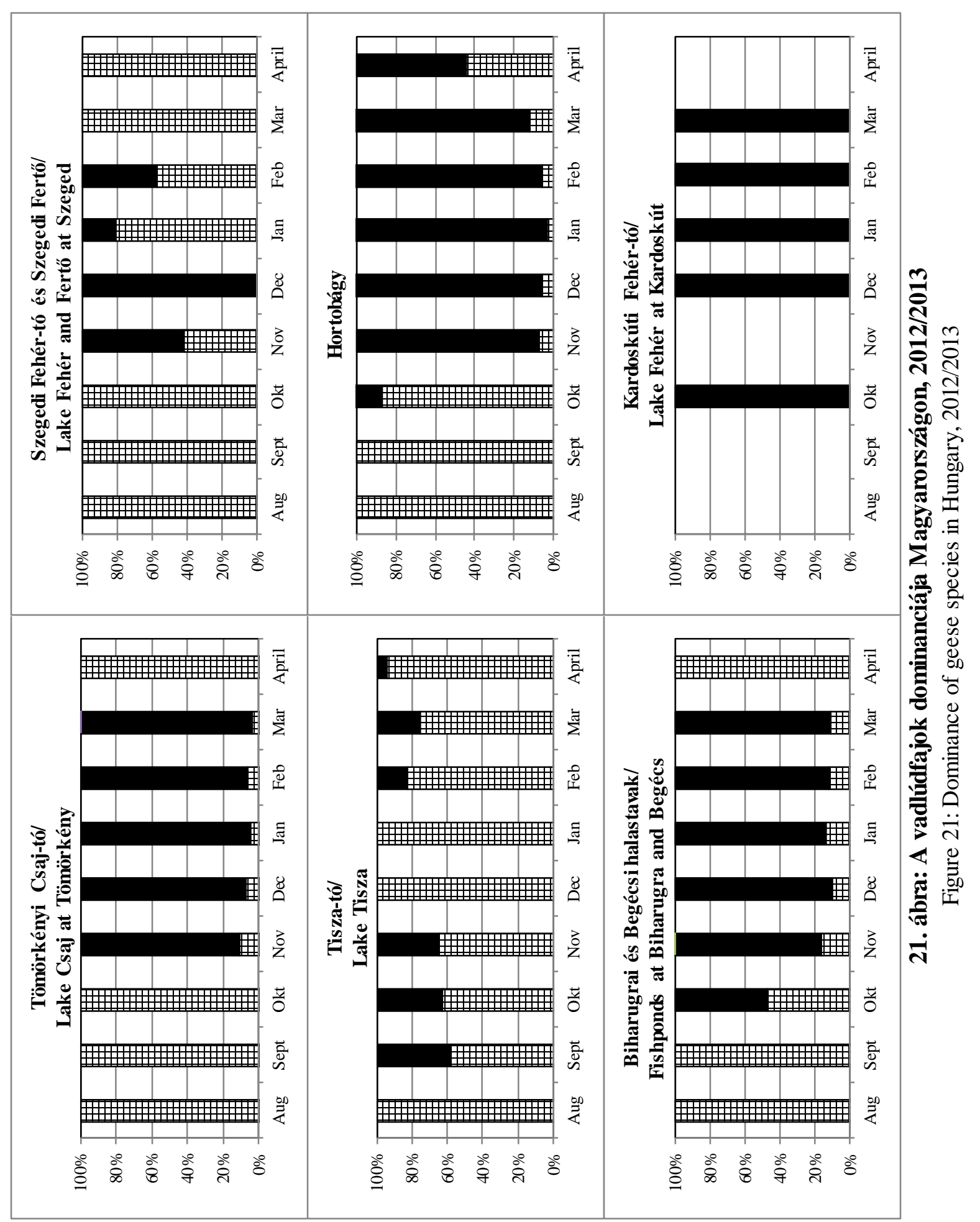


32. táblázat: A vadludak dinamikája és dominanciája Magyarországon, 2013/2014.

Table 32: Dynamics and dominance of geese in Hungary, 2013/2014.

\begin{tabular}{|c|c|c|c|c|c|c|c|c|c|c|c|c|}
\hline \multirow[b]{2}{*}{ Time } & Ans ans & Ans alb & Ans fab & Ans ery & Egy éb & Total & Ans ans & Ans alb & Ans fab & Ans ery & Egy éb & Total \\
\hline & \multicolumn{6}{|c|}{$\begin{array}{ll}\text { Number of geese } \\
\end{array}$} & \multicolumn{6}{|c|}{$\%$ of geese } \\
\hline 2013.Aug & 16071 & 0 & 0 & 0 & 0 & 16071 & 100 & 0 & 0 & 0 & 0 & 100 \\
\hline 2013.Sept & 24130 & 1300 & 50 & 0 & 0 & 25480 & 95 & 5 & 0 & 0 & 0 & 100 \\
\hline 2013.Okt. & 35573 & 11027 & 453 & 0 & 8 & 47061 & 76 & 23 & 1 & 0 & 0 & 100 \\
\hline 2013.Nov & 23110 & 138862 & 2811 & 8 & 90 & 164881 & 14 & 84 & 2 & 0 & 0 & 100 \\
\hline 2013.Dec & 18180 & 127530 & 6630 & 5 & 47 & 152392 & 12 & 84 & 4 & 0 & 0 & 100 \\
\hline 2014.Jan & 11848 & 114558 & 3188 & 21 & 143 & 129758 & 9 & 88 & 2 & 0 & 0 & 100 \\
\hline 2014.Feb & 12516 & 86688 & 1743 & 61 & 106 & 101114 & 12 & 86 & 2 & 0 & 0 & 100 \\
\hline 2014.Mar & 6135 & 31281 & 300 & 1 & 62 & 37779 & 16 & 83 & 1 & 0 & 0 & 100 \\
\hline 2014.Apr & 4796 & 2916 & 13 & 0 & 0 & 7725 & 62 & 38 & 0 & 0 & 0 & 100 \\
\hline
\end{tabular}

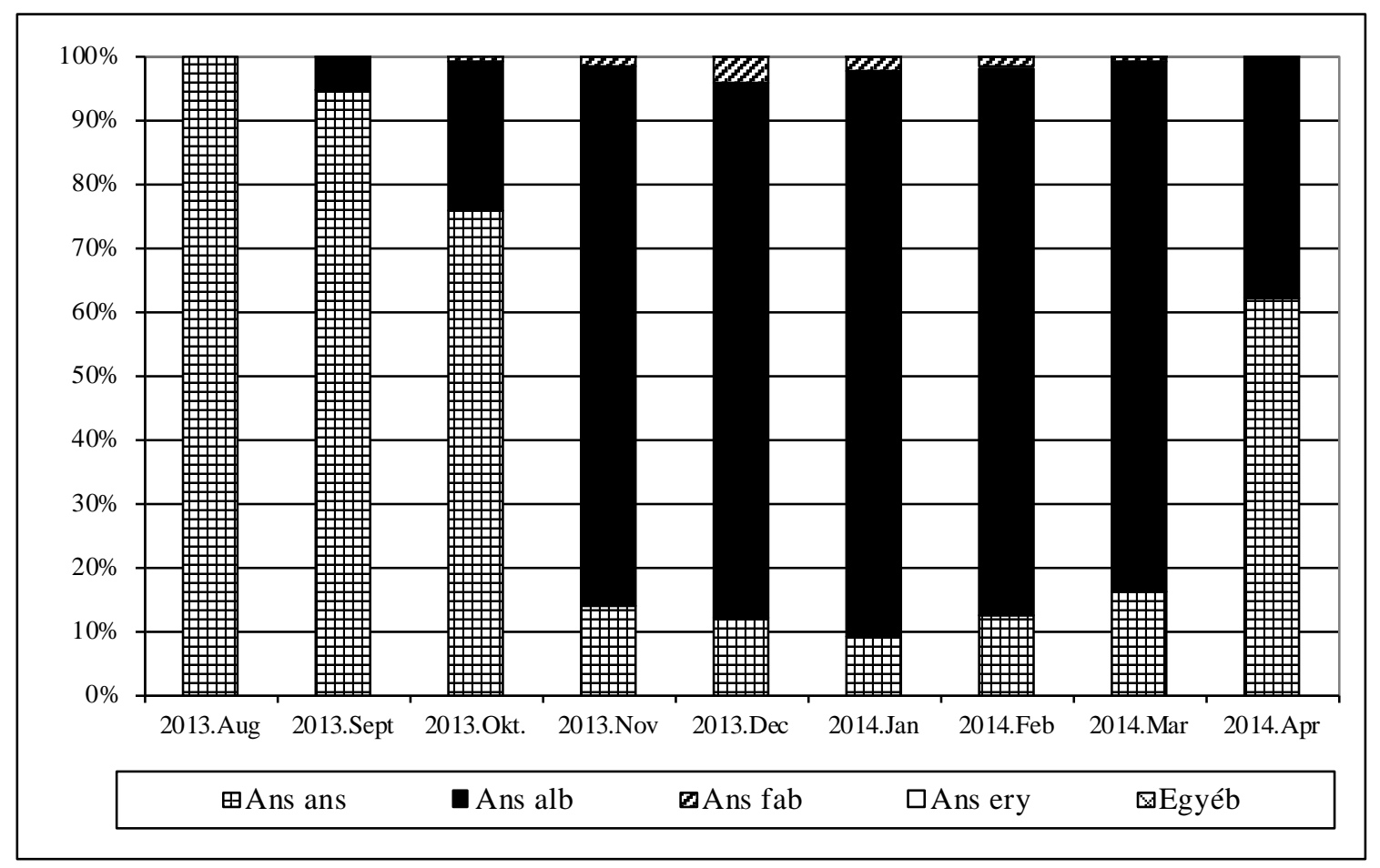

22. ábra: A vadlúdfajok dominanciája Magyarországon, 2013/2014.

Figure 22: Dominance of geese in Hungary in the season 2013/2014. 